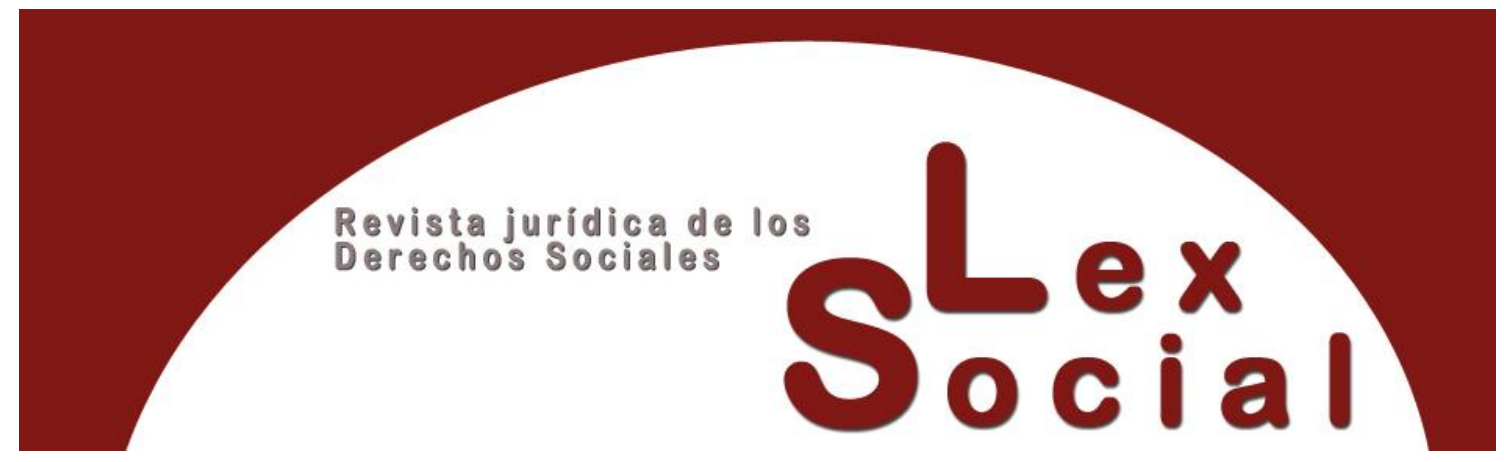

\title{
EL DERECHO A LAS PRESTACIONES POR DESEMPLEO DE LAS PERSONAS INMIGRANTES
}

\section{THE RIGHT TO UNEMPLOYMENT BENEFITS FOR IMMIGRANTS}

BELÉN DEL MAR LÓPEZ INSUA

Profesora Titular de Derecho del Trabajo y de la Seguridad Social

Universidad de Granada

http://orcid.org/0000-0002-1248-6015

Cómo citar este trabajo: López Insúa, B. (2021). El derecho a las prestaciones por desempleo de las personas inmigrantes. Lex Social: Revista De Derechos Sociales, 11(1), 138-207 https://doi.org/10.46661/lexsocial.5473

\section{RESUMEN}

La protección por desempleo de trabajadores inmigrantes ha sido una de las cuestiones más discutidas a nivel doctrinal y jurisprudencial. A este respecto, el artículo 36.5 de la Ley Orgánica Española de Extranjería (tras la reforma operada por la LO 2/2009) dispone que el trabajador extranjero en situación de irregularidad podrá optar por no invalidar el contrato de trabajo, aunque quede -de manera ilógicaexcluido de la posibilidad de obtener la prestación por desempleo. Esta realidad normativa plasma una cierta idea de justicia distributiva que contradice, claramente, lo dispuesto por la Organización Internacional del Trabajo para la protección multinivel de los derechos fundamentales y de atención social pública a las personas migrantes. Actualmente se reclama el establecimiento de un sistema de rentas básicas que afronte la continuidad de las rentas de trabajadores inmigrantes, en períodos transicionales, para así garantizar el derecho a una existencia digna de todas las personas en riesgo de exclusión social. Ahora bien, para que pueda operar esta medida se precisa superar primero los límites que a la nacionalidad se imponen por la Ley Orgánica de Extranjería en España, así como por la doctrina del Tribunal Supremo. 
Palabras Clave: desempleo, rentas mínimas, ingreso mínimo vital, inmigración y protección.

\begin{abstract}
Unemployment protection for immigrant workers has been one of the most controversial issues at the doctrinal and jurisprudential level. In this regard, article 36.5 of the Spanish Organic Law on Foreigners (after the reform operated by the LO 2/2009) provides that foreign workers in an irregular situation may choose not to invalidate the employment contract, even if it remains -in an illogical wayexcluded from eligibility for unemployment benefit. This normative reality reflects a certain idea of distributive justice that clearly contradicts the provisions of the International Labour Organization for the multi-level protection of fundamental rights and public social care for migrants. At present, there is a call for the establishment of a system of basic incomes that addresses the continuity of the incomes of immigrant workers, in transitional periods, in order to guarantee the right to a dignified existence for all people at risk of social exclusion. However, in order for this measure to operate, it is first necessary to exceed the limits imposed on nationality by the Organic Law on Foreigners in Spain, as well as by the doctrine of the Supreme Court.
\end{abstract}

KEYWORDS: unemployment, minimum income, minimum living income, immigration and protection.

\title{
SUMARIO
}

I. Precariedad laboral y desprotección social de inmigrantes: un marco insuficiente para la garantía de un derecho a la igualdad de trato

II. Seguridad Social de los trabajadores inmigrantes: especial referencia a la protección por desempleo

1. Marco normativo regulador: universalidad versus desprotección social

2. La protección por desempleo de los inmigrantes

2.1. El acceso a las prestaciones por desempleo de los trabajadores inmigrantes regulares

2.2. Un constante tira y afloja: la exclusión de los trabajadores inmigrantes irregulares de la protección por desempleo

2.3. Nivel asistencial y desprotección de los trabajadores inmigrantes

\subsubsection{El Nivel asistencial básico}

2.3.2. Rentas activas de inserción y retorno de trabajadores inmigrantes: ¿ilusión o realidad?

3. Rentas mínimas a nivel autonómico y propuestas de lege ferenda 
III. Alusión a una nueva prestación no contributiva: el Ingreso Mínimo Vital. Límites aplicativos y exclusión de inmigrantes irregulares

IV. Conclusiones

Bibliografía

"... para poder mirar al futuro, hay que tener ojos adecuados; los ojos de ciertas personas, sin embargo, son tan torpes que no alcanzan más allá del presente, y en otros nuevamente la voluntad es tan débil que no pueden resistir la tentación de sacrificar el futuro al momento"

VON IHERING, $\mathrm{R}^{1}$

\section{PRECARIEDAD LABORAL Y DESPROTECCIÓN SOCIAL DE INMIGRANTES: UN MARCO INSUFICIENTE PARA LA GARANTÍA DE UN DERECHO A LA IGUALDAD DE TRATO}

Los incesantes movimientos migratorios de trabajadores en el mercado interior europeo en busca de nuevas oportunidades de vida y trabajo, viene ocupando desde hace tiempo un lugar primordial entre las cuestiones que más preocupan a la ciudadanía. Es harto significativo que esta materia figure como elemento clave y fundamental en la agenda de la Unión para alcanzar el grado óptimo de desarrollo económico, de cohesión e integración social que tanto necesita el conjunto de Estados miembros. No obstante, a pesar del intenso debate que todo esto ha generado, lo cierto es que la respuesta que han otorgado los distintos Estados miembro ha sido muy dispar². Lo que hace plantear ciertas dudas en torno al concepto de ciudadanía inclusiva que tanto se predica desde el ámbito de la Unión Europea.

En efecto, la relación entre inmigración y ciudadanía no debe nunca deslindarse de la garantía misma de los derechos fundamentales y, por lo que aquí interesa, del respeto a los derechos de Seguridad Social de las personas inmigrantes. Se parte del respeto al principio de igualdad real de trato en la atribución de tales derechos, y, lógicamente, contrarrestando las tendencias recientes a la reducción de los estándares que trabajosamente han venido alcanzándose. Y es que, como bien indica la doctrina científica, una "ciudadanía inclusiva" ha de sustentarse en el pleno reconocimiento de todos los derechos fundamentales. De lo contrario, los derechos sociales pasarán de ser pieza elemental para la construcción de un concepto de ciudadanía inclusiva ${ }^{3}$ a convertirse en arma arrojadiza para la mercantilización de las relaciones laborales, la desregulación de las condiciones de trabajo y la desprotección social.

\footnotetext{
${ }^{1}$ Von Ihering, Rudolf: El fin en el Derecho, Estudio Preliminar "El pensamiento jurídico de Ihering y la dimensión funcional del Derecho”, a cargo de Monereo Pérez, J.L., Comares, Granada, 2011, pág. 71.

${ }^{2}$ López Insua, Belén del Mar: "La protección frente al desempleo de las personas emigrantes de la Unión Europea" en VV.AA., Fernández Avilés, José Antonio (Dir) y Durán Bernardino, Manuela (Coord)., Nuevas políticas jurídicas para el cambio migratorio. Tutela jurídico-social de los trabajadores emigrantes, Navarra, Aranzadi, 2017, págs. 573-575.

3 Monereo Pérez, José Luis: "Los derechos de Seguridad Social de los trabajadores migrantes: inmigración laboral y refugiados", Revista de Derecho Migratorio y Extranjería, nº41, 2016, pág. 8 en su versión digital. 
En los países de la Unión y, en particular en España, la inmigración continúa siendo uno de las cuestiones sociales que más atención ha acaparado en los distintos medios de comunicación y ello es porque, ciertamente, constituye esta región natural receptora de constantes flujos migratorios. Principalmente esta problemática se ha visto acrecentada a causa de la grave coyuntura de crisis económica que, desde el 2008, viene implacable fustigando a las frágiles estructuras de todos los mercados nacionales, incluido el español. La gravedad y universalidad del problema han planteado algunos interrogantes acerca de la adaptación de los sistemas europeos de Seguridad Social. Este hecho determina que la coordinación de la Seguridad Social Europea sea ahora más necesaria si cabe que nunca. La coordinación instrumental (no armonización legislativa, pues su finalidad no es establecer un sistema normativo comunitario de Seguridad Social) de los distintos sistemas de Seguridad Social supone la traslación a este ámbito del derecho a la libre circulación de trabajadores, en los términos que fijan los artículos 45 y siguientes del Tratado de Funcionamiento de la Unión Europea (TFUE) para los trabajadores migrantes comunitarios. Esto se traduce, paradigmáticamente, en el derecho a circular libremente por la Unión Europea conservando los derechos adquiridos en materia de Seguridad $\mathrm{Social}^{4}$, con el consiguiente derecho a exportar las prestaciones, sin que la legislación del Estado miembro que reconoció una prestación pueda condicionar su disfrute a la residencia o permanencia en el territorio de dicho Estado $^{5}$.

\footnotetext{
4 Monereo Pérez, José Luis: "Los derechos de Seguridad Social de los trabajadores migrantes: inmigración laboral y refugiados"...op.cit., pág. 13

${ }^{5}$ López Insua, Belén del Mar: "La protección frente al desempleo de las personas emigrantes de la Unión Europea"...op.cit., págs. 573 y siguientes. A este respecto, cabe cita la Sentencia del Tribunal de Justicia (Sala Tercera) de 18 de diciembre de 2019, Asunto C-447/18. Procedimiento prejudicial - Seguridad social - Coordinación de los sistemas de seguridad social — Reglamento (CE) n. ${ }^{\circ}$ 883/2004 — Artículo 3 - Ámbito de aplicación material - Prestación de vejez — Libre circulación de los trabajadores en la Unión Europea - Reglamento (UE) n. ${ }^{\circ}$ 492/2011 - Artículo 7 - Igualdad de trato entre los trabajadores nacionales y los inmigrantes - Ventajas sociales - Legislación de un Estado miembro que reserva la concesión de una "prestación a los representantes deportivos" exclusivamente a los ciudadanos de ese Estado.

Resulta importante destacar la siguiente interpretación que realiza el TJUE al principio de igualdad de trato entre extranjeros y nacional en relación al percibo de una ventaja social: "... el objetivo de igualdad de trato promovido por el artículo 7, apartado 2, del Reglamento n. ${ }^{\circ}$ 492/2011 que el concepto de «ventaja social» comprende todas las ventajas que, vinculadas o no a un contrato de trabajo, se reconocen generalmente a los trabajadores nacionales principalmente por razón de su condición objetiva de trabajadores o por el mero hecho de su residencia habitual en territorio nacional, y cuya extensión a los trabajadores nacionales de otros Estados miembros permite, por lo tanto, facilitar su movilidad en el interior de la Unión (véanse, en este sentido, las sentencias de 17 de abril de 1986, Reed, 59/85, EU:C:1986:157, apartado 26; de 12 de mayo de 1998, Martínez Sala, C-85/96, EU:C:1998:217, apartado 25, y de 15 de septiembre de 2005, Ioannidis, C-258/04, EU:C:2005:559, apartado 35) y, por lo tanto, su integración en el Estado miembro de acogida.

Como ya ha declarado el Tribunal de Justicia, son ventajas de ese tipo, entre otras, un subsidio de desempleo destinado a los jóvenes que acaban de terminar sus estudios y que están buscando su primer empleo (véase, en este sentido, la sentencia de 15 de septiembre de 2005, Ioannidis, C-258/04, EU:C:2005:559, apartado 34), una prestación de crianza para el hijo de un trabajador (véase, en este sentido, la sentencia de 12 de mayo de 1998, Martínez Sala, C-85/96, EU:C:1998:217, apartado 26), la facultad de la viuda y los hijos menores de un trabajador inmigrante de beneficiarse de los descuentos sobre el precio del transporte establecidos en favor de las familias numerosas (véase, en este sentido, la sentencia de 30 de septiembre de 1975, Cristini, 32/75, EU:C:1975:120, apartado 13), la facultad de un ISSN: 2174-6419 Lex Social, vol. 11, núm. 1 (2021)
} 
Sin embargo, la cosa cambia sustancialmente cuando se trata de inmigrantes extracomunitarios en situación irregular. Y ello es porque no existe una identidad perfecta entre la situación reguladora de las políticas de inmigración y el derecho al acceso a determinadas prestaciones del sistema de Seguridad Social. Por lo que, al término, el trabajador extranjero irregular que no cumpla con las condiciones que establece la legislación española (en concreto, con la autorización pertinente para residir y trabajar ${ }^{6}$ se verá abocado a sufrir un debilitamiento en su estatus laboral y de ciudadanía social ${ }^{7}$.

Lamentablemente, en este punto, la protección por desempleo ha sido y está siendo muy problemática $^{8}$. Lo que plasma una cierta idea de justicia distributiva que contradice, claramente, lo dispuesto por la Organización Internacional del Trabajo para la protección multinivel de los derechos fundamentales y de atención social pública a las personas migrantes ${ }^{9}$. En este sentido, todos los Estados deberán adoptar medidas sostenibles y adaptadas a las circunstancias nacionales, con inclusión de "la ampliación de la Seguridad Social a todas las personas, incorporando medidas para proporcionar ingresos básicos a quienes necesiten esa protección, y la adaptación de su alcance y cobertura para responder a las nuevas necesidades e incertidumbres generadas por la rapidez de los cambios tecnológicos, sociales, demográficos y económicos"10. De igual modo, cabe tener en cuenta otros textos a nivel internacional y comunitario, a saber: el artículo 22 de la Declaración Universal de los Derechos del Hombre de 1948, en donde se reconoce el derecho de toda persona, en cuanto miembro de la sociedad, al derecho a la Seguridad Social. De igual modo, el artículo 9 del Pacto Internacional de los

inculpado que tiene la condición de trabajador de utilizar una de las lenguas disponibles para los residentes de un municipio del Estado miembro de acogida (véase, en este sentido, la sentencia de 11 de julio de 1985, Mutsch, 137/84, EU:C:1985:335, apartados 16 y 17), o la posibilidad de obtener autorización para que la pareja de un trabajador, sin estar casada con él ni ser nacional del Estado miembro de acogida, pueda residir con él en dicho Estado (véase, en este sentido, la sentencia de 17 de abril de 1986, Reed, 59/85, EU:C:1986:157, apartado 28), ya que todas estas medidas pueden contribuir a la integración del trabajador inmigrante en el país de acogida y, por consiguiente, a lograr el objetivo de la libre circulación de los trabajadores.

Con el mismo espíritu, debe reconocerse que la posibilidad de que se recompense a un trabajador inmigrante, en las mismas condiciones que a los trabajadores nacionales del Estado miembro de acogida, por sus logros deportivos excepcionales en representación de dicho Estado miembro, o de sus predecesores legales, puede contribuir a la integración de dicho trabajador en dicho Estado miembro y, por lo tanto, a que se alcance el objetivo de la libre circulación de trabajadores".

${ }^{6}$ González Ortega, Santiago: "El derecho de los extranjeros extracomunitarios en situación irregular a prestaciones de Seguridad Social derivadas de contingencias comunes", en VV.AA., González Ortega, Santiago (Coord)., La protección social de los extranjeros en España, Valencia, Tirant Lo Blanch, 2010, pág. 241.

${ }^{7}$ Cabeza Pereiro, Jaime: Ensayo sobre el trabajo precario y las personas vulnerables, Murcia, Laborum, 2015, pág. 45.

${ }^{8}$ Márquez Prieto, Antonio: La protección por desempleo en España y otros Estados europeos, Madrid, Ministerio de trabajo e Inmigración, 2001.

${ }^{9}$ Monereo Pérez, José Luis: "Artículo 53. Nivel de protección", en VV.AA., Monereo Atienza, Cristina y Monereo Pérez, José Luis (Dir y Coord)., La Europa de los derechos. Estudio sistemático de la Carta de los Derechos Fundamentales de la Unión Europea, Granada, Comares, 2012, págs. 1404-1406.

${ }^{10}$ Declaración de la Organización Internacional del Trabajo sobre la justicia social para una globalización equitativa, adoptada por la Conferencia Internacional del Trabajo en su nonagésima séptima reunión, Ginebra, 10 de junio de 2008, página 10. 
Derechos Económicos, Sociales y Culturales establece que los Estados partes en el presente pacto, reconocen el derecho de toda persona a la Seguridad Social, incluso al Seguro social. Por su parte, la Carta Social Europea de 1961 prevé el derecho a la Seguridad Social de los trabajadores y de las personas a su cargo (artículo 12) y el derecho a la asistencia social y médica a toda persona que carezca de recursos suficientes (artículo 13).

En definitiva, el derecho a la protección social se extiende con carácter general a todas las personas (incluidas las inmigrantes), lo que incluye el acceso a la asistencia social ${ }^{11}$. De acuerdo con este acervo normativo internacional y no comunitario, no cabe limitar el disfrute efectivo de los derechos de Seguridad Social de las personas que se desplazan o circulan para trabajar. De ahí que deba superarse esa distinción entre inmigrantes regulares e irregulares para decidir si otorgar o no el disfrute de los derechos de protección social. No tiene sentido (desde una lógica de justicia social) seguir concediendo esa relevancia a las "técnicas de control" de los flujos migratorios frente a las "técnicas de garantía" del derecho social fundamental a la Seguridad Social ${ }^{12}$.

En relación con el desempleo -y en este contexto crítico-, la protección en materia de Seguridad Social se ve desvirtuada y desnaturalizada, pues no cumple con el objetivo mismo de garantía multinivel de las políticas activas y de desarrollo pro-activo de las políticas pasivas en caso de estado de necesidad. Y ello es porque en todo Estado Social -de fomento del derecho a un ciudadanía inclusiva- se ha de garantizar el acceso de todas las personas, en igualdad de condiciones, a la vida: política, económica, cultural y social (artículo 9.2 de la Constitución Española- CE-). Al hilo de esta idea, los derechos al pleno empleo (artículo 40 de la CE) y a la atención "... para todos los ciudadanos que garantice una protección social suficiente frente a las situaciones de necesidad, especialmente, en caso de desempleo" (artículo 41 de la CE), se erigen en piezas esenciales para la protección de los derechos de Seguridad Social ${ }^{13}$ inherentes al estatus de todo trabajador. De ahí que los poderes públicos hayan de insistir en pro a su cumplimiento $\mathrm{y}$, sin distinciones, para el caso de trabajadores inmigrantes que desarrollan una actividad profesional en España ${ }^{14}$.

\footnotetext{
${ }^{11}$ Rubio Velasco, Fuencisla: "Capítulo VIII. La prestación por desempleo de los extranjeros irregulares", en VV.AA., Rodríguez Iniesta, Guillermo y Sánchez-Rodas Navarro, Cristina (Coord)., La protección por desempleo en España. XII Congreso Nacional de la Asociación Española de Salud y Seguridad Social (AESSS), Murcia, Laborum, 2015, pág. 263.

12 Monereo Pérez, José Luis: "Los derechos de Seguridad Social de los trabajadores migrantes: inmigración laboral y refugiados"...op.cit., pág. 13

${ }^{13}$ Monereo Pérez, José Luis: "El derecho a la Seguridad Social", en VV.AA., Monereo Pérez, José Luis; Molina Navarrete, Cristóbal y Moreno Vida, $\mathrm{M}^{\mathrm{a}}$ Nieves (Dirs)., Comentario a la Constitución socioeconómica de España, Granada, Comares, 2002, págs. 1425 y siguientes.

${ }^{14}$ En esta línea, se pronuncia el artículo 2 del Real Decreto Legislativo 3/2015, de 23 de octubre, por el que se aprueba el texto refundido de la Ley de Empleo. En concreto, se indica que: "Son objetivos generales de la política de empleo.... b) Mantener un sistema eficaz de protección ante situaciones de desempleo, que comprende las políticas activas de empleo y las prestaciones por desempleo, asegurando la coordinación entre las mismas y la colaboración entre los distintos entes implicados en la ejecución de la política de empleo y su gestión y la interrelación entre las distintas acciones de intermediación laboral". ISSN: 2174-6419 Lex Social, vol. 11, núm. 1 (2021)
} 
En la actualidad, la evolución del sistema de Seguridad Social tiende hacia el carácter de "universalidad subjetiva"- esto es, la cobertura de toda la población-, aunque lo cierto es que no termina de ser completada para todo tipo de prestaciones satisfechas por el sistema de Seguridad Social y para todas las personas, lo que evidencia ritmos o niveles de protección distintos dentro del mismo sistema ${ }^{15}$. La dialéctica entre el establecimiento de un sistema "universalista" o de "ciudadanía"/"nacional" (vinculada a la nacionalidad del trabajador) constituye eje fundamental para el reconocimiento de los derechos de protección social. Ni el programa Constitucional abierto que establece el artículo $41^{16}$, ni los textos normativos internacionales y comunitarios pueden favorecer y/o limitar la fijación de un estatuto de ciudadanía laboral y de protección social infraconstitucional para los trabajadores inmigrantes en base al requisito de la nacionalidad $^{17}$.

\section{SEGURIDAD SOCIAL DE LOS TRABAJADORES INMIGRANTES: ESPECIAL REFERENCIA A LA PROTECCIÓN POR DESEMPLEO}

La publicación de la Ley Orgánica 4/2000, de 11 de enero, sobre Derechos y Libertades de los extranjeros en España y su integración social (LOEXIs) ${ }^{18}$ supuso una importante novedad para el ordenamiento jurídico español, pues gracias a ésta se pusieron en marcha nuevas políticas de integración de inmigrantes ${ }^{19}$, aparte de una ampliaron en los derechos de los inmigrantes y un establecimiento, como principio eje para el desarrollo de la política social, del derecho de igualdad de trato entre españoles y extranjeros. Sin embargo, antes de entrar en materia de Seguridad Social, conviene precisa que para que opere esa hipotética igualdad, primero habrá de concretar cuál es la diferencia entre extranjero e inmigrante.

Desde un punto de vista jurídico, el concepto de "extranjería" se refiere a aquellos individuos que carecen de la nacionalidad española y que adquieren su significado en relación a la realidad socio-política de un Estado soberano, en este caso: España. La definición de extranjero aparece delimitada, en sentido negativo, por la LOEXIs en su

\footnotetext{
${ }^{15}$ Monereo Pérez, José Luis; Molina Navarrete, Cristóbal; Quesada Segura, Rosa y Maldonado Molina, Juan Antonio: Manual de Seguridad Social, Decimoquinta edición, Madrid, Tecnos, 2019, págs. 63-65.

16 Se trata éste de un derecho de configuración legal y de aplicación progresiva, en virtud de las posibilidades económicas del sistema, tal y como ha puesto de relieve la jurisprudencia del Tribunal Constitucional. Ver Monereo Pérez, José Luis: "El derecho a la Seguridad Social"...op.cit., págs. 1430 y siguientes.

${ }^{17}$ Fernández Avilés, José Antonio: "Los "renglones torcidos" de la política jurídica de protección por desempleo del trabajador extranjero inmigrante", Revista de Derecho Migratorio y Extranjería, núm. 31, 2012, págs. 1 y 2 en su versión digital.

${ }^{18} \mathrm{Su}$ actual Reglamento de desarrollo fue aprobado por el Real Decreto 557/2011, de 20 de abril (BOE de 30 de abril), el cual derogó al Real Decreto 2393/2004, de 30 de diciembre.

19 Sánchez Jiménez, Ma Ángeles: "La articulación del derecho de extranjería", en VV.AA., Sánchez Jiménez, Ma Ángeles (Coord)., Derecho de extranjería: un análisis legal y jurisprudencial del régimen jurídico del extranjero en España (jurisprudencia y formularios), Murcia, DM, 2005, pág. 96. 
artículo 1.1 al indicar que: "Se consideran extranjeros, a los efectos de la aplicación de la presente Ley, a los que carezcan de la nacionalidad española".

La extranjería constituye aquí una situación jurídica diferencial que marca las fronteras entre el ciudadano nacional y el no nacional (extranjero). Las principales limitaciones se manifiestan en torno a la titularidad y el ejercicio de los derechos que, como consecuencia del estatuto jurídico de extranjería, pueden disfrutar los no nacionales. Resulta curioso que, desde la lógica jurídica, el elemento de "extranjería" instituya la razón de ser de la discriminación y, por tanto, de la distinción entre ambos colectivos ${ }^{20}$. Empero, en algunos ordenamientos jurídicos (de tinte universalista) se ha alzado como valor central la dignidad de la persona ${ }^{21}$, de ahí que se haya extendido el principio de equiparación entre nacionales y extranjeros en la titularidad y ejercicio de los derechos. Por más que se intentan reducir al mínimo las divergencias entre derechos, lo cierto es que todavía persisten limitaciones que arrojan a los extranjeros a sufrir cierta precariedad y vulnerabilidad $^{22}$.

Aunque el artículo 13 de la CE indique que " Los extranjeros gozarán en España de las libertades públicas que garantiza el presente Título en los términos que establezcan los tratados y la ley", lo cierto es que, en términos comparados, una de las principales limitaciones que se producen entre nacionales y extranjeros es la referente al acceso a derechos sociales y laborales, con motivo de la libertad de residencia y/o establecimiento, como filtro para la inserción estable del extranjero en el país (por regla general, éste necesita de visado para entrar en un país que no es el suyo; permiso de residencia y/o trabajo para permanecer y residir en él). En particular, esta restricción es la que determina el estatuto jurídico básico de la extranjería en España ${ }^{23}$ : entrada (a través de visado como elemento básico de control), permanencia (mediante autorización de residencia), trabajo (igualmente mediante la concesión de una autorización) y, finalmente, el régimen sancionador. Este estatuto jurídico básico es el que permite distinguir entre extranjeros regulares e irregulares. Evidentemente, la posibilidad de

\footnotetext{
${ }^{20}$ Ruiz de Huidobro de Carlos, José María: "La ley Orgánica 4/2000: historia de un desencuentro y razón de su desenfoque jurídico", Migraciones. Revista del Instituto Universitario de Estudios sobre Migraciones, nº7, 2000, pág. 62.

${ }^{21}$ Monereo Pérez, José Luis: La dignidad del trabajador. Dignidad de la persona en el sistema de Relaciones Laborales, Murcia, Laborum, 2020.

22 Taribini-Castellani Aznar, Margarita: "Los derechos de los trabajadores extranjeros: Puntos críticos", Revista del Ministerio de Trabajo y Asuntos Sociales, n63, 2006, págs. 198-201. Cabeza Pereiro, Jaime: Ensayo sobre el trabajo precario y las personas vulnerables...op.cit., 45.

Por ejemplo, en el ordenamiento jurídico español las limitaciones a la no equiparación tienen, incluso, fundamento constitucional (art. 13 de la CE). En relación a la interpretación de los derechos fundamentales y las libertades públicas, véase la STC 107/1984, de 23 de noviembre, publicada en el BOE 21 de diciembre de 1984.

23 Taribini-Castellani Aznar, Margarita: Reforma y contrarreforma de la Ley de Extranjería (Análisis especial del trabajo de los extranjeros en España), Valencia, Tirant Lo Blanch, 2002, pág. 36. 
gozar de los derechos propios del Estado de Bienestar viene aparejada a la situación de regularidad del extranjero en España ${ }^{24}$.

Por su parte, la doctrina científica identifica como "inmigración" aquel fenómeno socioeconómico que consiste en el movimiento de entrada o llegada de personas a una región distinta a la de su país de origen. En la mayoría de las ocasiones, esa inmigración se produce desde territorios subdesarrollados hacia países desarrollados, siendo las razones principales que motivan este desplazamiento la búsqueda de una mejora en las condiciones de vida, salud y trabajo ${ }^{25}$. En este último caso, la inmigración plantea la cuestión de la integración social de los inmigrantes, la cual requiere conjugar básicamente la capacidad de absorción y/o necesidades de España -como país de acogida- con la presión inmigratoria (entendida ésta como el número de inmigrantes dispuestos a venir a la nación española $)^{26}$.

Siguiendo este razonamiento se afirma que, desde el punto de vista técnico-jurídico, no toda persona extranjera es inmigrante. Sin embargo, lo cierto es que la LOEXIs no distingue y cuando se refiere al inmigrante se remite al concepto de "extranjero" debido a que se confunden, en este concreto punto, los planos técnico-jurídico y material. En otras palabras, el concepto teleológico de "extranjero" que se describe en el artículo 1.1 de la LOEXIs se refiere, en realidad, al de "inmigrante"27. Para la ley 4/2000 esta diferenciación léxica no debe conducir a una diversificación semántica, de modo que cabe emplear indistintamente sendos conceptos términos para referirse a una misma realidad.

Una vez aclarado este aspecto cabe precisar ahora, ¿qué se entiende por "regularidad" e "irregularidad" del inmigrante en España? Resulta importante esta distinción, pues dependiendo de esto se hará o no extensible el derecho al disfrute de las prestaciones de Seguridad Social en igualdad de condiciones con los españoles ${ }^{28}$.

\footnotetext{
${ }^{24}$ Véanse las sentencias del Tribunal Constitucional 107/1984, de 23 de noviembre; 94/1993, de 22 de marzo; 116/1993, de 29 de marzo; 95/2000, de 10 de abril; 95/2003, de 22 de mayo y 72/2005, de 4 de abril.

${ }^{25}$ Junto al inmigrante también cabe considerar al refugiado y asilado que, por su condición social, tenga que ganarse la vida mediante su trabajo. En este caso, se equiparan ambas situaciones.

${ }^{26}$ Ruiz de Huidobro de Carlos, José María: "La ley Orgánica 4/2000: historia de un desencuentro y razón de su desenfoque jurídico"...op.cit., pág. 64.

27 "Si la finalidad del proceso legislativo es la integración social de los inmigrantes no es soslayable una de las cuestiones técnicas más arduas de una supuesta ley de inmigración cual es la definición jurídica de inmigrante o, de otro modo, la delimitación del ámbito de aplicación de las previsiones legales sobre su integración". Ruiz de Huidobro, José María: "Notas sobre el proceso de reforma legislativa en materia de extranjería e inmigración", Revista Migraciones, núm. 4, 1998, pág. 291.

${ }^{28}$ González Ortega, Santiago: "El derecho de los extranjeros extracomunitarios en situación irregular a prestaciones de Seguridad Social derivadas de contingencias comunes"... op.cit., pág. 241. Charro Baena, Pilar: "El derecho a la Seguridad Social de los solicitantes y beneficiarios de protección internacional", en VV.AA., Monereo Pérez, José Luis y Triguero Martínez, Luis Ángel (Dirs y Coords)., Refugiados y asilados ante el modelo social europeo y español. Estudio técnico-jurídico y de política del Derecho, Granada, Comares, 2016, págs. 258-259. 
En sentido negativo se presentan dos tipos de irregularidades. De un lado, la irregularidad total o absoluta y, de otro, la irregularidad relativa o laboral. Mientras que la primera aparece referida al extranjero que carece de la correspondiente autorización para trabajar y residir en España; la segunda únicamente describe la situación del inmigrante que no ha obtenido la autorización para trabajar. Para una parte de la doctrina científica esta última precisión carece de sentido, ya que normalmente la autorización para trabajar y residir se conceden en un único acto administrativo ${ }^{29}$.

Al margen de lo anterior, en la práctica se presenta otro tipo más de irregularidad, esto es, la llamada "irregularidad laboral sobrevenida". Se entiende que concurre esta circunstancia cuando caduca o no se renueva la pertinente autorización para trabajar en España. Sin embargo, caben incluir igualmente aquí aquellos supuestos en los que se concede la autorización para trabajar al extranjero que reside legalmente en España durante un año o, por tiempo inferior, siempre que acredite una situación de necesidad por circunstancias sobrevenidas de trabajar y con el fin de garantizar su subsistencia o el derecho a la reagrupación familiar (artículo 96.1 y 96.3 de RD 2393/2004, de 30 de diciembre, por el que se aprueba el Reglamento de la Ley Orgánica 4/2000, de 11 de enero, sobre derechos y libertades de los extranjeros en España y su integración social $\left.^{30}\right)$.

\section{Marco normativo regulador: universalidad versus desprotección social}

Tres son los artículos de la LOEXIs que se refieren a las prestaciones de Seguridad Social para inmigrantes, a saber: artículo 10 intitulado "Derecho al trabajo y a la Seguridad Social", artículo 14 sobre el "Derecho a la Seguridad Social y a los Servicios Sociales" y, finalmente, el artículo 36 en donde se concreta "La autorización de residencia y trabajo" necesarias para desempeñar una actividad lucrativa en España.

Comienza el artículo 10.1 de la Ley 4/2000 haciendo hincapié en los dos requisitos primordiales, de autorización de estancia y residencia, para poder gozar de los derechos de Seguridad Social a los que, posteriormente, se refiere esta ley. En concreto, se indica lo siguiente: "Los extranjeros residentes que reúnan los requisitos previstos en esta Ley Orgánica y en las disposiciones que la desarrollen tienen derecho a ejercer una actividad remunerada por cuenta propia o ajena, así como a acceder al sistema de la Seguridad Social, de conformidad con la legislación vigente". Destaca el hecho de que este apartado se refiera a la condición de "residente"31, lo que implica que el inmigrante habrá de de estar afiliado, en alta y cotizando (obligación que le corresponde al

\footnotetext{
${ }^{29}$ Valdueza Blanco, María Dolores: "Las situaciones administrativas de los extranjeros en España como condicionantes de los derechos socio-laborales", Relaciones Laborales, n², 2003, pág. 168-200.

${ }^{30}$ Artículo 96 redactado por el apartado veintisiete del artículo único del R.D. 1162/2009, de 10 de julio, por el que se modifica el Reglamento de la LO 4/2000, de 11 de enero, sobre derechos y libertades de los extranjeros en España y su integración social, aprobado por el R.D. 2393/2004, de 30 de diciembre (BOE de 23 julio).

${ }^{31}$ Inciso que fue introducido por el artículo 10 que redacta el apartado doce del artículo único de la LO 2/2009, de 11 de diciembre, de reforma de la LO 4/2000, de 11 de enero, sobre derechos y libertades de los extranjeros en España y su integración social (BOE de 12 diciembre).
} 
empresario) para poder disfrutar de las prestaciones contributivas ${ }^{32}$, pues de lo contrario, su acceso al sistema de protección social será limitado ${ }^{33}$. En otras palabras, el inmigrante en situación irregular no tendrá derecho a dichas prestaciones, aunque esté desempeñando un trabajo.

Claramente se pretende con esta previsión controlar la entrada de extranjeros en el mercado laboral español y al hilo de la situación de la mano de obra nacional ${ }^{34}$. Lo que, al término, conlleva que éstos acaben ocupando aquellos puestos de trabajo que no son desarrollados por la población autóctona ${ }^{35}$. Para lo cual se tiene en cuenta el catálogo de ocupación de difícil cobertura (CODC) que es elaborado por el Servicio Público de Empleo Estatal (SPEE). Asimismo, aun cuando un empleo no sea calificado como de difícil cobertura, el empresario podrá proceder a contratar a trabajadores inmigrantes siempre que acredite la insuficiencia de trabajadores cualificados nacionales y/o comunitarios para un determinado puesto de trabajo. Previamente éste deberá probar que ha gestionado la oferta pública de empleo a través del SPEE y que el resultado ha sido negativo ${ }^{36}$. De este modo el sistema público canaliza los flujos laborales al tiempo que controla la entrada de trabajadores en España.

No obstante, este artículo 10 de la LOEXIs no puede entenderse aisladamente, debiendo completarse con lo previsto por el artículo 14 de este mismo texto legal ${ }^{37}$ : "1. Los extranjeros residentes tienen derecho a acceder a las prestaciones y servicios de la Seguridad Social en las mismas condiciones que los españoles. 2. Los extranjeros residentes tienen derecho a los servicios y a las prestaciones sociales, tanto a las generales y básicas como a las específicas, en las mismas condiciones que los españoles. En cualquier caso, los extranjeros con discapacidad, menores de dieciocho años, que tengan su domicilio habitual en España, tendrán derecho a recibir el tratamiento, servicios y cuidados especiales que exija su estado físico o psíquico. 3. Los

\footnotetext{
${ }^{32}$ Monereo Pérez, José Luis y Vila Tierno, Francisco: "La (des)protección social del trabajador extranjero en situación irregular. La incidencia de las autorizaciones administrativas previas respecto al reconocimiento de la prestación por desempleo", Derecho de las Relaciones Laborales, nº11, 2017, págs. 1080 y 1081.

${ }^{33}$ González Ortega, Santiago: "El derecho de los extranjeros extracomunitarios en situación irregular a prestaciones de Seguridad Social derivadas de contingencias comunes"... op.cit., pág. 244.

${ }^{34}$ Aguilera Izquierdo, Raquel: "El acceso de los inmigrantes irregulares al mercado de trabajo: los procesos de regularización extraordinaria y el arraigo social y laboral", Revista del Ministerio de Trabajo y Asuntos Sociales, $\mathrm{n}^{\circ} 63,2006$, págs. 175-176.

${ }^{35}$ El acceso de los extranjeros al empleo, tal y como señala la Exposición de Motivos del RD 2393/2004, de 30 de diciembre, por el que se aprueba el Reglamento que desarrolla a la LOEXIs está basado en la "... necesidad de cobertura de puestos de trabajo y, salvo en los supuestos previstos por circunstancias excepcionales y por el paso desde una situación de residencia o de estancia por investigación o estudios a una autorización de residencia y trabajo, los inmigrantes que quieran desarrollar una actividad laboral deberán venir en origen con un visado que les habilite para trabajar o para buscar un empleo".

${ }^{36}$ Charro Baena, Pilar: "El trabajo de los extranjeros en España: Una lectura desde el ordenamiento laboral", Revista del Ministerio de Trabajo y Asuntos Sociales, nº3, 2006, págs. 68-71. Aguilera Izquierdo, Raquel: "El acceso de los inmigrantes irregulares al mercado de trabajo: los procesos de regularización extraordinaria y el arraigo social y laboral"...op.cit., pág. 176.

${ }^{37}$ Artículo 14 redactado por el apartado dieciséis del artículo único de la LO 2/2009, de 11 de diciembre, de reforma de la LO 4/2000, de 11 de enero, sobre derechos y libertades de los extranjeros en España y su integración social.
} 
extranjeros, cualquiera que sea su situación administrativa, tienen derecho a los servicios y prestaciones sociales básicas".

Nuevamente se insiste en que para que el inmigrante pueda gozar de las prestaciones y servicios de protección social, en igualdad de condiciones a los nacionales, deberá encontrarse en situación legal en España. Por lo que no basta con una mera estancia, sino que habrá de tramitarse la autorización de residencia conforme a los requisitos que enumera la LOEXIs y su reglamento de desarrollo, aprobado mediante RD Real Decreto 557/2011, de 20 de abril. En cuyo caso, el extranjero tendrá "... derecho a los servicios y a las prestaciones sociales, tanto a las generales y básicas como a las específicas, en las mismas condiciones que los españoles". A sensu contrario, cuando el inmigrante se encuentre en situación irregular en España sólo tendrá derecho a las prestaciones y servicios sociales básicos, pero no a las prestaciones contributivas del sistema ${ }^{38}$. Y es que no sólo basta con cumplir el requisito de la residencia, sino que también deberá desempeñar una actividad laboral. Lo cual no impide que éste pueda acceder al nivel no contributivo para que el que se exige, al margen de los rasgos de cada prestación, la situación real de carencias de recursos económicos ${ }^{39}$.

Finalmente, el marco normativo regulador de las prestaciones de Seguridad Social para los extranjeros en España se cierra con la previsión que recoge el artículo 36 de la LOEXIs sobre la "Autorización de residencia y trabajo". Resulta relevante destacar lo preceptuado por el apartado 5, en donde se refiere a la situación en particular de los inmigrantes irregulares, a saber: "La carencia de la autorización de residencia y trabajo, sin perjuicio de las responsabilidades del empresario a que dé lugar, incluidas las de Seguridad Social, no invalidará el contrato de trabajo respecto a los derechos del trabajador extranjero, ni será obstáculo para la obtención de las prestaciones derivadas de supuestos contemplados por los convenios internacionales de protección a los trabajadores u otras que pudieran corresponderle, siempre que sean compatibles con su situación. En todo caso, el trabajador que carezca de autorización de residencia y trabajo no podrá obtener prestaciones por desempleo. Salvo en los casos legalmente previstos, el reconocimiento de una prestación no modificará la situación administrativa del extranjero".

Son tres los puntos más conflictivos que se analizan en este artículo 36.5 de la LOEXIs: A) Los requisitos de autorización de trabajo y residencia serán determinantes para el acceso a las prestaciones de Seguridad Social. Ello deriva de los convenios internaciones que tratan de proteger al inmigrante para que no quede en una situación de desprotección social; B) No obstante si el extranjero carece de los anteriores requisitos, pero se encuentra trabajando, el contrato de trabajo no podrá ser declarado nulo. En otras palabras, la irregularidad laboral no impide que se generen los derechos a las

\footnotetext{
${ }^{38}$ Una parte de la doctrina científica opina que basta con la autorización de residencia para poder gozar del nivel contributivo. Roqueta Buj, Remedios: "Las condiciones de trabajo y Seguridad Social de los extranjeros en España", Revista de Derecho Migratorio y Extranjería, nº10, 2005, pág. 73.

${ }^{39}$ González Ortega, Santiago: "El derecho de los extranjeros extracomunitarios en situación irregular a prestaciones de Seguridad Social derivadas de contingencias comunes"... op.cit., pág. 245. 
correspondientes responsabilidades empresariales y de Seguridad Social; C) Finalmente, el trabajador irregular queda excluido de la posibilidad de disfrute del subsidio por desempleo en España.

Primeramente, el derecho al acceso o no a las prestaciones del sistema de Seguridad Social del inmigrante en situación irregular constituye un tema bastante conflictivo. Una buena parte de la doctrina científica opina que, aunque el extranjero no cumpla con los requisitos de autorización de residencia y trabajo, si está desempeñando una actividad profesional no puede negarse el derecho de acceso a las contingencias comunes, ya que se encuentra en situación asimilada al alta ${ }^{40}$. De la lectura al artículo 36.5 de la LOEXIs se deduce que dicha limitación no podrá impedir el disfrute de las contingencias de origen profesional que se reconozcan en los textos normativos y convenios de carácter internacional. Ahora las bien, las dudas se plantea respecto al amplio término de prestaciones "compatibles con su situación", al que alude el artículo 36.5 de la LOEXIs $^{41}$ y que fue incorporado con la reforma operada por la LO 14/2003, de 20 de noviembre, de reforma de la LOEXIs. Ciertamente, las fronteras entre las prestaciones originadas por contingencias comunes y profesionales no quedan claras aquí. Y es que, no se concretan en la LOEXIs cuáles son las prestaciones a las que tendrán acceso los inmigrantes. El artículo 42 del Real Decreto 84/1996, de 26 de enero, por el que se aprueba el Reglamento general sobre inscripción de empresas y afiliación, altas, bajas y variaciones de datos de trabajadores en la Seguridad Social establece: 1) Los extranjeros que cuenten con una autorización de estancia y trabajo en España quedan incluidos en el ámbito subjetivo de la Seguridad Social (artículo 42.1 del RD 84/1996); 2) Los extranjeros irregulares (o sea, sin autorización de residencia y trabajo) de países que hayan ratificado el Convenio número 19 de la Organización Internacional del Trabajo de 5 de junio de 1925- se incluyen en el sistema de Seguridad Social, pero sólo en determinadas circunstancias y a efectos de la protección frente a determinadas contingencias profesionales (artículo 42.2 del RD 84/1996); 3) Los extranjeros que, precisando de autorización administrativa previa para trabajar -los irregulares laborales-, desempeñen una actividad en España careciendo de dicha autorización, no estarán incluidos en el sistema de la Seguridad Social, sin perjuicio de que puedan considerarse incluidos a efectos de la obtención de determinadas prestaciones (artículo 42.2 del RD 84/1996). Esto último viene referido a las contingencias de origen profesional, ya que el propósito no es otro que reforzar la responsabilidad empresarial, lo que no implica legalizar indirectamente la situación administrativa de los irregulares en España ${ }^{42}$.

\footnotetext{
${ }^{40}$ Cabeza Pereiro, Jaime: "La protección de Seguridad Social de las personas extranjeras", Actualidad Laboral, n³, 2008. De igual modo, Gómez Abelleira, Francisco Javier: "La autorización de trabajo por cuenta ajena de los extranjeros no comunitarios: los efectos de su carencia", Revista del Ministerio de Trabajo y Asuntos Sociales, nº3, 2006.

${ }^{41}$ Montoya Melgar, Antonio: "El empleo ilegal de inmigrantes", Revista de derecho de la Unión Europea, nº17, 2009, págs. 21-26.

${ }^{42}$ Ruiz Cuesta, María y Muñoz Ruiz, Ana Belén: "Contrato de trabajo nulo y prestaciones de Seguridad Social", en VV.AA., Derechos y libertades de los extranjeros: XII Congreso Nacional de Derecho del Trabajo y de la Seguridad Social, Santander, Ministerio de Trabajo, 2001. 
El RD 84/1996 exigía para incluir en el ámbito subjetivo de aplicación de la Seguridad Social a los inmigrantes, antes de su modificación por el RD 1041/2005 ${ }^{43}$ de 5 de septiembre, una copia del permiso de trabajo ${ }^{44}$, lo que suponía un claro obstáculo. Sin embargo, con la redacción que al artículo 42 otorga el RD 1041/2005, de 5 de septiembre, la remisión al Convenio $\mathrm{n}^{\circ} 19$ de la OIT y a los riesgos profesionales es clara, a saber: "Los trabajadores por cuenta ajena extranjeros de países que hayan ratificado el Convenio número 199 de la Organización Internacional del Trabajo, de 5 de junio de 1925, que presten sus servicios sin encontrarse legalmente en España y sin autorización para trabajar o documento que acredite la excepción a la obligación de obtenerla, se considerarán incluidos en el sistema español de Seguridad Social y en alta en el régimen que corresponda a los solos efectos de la protección frente a las contingencias de accidentes de trabajo y enfermedades profesionales. Ello se entiende sin perjuicio de la aplicación, a los mismos efectos de protección, del principio de reciprocidad expresa o tácitamente reconocida (...)".

Evidentemente, este apartado 2 del artículo 42 del RD 84/1996 exige la autorización de trabajo como presupuesto de la ulterior afiliación y alta de extranjero, declarando expresamente que no basta con la mera solicitud para poder formalizar ésta. En consecuencia, la afiliación y alta sin previa autorización de trabajo ${ }^{45}$ constituyen "actos contrarios al ordenamiento jurídico" y, por tanto nulos ${ }^{46}$. De igual modo, el RD 2393/2004, indica para los trabajadores regulares ${ }^{47}$ por cuenta ajena, en su art. 51.12, que "a partir de la entrada legal en España del trabajador, podrá comenzar su actividad y se producirá su afiliación, alta y posterior cotización en los términos establecidos por la normativa de Seguridad Social que resulte de aplicación". Más aún, el art. 51.13 añade que, si al solicitar el extranjero autorizado su tarjeta de identidad o transcurrido un mes desde su entrada en España no consta su afiliación y alta a la Seguridad Social, la Administración procederá entonces a revocar la autorización (o lo que es lo mismo, se extinguirá la autorización). Para los trabajadores por cuenta propia, el Reglamento condiciona igualmente la afiliación, alta y cotización del inmigrante a su entrada legal en España, provisto del correspondiente visado (artículo 59.11).

De conformidad con dicho artículo 42 del RD 84/1996, así como el artículo 36.5 de la LOEXIs, el derecho al acceso a las prestaciones para los inmigrantes ha de resolverse

\footnotetext{
${ }^{43}$ Por el que se Modifican los reglamentos Generales sobre Inscripción de Empresas y Afiliación, Altas, Bajas y Variaciones de Datos de Trabajadores en la Seguridad Social; sobre Cotización y Liquidación de otros derechos de la Seguridad Social; de la recaudación de la Seguridad Social y sobre Colaboración de las Mutuas de Accidentes de Trabajo y Enfermedades profesionales de la Seguridad Social (BOE núm. 222 de 16 de septiembre de 2005).

44 "A las solicitudes de afiliación y alta de los trabajadores extranjeros, tanto por cuenta propia como por cuenta ajena, además de los datos y documentos requeridos para las de los trabajadores españoles, deberá acompañarse copia del correspondiente permiso de trabajo" (artículo 42 redactado por el RD 84/1996).

45 Práctica que se ha empleado en ocasiones para sanar una situación de ilegalidad. Fernández Collados, María Belén: "Los trabajadores extracomunitarios ante el sistema español de protección por desempleo", Aranzadi Social, nº10, 2003, págs. 1077-1080.

46 Véanse las sentencias del TSJ de Andalucía (Granada) de 13 de mayo de 1992 y de Murcia de 4 de octubre de 1999.

${ }^{47}$ Montoya Melgar, Antonio: "El empleo ilegal de inmigrantes"...op.cit., pág. 24. ISSN: 2174-6419

Lex Social, vol. 11, núm. 1 (2021)
} 
dependiendo de la situación administrativa de éstos en España. Y es que, no se olvide que, el art. 14.1 LOEXIs insiste en condicionar el acceso a las "prestaciones y servicios de la Seguridad Social" a la residencia de los extranjeros, así como los demás requisitos que obligan a los españoles. En concreto, el artículo 7.1 del Real Decreto Legislativo $8 / 2015$, de 30 de octubre, por el que se aprueba la Ley General de la Seguridad Social (LGSS) indica para los inmigrantes ilegales lo siguiente: a) sólo tendrán derecho a las prestaciones contributivas por contingencias comunes los extranjeros "que residan o se encuentren legalmente en España"; b) Se exige, al igual que a los españoles, que deberá éste ejercer (se sobreentiende que en condiciones legales) en territorio español una actividad comprendida en el campo de aplicación del Sistema (artículo 7.1 de la LGSS), de forma que se encuentre afiliado y en alta; C) Aparte, el inmigrante habrá de cumplir con el período de cotización exigido para cada contingencia (arts. 16 y siguientes de la LGSS). Obviamente, si el extranjero no reúne ninguno de estos requisitos no puede disfrutar de las prestaciones de Seguridad Social ${ }^{48}$.

Ahora bien ¿qué ocurre cuando el inmigrante ha trabajado, pero no se ha regularizado su situación administrativa en España debido a un incumplimiento empresarial? Lo primero que hay que tener en cuenta es que el contrato de trabajo no es nulo ${ }^{49}$, pero tampoco ello será obstáculo para la obtención de las prestaciones que pudieran corresponderle. En ese caso, perfectamente, el extranjero irregular laboral podrá generar el derecho a las prestaciones por contingencias comunes, además de las causadas por origen profesional ${ }^{50}$. Todo ello, sin perjuicio, de las responsabilidades penales o

\footnotetext{
${ }^{48}$ Véase la sentencia del TS de 14 de noviembre de 1997 y la del TSJ de Madrid de 6 de mayo de 2000.

${ }^{49}$ Ver las sentencias del Tribunal Superior de Justicia de Cantabria de 5 de abril de 2005 y del País Vasco de 13 de febrero de 2007. En esta línea, resulta interesante la doctrina del Tribunal Supremo (Sala de lo Social) en su sentencia de 17 de septiembre de 2013 (Rec. 2398/2012) en donde se ha establecido que, si bien el contrato de trabajo del extranjero, sin la preceptiva autorización, está afectado de la sanción de nulidad que establece la normativa (artículo 7.1 del ET y artículo de la 36.1 LOEX); la misma ley salva la sanción de nulidad proclamando su validez respecto a los derechos del trabajador afectado.

La Ley Orgánica 4/2000 de 11 de enero, establece que los empleadores que contraten a un trabajador extranjero deberán solicitar y obtener autorización previa del Ministerio de Trabajo y Asuntos Sociales. La carencia de la correspondiente autorización para contratos por parte del empleador, sin perjuicio de las responsabilidades a que dé lugar, no invalidará el contrato de trabajo respecto a los derechos del trabajador extranjero. Por otra parte, el apdo. 1, Art. 144 ,Ley General de la Seguridad Social, establece que la obligación de cotizar se inicia con la prestación de servicios por cuenta ajena, precepto determinante de que la Sala de lo Contencioso Administrativo de este Tribunal (Sentencia de 2 de diciembre de 1998, recurso de apelación número 9978/1992) haya declarado la obligatoriedad de cotizar por los extranjeros que presten servicios sin las correspondientes autorizaciones y permisos. Por lo tanto, el contrato de trabajo del extranjero no autorizado no es, en la actual legislación un contrato nulo. Y, siendo ello así no puede verse privado el trabajador de una protección que, en nuestro sistema de relaciones laborales, es inherente al contrato de trabajo y así lo ha sido siempre desde la primitiva Ley de Accidentes de Trabajo de 1900. Sentencias del TS, Sala de lo Social, $\mathrm{n}^{\circ}$ S/S, de 09/06/2003, Rec. 4217/2002, TS, Sala de lo Social, de 11/10/2006, Rec. 3562/2005 y TS, Sala de lo Social, $n^{\circ}$ S/S, de 29/09/2003, Rec. 3003/2002).

${ }^{50}$ Esto es, las prestaciones por accidentes de trabajo y enfermedades profesionales, "a los solos efectos" de las cuales se considera a los citados extranjeros en situación de alta de pleno derecho, como si fueran españoles, rigiendo en la materia el principio de automaticidad en el pago de las prestaciones, cuyo anticipo corre a cargo de la Entidad gestora o Mutua (STSJ de Cataluña de 20 de mayo de 2003), siendo responsables subsidiarios el Instituto Nacional de la Seguridad Social (INSS) y la Tesorería General de la Seguridad Social (TGSS).
} 
administrativas, incluso en materia de Seguridad Social, que dé lugar la carencia de la correspondiente autorización por parte del empresario ${ }^{51}$. En efecto, aunque la autorización administrativa para trabajar constituya requisito esencial para el contrato de trabajo, la falta del mismo no invalidará el mismo, lo cual no impide que el empresario pueda extinguir la relación laboral ${ }^{52}$. En estos casos, las consecuencias del despido suponen la calificación de improcedencia, pero no la readmisión debido a la situación irregular del trabajador inmigrante ${ }^{53}$. En otras palabras, para evitar conductas propiciadoras de "hechos consumados", el artículo 36.5 LOEXIs (tras la modificaciones operada por Ley 2/2009) persevera en que "el reconocimiento de una prestación no modificará la situación administrativa del extranjero", salvo que la ley disponga lo contrario (esto es, sólo "en los casos legalmente previstos") ${ }^{54}$.

\footnotetext{
${ }^{51}$ Sentencia del Tribunal Supremo, Sala de lo Social, de 21 de enero de 2010 (Rec. 106/2009).

En virtud de lo establecido en los artículo 54 y 55 de la LOEXIs, la contratación de trabajadores extranjeros sin haber obtenido con carácter previo la correspondiente autorización de trabajo constituye infracción calificada como muy grave, incurriendo el empresario en una infracción por cada uno de los trabajadores extranjeros ocupados en dicha situación irregular, pudiendo ascender cada multa desde 6001 euros hasta 60.000. Dicho importe se aumentará en la cuantía que resulte de calcular lo que hubiera correspondido ingresar por cuotas de Seguridad Social y demás conceptos de recaudación conjunta, desde el comienzo de la prestación de servicios del trabajador extranjero hasta el último día en que se constate dicha prestación, conforme a lo establecido en el Art. 48 ,Ley 62/2003, de 30 de diciembre.

Sin perjuicio de ello, los apartados 6 del artículo 55 de la LOEXIs y 5 del artículo 141 del Real Decreto 2393/2004, de 30 de diciembre, recogen como sanción accesoria la clausura del establecimiento o local desde seis meses a cinco años. Por su parte, los apartados 1 de artículo 57 de la Ley Orgánica 4/2000, de 11 de enero y el artículo 138 del Real Decreto 2393/2004, de 30 de diciembre, prevén como sanción alternativa a la multa la expulsión del territorio español del empresario extranjero infractor.

El expediente sancionador se iniciará por acta de la Inspección de Trabajo y Seguridad Social, de acuerdo con el procedimiento sancionador por infracciones del orden social, correspondiendo la imposición de las sanciones al Subdelegado del Gobierno o al Delegado del Gobierno en las Comunidades Autónomas uniprovinciales.

En este sentido, las sentencias del TSJ Murcia, Sala de lo Social, no 979/1999, de 04/10/1999, Rec. 1573/1998 y TS, Sala de lo Social, de 21/06/2011, Rec. 3428/2010.

${ }^{52}$ La Sentencia del TSJ de Cataluña de 1 de febrero de 2016 (Rec. 3717/2015) ha entendido que la autorización administrativa para trabajar, exigida a un extranjero no comunitario en España, constituye un requisito esencial del contrato de trabajo y, por lo tanto, forma parte de la base del negocio. Ahora bien, la pérdida de la misma, permite que la otra parte que actuó de buena fé,a partir del momento en que tuvo conocimiento de la misma, pueda resolver el contrato de trabajo. Y es que la falta de la misma, por consiguiente, supone la concurrencia de una "condición resolutoria" implícita en el contrato que debe permitir a la empresa, en aplicación del apartado 1 del artículo 49 del Estatuto de los Trabajadores (letra b) resolver el contrato de trabajo.

${ }^{53}$ La STS 29/09/2003 ( Sala de lo Social, Rec. 3003/2002 -), que versa sobre un supuesto similar al tratado, resolvió que el trabajador extranjero, sin permiso de trabajo ni residencia, tiene derecho a la aplicación de la normativa del Estatuto de los Trabajadores sobre extinción de la relación laboral, otorgando la protección que la citada normativa desarrolla a este efecto. Con la peculiaridad, en los casos de despido, de la desaparición de la posibilidad de readmisión por la situación de ilegalidad de los extranjeros que carecen de permiso de residencia.

Por lo que en caso de impugnar el despido, la condena judicial sólo se limitaría al pago de la indemnización sin conceder a la empresa la posibilidad de optar por la readmisión. Estableciéndose en otra sentencia (ver TSJ de Cataluña de 11 de enero de 1999), que los años trabajados sin permiso de trabajo no computarán para el cálculo de la indemnización que correspondiese por despido al trabajador extranjero.

${ }^{54}$ Montoya Melgar, Antonio: "El empleo ilegal de inmigrantes"...op.cit., págs. 22 y 23. ISSN: 2174-6419 Lex Social, vol. 11, núm. 1 (2021)
} 
En segundo lugar, aunque el inmigrante se encuentre en situación de irregularidad laboral (falta de autorización de trabajo) o plena en España (falta de autorización de residencia y trabajo), el empresario estará obligado a cotizar por ellos, pese a que legalmente no proceda su afiliación y alta ${ }^{55}$. Y todo ello conforme a la aplicación analógica de los artículo 9.256 del Real Decreto Legislativo 2/2015, de 23 de octubre, por el que se aprueba la Ley del Estatuto de los Trabajadores (ET) y el artículo 18 de la LGSS, en donde se establece que la obligación de cotizar le corresponderá al empresario "... desde el momento de iniciación de la actividad correspondiente" ${ }^{57}$. Se parte de la interpretación literal de que la obligación de cotización tiene por presupuesto el puro hecho de "la prestación del trabajo... sin referencia a contrato válido y sólo en función de la prestación de la actividad". En realidad, el empresario que no cumple con sus obligaciones de afiliación, alta y cotización de los trabajadores inmigrantes ilegales incurre en infracción administrativa no por haber omitido esos actos, sino por haber empleado ilegalmente al extranjero. Conforme a esta irregularidad, la Inspección de Trabajo podrá levantar acta de infracción para sancionar la contratación ilegal del inmigrante, pero no para sancionar su falta de afiliación, alta o cotización y, obviamente, tampoco podrá levantar acta de liquidación por tales descubiertos de cotización $^{58}$, ya que las mismas se entienden nulas por incumplimiento empresarial.

En tercer lugar, la compatibilidad para el disfrute de las distintas prestaciones dependerá de la situación administrativa en España (artículo 36.5 de la LOEXis). Si el inmigrante irregular (laboral o pleno) ha estado trabajando podrá disfrutar de las prestaciones de corto alcance (a excepción del desempleo) que haya generado como: la maternidad, la paternidad, la incapacidad temporal, riesgo durante el embarazo...etcétera. De igual modo, también podrá disfrutar de las prestaciones de largo alcance (como la jubilación y la incapacidad permanente), ya que resulta irrelevante aquí la autorización para trabajar y residir, máxime teniendo en cuenta que las prestaciones podrán exportarse ${ }^{59}$.

En cuarto lugar, hay que considerar al empresario como único responsable de las prestaciones de acuerdo con el artículo 167.2 de la LGSS, esto es: "El incumplimiento de las obligaciones en materia de afiliación, altas y bajas y de cotización determinará la exigencia de responsabilidad, en cuanto al pago de las prestaciones, previa la fijación de los supuestos de imputación y de su alcance y la regulación del procedimiento para hacerla efectiva". El incumplimiento de la obligación de solicitar autorización de trabajo resulta causa determinante para que el trabajador se convierta en irregular lo que, al tiempo, impide igualmente que éste cumpla con las obligaciones de afiliación, alta y

\footnotetext{
55 Resultan relevantes, en este punto, dos sentencias del Tribunal Supremo (Sala de lo Contencioso Administrativo) de de 28 de mayo de 1991 y 2 de diciembre de 1998.

56 "2. En caso de que el contrato resultase nulo, el trabajador podrá exigir, por el trabajo que ya hubiese prestado, la remuneración consiguiente a un contrato válido".

${ }^{57}$ Precepto que contiene idéntica cláusula que aquella que incluía el artículo 70.1 de la Ley de Seguridad Social de 1974, a saber: "La obligación de cotizar nacerá con el mismo comienzo de la prestación del trabajo, incluido el período de prueba".

${ }^{58}$ Montoya Melgar, Antonio: "El empleo ilegal de inmigrantes"...op.cit., págs. 22 y 23.

${ }^{59}$ González Ortega, Santiago: "El derecho de los extranjeros extracomunitarios en situación irregular a prestaciones de Seguridad Social derivadas de contingencias comunes"... op.cit., págs. 254-262. 
cotización. Es por ello que el citado precepto condicione la exigencia de responsabilidad a la "fijación de los supuestos de imputación". Desgraciadamente, en la actualidad este requerimiento no incluye a los inmigrantes ilegales, pues los preceptos aún aplicables son tan atormentados (a saber: los artículos 94 a 96 de la Ley de Seguridad Social de 1966) que circunscriben la responsabilidad empresarial a aquella que pueden exigir los trabajadores incluidos en el campo de aplicación del Régimen General y fuera del que se encuentran, evidentemente, los extranjeros sin autorización para trabajar en España. Por todo ello, el incumplimiento del deber de cotización genera repercusiones directas para el empresario en el ámbito de la Seguridad Social (que se ingresarán en la TGSS), lo que no impedirá asimismo la responsabilidad de éste en el terreno de las prestaciones cuyo derecho ha generado el trabajador irregular ${ }^{60}$. A este respecto, una parte de la doctrina sostiene que la responsabilidad del empresario no es aquí por aplicación del artículo 167.2 de la LGSS, sino por los daños que derivan del incumplimiento extracontractual de sus obligaciones ${ }^{61}$ (artículos 1101 y 1102 del Código Civil) o de una circunstancia ajena al contrato $^{62}$ (artículo 1902 del Código Civil).

Ningún fundamento existe para atribuir dicha responsabilidad prestacional a la Entidad Gestora, puesto que falta el presupuesto para que exista obligación de afiliación, alta y cotización de acuerdo con el artículo 167.1 de la $\operatorname{LGSS}^{63}$. Por lo tanto, no cabe el anticipo de las prestaciones, ni tampoco la automaticidad y la responsabilidad subsidiaria en caso de insolvencia del empresario ${ }^{64}$.

Finalmente, la exclusión del subsidio por desempleo de los trabajadores inmigrantes irregulares se erige en la única excepción para el acceso a las prestaciones de Seguridad Social de los inmigrantes ilegales. Sin perjuicio de que en el siguiente apartado se trate con más detenidamente este tema, conviene señalar ahora que, para el caso de la nación española, las normas de Seguridad Social supeditan el derecho a la protección por desempleo al principio de territorialidad, por lo que se condiciona su aplicación al hecho de que sus destinatarios deban cumplir con los requisitos de nacionalidad, residencia o trabajo en el territorio de un Estado miembro; por lo que si se dan estas condiciones, las

\footnotetext{
${ }^{60}$ Ceinos Suárez, Ángeles: El trabajo de los extranjeros en España, Madrid, La Ley, 2006.

${ }^{61}$ Ruiz Cuesta, María y Muñoz Ruiz, Ana Belén: "Contrato de trabajo nulo y prestaciones de Seguridad Social"...op.cit.

${ }^{62}$ Mercader Uguina, Jesús Rafael: "La protección social de los trabajadores extranjeros" en VV.AA., Derechos y libertades de los extranjeros: XII Congreso Nacional de Derecho del Trabajo y de la Seguridad Social, Santander, Ministerio de Trabajo, 2001. García- Perrote Escartín, Ignacio y Mercader Uguina, Jesús Rafael: "Extranjeros en situación irregular y responsabilidades empresariales en materia de Seguridad Social. Cambios jurisprudenciales", Justicia Laboral, nº16, 2003, págs. 5 a 9.

${ }^{63}$ Rodríguez Cardo, Iván Antonio: "Extranjeros en situación irregular: derechos laborales y de Seguridad Social tras las últimas decisiones del Tribunal Supremo y del Tribunal Constitucional", Actualidad Laboral, n5, 2009, pág. 1. Montoya Melgar, Antonio: "El empleo ilegal de inmigrantes"...op.cit., pág. 25. González Ortega, Santiago: "El derecho de los extranjeros extracomunitarios en situación irregular a prestaciones de Seguridad Social derivadas de contingencias comunes"... op.cit., pág. 260.

${ }^{64}$ Sentencia del TS de 4 de junio de 2000, RJ 2000/5116.
} 
personas inmigrantes tendrán, eventualmente, derecho a diferentes prestaciones siempre y cuando no sean de la misma naturaleza ${ }^{65}$.

\section{La protección por desempleo de los trabajadores inmigrantes}

La presencia de inmigrantes constituye, a día de hoy, una realidad estructural y compleja que se sitúa cada vez más en el centro neurálgico de la acción política y jurídica a desarrollar por parte de todos los Estados. El modo de afrontarla y gestionarla resulta de difícil aplicación en el marco de una sociedad globalizada, puesto que no existe actualmente una infraestructura institucional y jurídica adecuada a nivel internacional, que otorgue una respuesta uniforme al conjunto de interrogantes que se plantean dentro de los sistemas normativos de los diferentes países.

Los constantes movimientos de salida, entrada o ambos conjuntamente que sufren las naciones occidentales mayoritariamente han motivado el establecimiento de una serie de mecanismos de control con la intención de salvaguardar sus mercados de trabajo. En este sentido, algunos Estados se han visto verdaderamente desbordados en los últimos años, principalmente, a causa de una entrada masiva de personas en busca de posibilidades vitales que a duras penas encontraban en sus países de origen. Ya sea debido a razones geográficas, políticas, económicas o incluso sociales, una inmensa cantidad de personas han saturado las costas mediterráneas de la Unión Europea. Esta situación ha motivado que los Estados y otros actores tomen conciencia de la gravedad del problema, de ahí que se hayan adoptado desde el ámbito comunitario una serie de medidas de política jurídica de control de flujos enfocada a la racionalización económica $^{66}$ e incluso a la laboralización de las políticas migratorias ${ }^{67}$.

En concreto, la figura de la inmigración ha estado desde siempre presente en las medidas de política migratoria que se han adoptado a nivel europeo, aunque si bien de manera tangencial y limitada, pues muchas veces se ha asociado al fracaso del proyecto migratorio. En los últimos tiempos este fenómeno ha cobrado gran relevancia debido a la situación de crisis de empleo que viven los países receptores de esta mano de obra ${ }^{68}$, entre los que se encuentra España. Lo que ha implicado de lleno al sistema de políticas

\footnotetext{
${ }^{65}$ López Insua, Belén del Mar: "La protección frente al desempleo de las personas emigrantes de la Unión Europea"... op.cit., págs. 573 y siguientes.

${ }^{66}$ Monereo Pérez, José Luis y Triguero Martínez, Luis Ángel: "El modelo de política jurídica de inmigración y mercado de trabajo en España", Revista de derecho Migratorio y Extranjería, nº 29, 2012, pág. 12.

${ }^{67}$ Rojo Torrecilla, Eduardo y Camas Rodas, Ferrán: " Las reformas en materia de extranjería en el ámbito laboral: consolidación del modelo con reformulación de políticas, Temas Laborales, $\mathrm{n}^{\circ}$ 104, 2010, pág. 15.

${ }^{68}$ Charro Baena, Pilar: "Retorno voluntario de extranjeros extracomunitarios: Configuración general y medidas adoptadas en el contexto de crisis económica: La capitalización del desempleo", Revista del Ministerio de Empleo y Seguridad Social, ${ }^{\circ} 105,2013$, página 70. 
de empleo ${ }^{69}$, pues precisamente en momentos de recesión económica es más cuando surgen más necesidades y, precisamente, cuando menos recursos existen para hacer frente a dichas situaciones ${ }^{70}$.

Lamentablemente, la respuesta entre los distintos países se ha hecho notar de una forma poco deseable, siendo así muy dispares las medidas adoptadas entre ellos. Así pues, mientras que algunos Estados han optado por posibilitar la entrada de inmigrantes otros, por el contrario, han sacado a la luz las discrepancias en las decisiones políticas y la fragilidad de sus mercados. Principalmente, éste último ha sido el caso de España en donde la población inmigrante se han caracterizado por ocupar empleos poco cualificados y de carácter temporal ${ }^{71}$, lo que ha motivado el surgimiento de la irregularidad y la precariedad laboral. En toda crisis los estamentos más débiles son siempre los más perjudicados, especialmente ello incluye a la porción poblacional que representa a los extranjeros en situación irregular (laboral o plena). Esta crispada situación no sólo se ha traducido en un aumento del empleo sumergido, sino también en un crecimiento vertiginoso y de larga duración de los niveles de desempleo debido todo ello a la caída de la actividad productiva ${ }^{72}$. Se constata que la tasa de desempleo en España de extranjeros es más alta que la que representan los propios nacionales ${ }^{73}$.

En este contexto, las bases que sostienen al sistema de Seguridad Social se encuentran cada vez más debilitadas debido al daño que el incremento de la economía sumergida está causando en todos los sectores que se encuentran legalmente constituidos. Deplorable es, quizás, el término que mejor define la situación de todas aquellas personas que se ven abocadas a vivir en una espiral de pobreza y trabajo irregular a la espera de un empleo digno, moviéndose así en un terreno movedizo entre la legalidad y el fraude al sistema de Seguridad Social. Y es que, a día de hoy, el empleo sumergido y el fraude constituyen elementos centrales que inciden en la crisis de financiación del sistema de Seguridad Social y, en particular, de protección de las prestaciones por desempleo $^{74}$.

\footnotetext{
${ }^{69}$ De la Casa Quesada, Susana: "La inserción laboral de los inmigrantes", en VV.AA., Molina Navarrete, Cristóbal (Coord)., Empleo y mercado de trabajo: nuevas demandas, nuevas políticas, nuevos derechos, Sevilla, Consejo Andaluz de Relaciones Laborales (CARL), 2004, págs. 75-87.

${ }^{70}$ Fernández Avilés, José Antonio: "Los "renglones torcidos" de la política jurídica de protección por desempleo del trabajador extranjero inmigrante"...op.cit., pág. 3 en su versión digital.

${ }^{71}$ Charro Baena, Pilar: "Retorno voluntario de extranjeros extracomunitarios: Configuración general y medidas adoptadas en el contexto de crisis económica: La capitalización del desempleo"... op.cit., pág. 71.

${ }^{72}$ López Insua, Belén del Mar: "El fraude en las prestaciones por desempleo", Revista de Derecho de la Seguridad Social, $\mathrm{n}^{\circ} 3,2^{\circ}$ Trimestre de 2015, pág. 124.

${ }^{73}$ En particular, durante el año 2019 la tasa de desempleo en España de nacionales ha sido del 13,8\%,

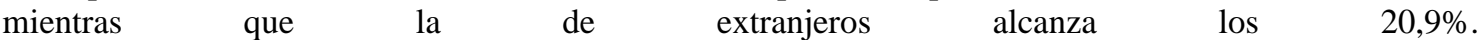
https://www.bde.es/f/webbde/SES/Secciones/Publicaciones/InformesBoletinesRevistas/NotasEconomica s/19/T2/descargar/Fich/be1902-ne04.pdf

${ }^{74}$ López Insua, Belén del Mar: "La lucha contra la precarización en el empleo desde la perspectiva de la Seguridad Social: desempleo o supervivencia en un contexto de crisis "económica" y "social", Revista IUSLabor, ${ }^{\circ} 1$, 2016, pág. 3-5. 
Actualmente, el artículo 263 de la LGSS estructura la protección por desempleo en dos niveles, de carácter público y obligatorio. De un lado, se encuentra el nivel contributivo (artículo 263.2 de la LGSS). Éste protege la situación de desempleo de quienes pudiendo y queriendo trabajar, pierden su empleo de forma temporal o definitiva o ven reducida temporalmente su jornada ordinaria de trabajo entre un mínimo de un $10 \%$ y un máximo de un $70 \%$. Para el acceso a la misma se requiere, además de cumplir los requisitos que enumera el artículo 266 de la $\mathrm{LGSS}^{75}$, la cotización previa del trabajador a la Seguridad Social por desempleo, dado que su financiación se efectúa por las cotizaciones de los trabajadores, de los empresarios y la aportación del Estado. De otro, aparece el nivel asistencial, que completa al anterior. La finalidad aquí es garantizar un nivel mínimo de protección a los trabajadores desempleados que cumplan con los requisitos que establecen los artículos 274 y siguientes de la LGSS (Título III, Capítulo III de la LGSS). Los inmigrantes irregulares, como más adelante se expondrá, no podrán acceder a este nivel asistencial puesto que se exige el agotamiento del nivel contributivo, aparte de tener ciertas responsabilidades familiares.

El desempleo o "paro forzoso" constituye, actualmente, uno de los mayores problemas económicos y sociales a los que debe enfrentarse una sociedad industrializada como la nuestra. No se trata de un fenómeno nuevo, sino que siempre ha existido ${ }^{76}$, haciendo notar su presencia con mayor esplendor en momentos de crisis económica ${ }^{77}$. Por lo que, al final, la situación de necesidad de aquellos que queriendo y pudiendo no encuentran empleo ha pasado de ocupar un papel "marginal" 78 a ser el principal escollo con el que ha tropezado la política de Seguridad Social y de empleo contemporánea.

\footnotetext{
${ }^{75}$ Los requisitos que recoge la LGSSS son los siguientes: A) Inscribirse como demandante de empleo y mantener dicha inscripción durante todo el período de percepción de la prestación. B) Estar afiliado y en situación de alta o asimilada al alta en la Seguridad Social, en un régimen que contemple la contingencia por desempleo. C) Estar en situación legal de desempleo. También se ha de acreditar la disponibilidad para buscar activamente empleo y para aceptar una colocación adecuada, mediante la suscripción de un compromiso de actividad. D) Tener cubierto un período mínimo de cotización por esta contingencia de 360 días, dentro de los seis años anteriores a la situación legal de desempleo o al momento en que cesó la obligación de cotizar. En el caso del emigrante retornado que cotizó al desempleo en España antes de emigrar, deberá tener cubierto un período mínimo de cotización de 360 días dentro de los 6 años anteriores a la fecha de emigración, siempre que no hayan sido computados para el nacimiento de un derecho anterior. Además, no deberá estar percibiendo la prestación por desempleo en ningún otro Estado del Espacio Económico Europeo o Suiza. E) No realizar una actividad por cuenta propia o trabajo por cuenta ajena a tiempo completo, salvo compatibilidad establecida por un programa de fomento de empleo. F) No haber cumplido la edad ordinaria que se exija en cada caso para causar derecho a la pensión contributiva de jubilación, salvo que el trabajador no tuviera derecho a ella por falta de acreditación del período de cotización requerido para ello o se trate de supuestos de suspensión de la relación laboral o reducción de jornada autorizados por resolución administrativa. G) No estar incluido en alguna de las causas de incompatibilidad.

${ }^{76}$ García Murcia, Joaquín: "Desempleo", VV.AA.: Desempleo. XIV Congreso Nacional de Derecho del Trabajo y de la Seguridad Social, Madrid, Ministerio de Trabajo y Asuntos Sociales, 2004, pág. 33.

77 Tobes Portillo, Paloma y Angoitia Grijalba, Miguel: "La protección por desempleo de los inmigrantes en España", Revista del Ministerio de Trabajo y Asuntos Sociales, n61, 2006, págs. 41-60.

${ }^{78}$ Monereo Pérez, José Luis.: El sistema de protección por desempleo en España, Valencia, Tirant lo Blanch, 1997, pág. 18. 
En todo Estado Social y Democrático se debe garantizar el derecho de toda persona a una existencia digna (artículo 10.1 Constitución Española- $C E)^{79}$, por lo que si no se consagra de forma efectiva el desarrollo de una actividad laboral (artículo 35.1 CE) deberán los Poderes Públicos intervenir. Estos habrán de hacer uso de los mecanismos de políticas de empleo (art. $40.1 \mathrm{CE})^{80}$, al tiempo que se activan los mecanismos sustitutivos del salario (lucro cesante) por el sistema de Seguridad Social ${ }^{81}$. Por lo que, al final, tendrá el Estado ${ }^{82}$ que buscar fórmulas de políticas activas de empleo (actuando en el campo de la formación, mejora en el acceso al empleo y fomento del mismo) ${ }^{83}$ y proteger al desempleado, en tanto se repara el daño patrimonial mediante la concesión de una prestación (políticas pasivas) ${ }^{84}$. De este modo, la protección por desempleo se inscribe dentro del marco de las políticas orientadas al pleno empleo por imperativo constitucional (artículos 35.1 y 40.1 CE) y aplicación de la normativa internacional ${ }^{85}$, al insertarse su tutela, de forma específica, en el artículo 41 de la Carta Magna ${ }^{86}$.

Una política eficaz de protección por desempleo precisa de un buen sistema que combine políticas de empleo con Seguridad social de forma que, en la línea trazada por las directrices de empleo de la Unión Europa, se logren medidas adecuadas que aumenten la "empleabilidad", pero que también busquen la inserción social de aquellos colectivos más vulnerables. Siendo así, quedarían superados los límites que impiden que el actual Estado del Bienestar actuar de una forma "pro-activa"87 y conforme a esa

\footnotetext{
79 Monereo Pérez, José Luis: La dignidad del trabajador. Dignidad de la persona en el sistema de Relaciones Laborales...op.cit.

80 "Si la política de pleno empleo es el instrumento de realización del Derecho del Trabajo y éste es un factor de integración y condición para la democracia se puede comprender por qué la política de empleo ha sido considerada como un elemento inherente a la forma política del Estado Social contemporáneo...". Ver, Monereo Pérez, José Luis.: Las nuevas políticas de protección por desempleo y su reflejo en el sistema jurídico, Valencia, Tirant Lo Blanch, 2003, págs. 9 a 31.

81 De acuerdo con nuestro modelo constitucional, el sistema público de la Seguridad Social es un elemento estructural y fundamental del Estado Social y Democrático de Derecho.

82 Aquí se incluyen también las distintas Administraciones Públicas (Nacional, autonómica y local), incluida las Supranacionales. García Murcia, Joaquín: "Desempleo"... op.cit., pág. 52 y siguientes.

83 A este respecto, cabe conectar la protección por desempleo con la organización de los servicios públicos de colocación. De esta forma, se facilita la consecución de un empleo gracias al desarrollo de "...acciones específicas de formación, perfeccionamiento, orientación, reconversión e inserción profesional en favor de los trabajadores desempleados, y aquellas otras que tengan por objeto el fomento del empleo estable. Todo ello sin perjuicio, en su caso, de las competencias de gestión de las políticas activas de empleo que se desarrollarán por la Administración General del Estado o por la Administración Autonómica correspondiente, de acuerdo con la normativa de aplicación".

${ }^{84}$ En definitiva, "la protección por desempleo (pasiva) y la política activa habrán de desenvolverse dentro de una misma programación: ni las acciones activas pueden desconocer la posibilidad del desempleado de obtener ingresos sustitutivos del salario, ni éstos pueden actuar en sentido contrario a los objetivos de incentivación del empleo...", ver García Murcia, Joaquín: "Desempleo"... op.cit., pág. 82.

${ }^{85}$ Monereo Pérez, José Luis.: Las nuevas políticas de protección por desempleo y su reflejo en el sistema jurídico... op.cit., pág. 34. Monereo Pérez, José Luis, Molina Navarrete, Cristóbal y Quesada Segura, Rosa: Manual de Seguridad Social... op.cit., pág. 445.

86 "Los poderes públicos mantendrán un régimen público de Seguridad Social para todos los ciudadanos que garantice la asistencia y prestaciones sociales suficientes ante situaciones de necesidad, especialmente en caso de desempleo".

${ }^{87}$ Monereo Pérez, José Luis: "Capítulo V. El sistema español de protección por desempleo: eficacia, equidad y nuevos enfoques", en VV.AA., Rodríguez Iniesta, Guillermo y Sánchez-Rodas Navarro, ISSN: 2174-6419 Lex Social, vol. 11, núm. 1 (2021)
} 
lógica jurídica que motiva el nacimiento del sistema de protección social, así como el derecho a una existencia digna en una sociedad democrática ${ }^{88}$.

No obstante, en el caso particular de los inmigrantes, la protección por desempleo encuentra aquí su principal traba debido a que éstos quedan directamente excluidos por vía del artículo 36.5 de la LOEXIs: ".... En todo caso, el trabajador que carezca de autorización de residencia y trabajo no podrá obtener prestaciones por desempleo". Una buena parte de la doctrina científica es bastante reacia a esta radical exclusión, al entender que si se ha prestado una actividad profesional el inmigrante en situación irregular, por consiguiente, ha de tener derecho al disfrute del subsidio por desempleo ${ }^{89}$. Cobra, en este punto, una especial relevancia la cobertura frente a las situaciones de necesidad e integración social ${ }^{90}$ que, a través de la medidas nacionales de desarrollo, reducen las situaciones de pobreza ${ }^{91}$ y de precariedad laboral. Como bien indica el artículo 2 ter de la LOEXIs: "Los poderes públicos promoverán la plena integración de los extranjeros en la sociedad española, en un marco de convivencia de identidades y culturas diversas sin más límite que el respeto a la Constitución y la ley". Por ello las medidas de protección por desempleo de los trabajadores inmigrantes habrá de orientarse siempre hacia los cauces de visibilización y normalización para así fomentar, en general, la integración de éstos en los sistemas generales de prestación de servicios y mecanismos de políticas activas de empleo ${ }^{92}$.

\subsection{El acceso a las prestaciones por desempleo de los trabajadores inmigrantes regulares}

De acuerdo con el artículo 13 de la Constitución Española y el artículo 3 de la LOEXIs, los inmigrantes regulares gozarán, en igualdad de condiciones que los españoles, de los mismos derechos y libertades fundamentales que se reconocen en el Título I de la Carta Magna, a excepción del derecho a participar en asuntos públicos y a funciones y cargos públicos, en donde habrá de seguirse lo dispuesto por los tratados y las leyes. En esta línea, el artículo 10 de la LOEXIs señala que los extranjeros que reúnan los requisitos previstos en esta ley tendrán derecho a ejercitar una actividad remunerada por cuenta

Cristina (Coord)., La protección por desempleo en España. XII Congreso Nacional de la Asociación Española de Salud y Seguridad Social (AESSS), Murcia, Laborum, 2015, págs. 131-135.

${ }^{88}$ Monereo Pérez, José Luis: "Las políticas activas de empleo. Derecho al trabajo y políticas activas de empleo en el marco de la política de empleo", en VV.AA., Monereo Pérez, José Luis; Fernández Bernat, Juan Antonio y López Insua, Belén del Mar (Dirs y Coords), Las políticas activas de empleo: Configuración y estudio de su regulación jurídica e Institucional, Navarra, Aranzadi, 2016, págs. 97-100.

${ }^{89}$ Montoya Melgar, Antonio: "El empleo ilegal de inmigrantes"... op.cit., págs. 21-26. Roqueta Buj, Remedios: "Las condiciones de trabajo y Seguridad Social de los extranjeros en España"... op.cit., pág. 75. Fernández Avilés, José Antonio: "Los "renglones torcidos" de la política jurídica de protección por desempleo del trabajador extranjero inmigrante"...op.cit., pág. 5 en su versión digital.

${ }^{90}$ Ver Sentencia del Tribunal de Justicia de la Unión Europea de 18 de diciembre de 2019, Asunto C$447 / 18$.

${ }^{91}$ VV.AA., Migración laboral internacional: un enfoque basado en los derechos, Ginebra, 2011. https://www.ilo.org/global/publications/ilo-bookstore/order-online/books/WCMS 125362/lang-en/index.htm

${ }^{92}$ Fernández Avilés, José Antonio: "Los "renglones torcidos" de la política jurídica de protección por desempleo del trabajador extranjero inmigrante"...op.cit., pág. 5 en su versión digital. 
ajena o propia, así como el acceso al sistema de Seguridad Social de conformidad con la legislación vigente.

Por su parte, el artículo 30 bis de la LOEXIs aclara que se encuentran en situación legal en España aquellos "residentes" extranjeros que sean titulares de una autorización para residir. Por contra, aquellos que no cumplan con este requisito se hallarán en situación irregular en España, lo cual implica que sólo podrán acceder a los servicios y prestaciones sociales básicas (artículo 14.3 de la LOEXIs). En otras palabras, a efectos de las prestaciones del Sistema de Seguridad Social, no existe ninguna duda respecto a la igualdad de condiciones entre extranjeros regulares y españoles, ya que así se recoge en el artículo 14.1 de la Ley Orgánica 4/2000. Ahora bien, en lo que refiere a la protección por desempleo, el artículo 14.2 garantiza explícitamente lo siguiente: "Los extranjeros residentes tendrán derecho a los servicios y a las prestaciones sociales, tanto a los generales básicos como a los específicos, en las mismas condiciones que los españoles".

El criterio de residencia legal no queda frustrado ${ }^{93}$, ni tampoco limitado por el hecho de que el extranjero viaje fuera de España por un periodo de 90 días. Así lo declara el Tribunal Supremo en su sentencia de 18 de octubre de 2012 (con número de recurso 4325/2011). Los hechos sobre los que versa este asunto traen su causa en la sentencia del Tribunal Superior de Justicia de Madrid de 15 de noviembre de 2001. El TSJ falla a favor del Servicio Público de Empleo Estatal y, en contra, de una mujer de nacionalidad ucraniana que, sin previo aviso, había viajado a su país natal para atender a su suegro enfermo de una angina de pecho. El SPEE le reclama a la extranjera la devolución de la prestación por desempleo, en particular de los 15.368 euros cobrados.

En esta interesante sentencia el Tribunal Supremo delimita el concepto de "traslado de residencia" a los efectos del artículo 213 g) de la LGSS de 1994 (actual artículo 217 de

\footnotetext{
${ }^{93}$ Sentencia del Tribunal de Justicia de la Unión Europea (Sala Tercera) de 11 de abril de 2019, asunto C-483/17. En este caso, expresa el Tribunal de Justicia ha declarado que la posibilidad de que un ciudadano de la Unión que haya dejado temporalmente de ejercer una actividad por cuenta ajena o por cuenta propia mantenga su condición de trabajador sobre la base del artículo 7, apartado 3, de la Directiva 2004/38 y el derecho de residencia que le corresponde, en virtud del artículo 7, apartado 1, de dicha Directiva, se basa en la premisa de que ese ciudadano esté disponible o sea apto para reincorporarse al mercado de trabajo del Estado miembro de acogida en un plazo razonable (sentencia de 13 de septiembre de 2018, Prefeta, C-618/16, EU:C:2018:719, apartado 37). En efecto, el artículo 7, apartados 1, letra a), y 3, letra c), de la Directiva 2004/38/CE del Parlamento Europeo y del Consejo, de 29 de abril de 2004, relativa al derecho de los ciudadanos de la Unión y de los miembros de sus familias a circular y residir libremente en el territorio de los Estados miembros, debe interpretarse en el sentido de que un nacional de un Estado miembro que ha ejercido su derecho de libre circulación y ha adquirido en otro Estado miembro la condición de trabajador en el sentido del artículo 7, apartado 1, letra a), de esta Directiva gracias a la actividad que ha ejercido en el mismo durante un período de dos semanas —en virtud de un contrato que no es de duración determinada - antes de quedar en paro involuntario mantiene la condición de trabajador durante un período adicional de al menos seis meses en el sentido de estas disposiciones, siempre que se haya inscrito en el servicio de empleo competente con el fin de encontrar un trabajo. Ahora bien, corresponderá al órgano jurisdiccional remitente determinar si, de conformidad con el principio de igualdad de trato reconocido en el artículo 24, apartado 1, de la Directiva 2004/38, dicho nacional tiene, en consecuencia, derecho a percibir prestaciones de asistencia social o, en su caso, de seguridad social en las mismas condiciones que si fuera nacional del Estado miembro de acogida. 
la LGSS) y, de igual modo, aborda el alcance de las obligaciones de comunicación y documentación a cargo de los beneficiarios, a saber: el período de libranza del artículo 6.3 RD 625/1985 (redacción RD 200/2006), así como el cuadro de situaciones de prestación "mantenida", prestación "extinguida" y prestación "suspendida". El Alto Tribunal establece que la aplicación de la doctrina general conduce a la conclusión de que el caso de esta mujer corresponde a un supuesto de prestación "suspendida" y no de prestación "extinguida", como pretende la entidad gestora y ha resuelto la sentencia recurrida. El Tribunal Supremo falla en el sentido de que la prestación "suspendida" durante la ausencia de España se reanuda en el momento de reintegrarse el beneficiario al territorio español. Aparte, el TS fija el plazo de ausencia en 90 días porque, de acuerdo con la LOEXIs, es el que corresponde al periodo de paso entre la estancia y la residencia temporal.

En este mismo sentido, se pronuncia el Tribunal Supremo en su sentencia de 5 de julio de 2017 (número de recurso 1554/2015) al entender que la puesta en marcha de este mecanismo sancionador, por parte de la Entidad Gestora (en este caso, el SPEE), supone una discriminación clara entre ciudadanos en función de factores, tales como: la nacionalidad, el sexo, la raza...etcétera.

Para los inmigrantes no comunitarios que generen el derecho al subsidio y que estén pendiente de percibirlo se establece, a través del Real Decreto-Ley 4/2008 de 19 de septiembre ${ }^{94}$, una modalidad específica de pago único de la prestación contributiva por desempleo que podrá disfrutar siempre que éstos decidan retornar a sus países de origen 95. Se trata ésta de una forma de fomento del retorno/expulsión del inmigrante que busca, de una parte, disminuir los índices de desempleo en España al tiempo que, de otra, pretende la reinserción laboral del extranjero en su país natal (ya sea para trabajar por cuenta propia o ajena) ${ }^{96}$. Supone una medida, claramente, expulsiva que contradice las bases mismas para la integración social de inmigrantes a la que aspira la LOEXIs y el conjunto de políticas de codesarrollo (comunitarias e internacionales). La idea es establecer medidas de desarrollo de la actividad económica en los países de origen para evitar que vuelvan a España. Es por ello que la doctrina científica califique a esta medida como de "retro-inmigración" o "compra de retorno"97, al contemplar la

\footnotetext{
94 Sobre abono acumulado y de forma anticipada de la prestación contributiva por desempleo a extranjeros no comunitarios que retornen voluntariamente a sus países de origen (BOE núm. 228 de 20 de septiembre de 2008).

95 Y que desarrolla el Real Decreto 1800/2008, de 3 de noviembre (BOE 272, de 11 de noviembre de 2008.

96 En concreto, se indica en este Real Decreto-Ley 4/2008 lo que sigue: ".... cuando el trabajador desempleado pretende constituirse como trabajador autónomo o en los casos en que vaya a incorporarse, de forma estable, como socio trabajador o de trabajo en cooperativas o en sociedades laborales".

97 De la Villa de la Serna, Diego: "Medidas de fomento de la retro-inmigración. Comentario al real decreto-Ley 4/2008, de 19 de septiembre y sus normas complementarias", Revista General de Derecho del Trabajo y de la Seguridad Social, nº18, 2008, págs. 3 y siguientes. Cabeza Pereiro, Jaime: "El pago único de la prestación de desempleo a los inmigrantes que retornen: Primeras notas", Actualidad Laboral, n 21, 2008. Cavas Martínez, Faustino: "El Derecho Social ante la crisis", Revista Aranzadi Social, n¹9, 2009, pág. 23. Maldonado Molina, Juan Antonio: "Pago anticipado del desempleo a los inmigrantes: ISSN: 2174-6419 Lex Social, vol. 11, núm. 1 (2021)
} 
posibilidad de que estas personas no puedan regresar en un plazo de tres años (artículo único, apartado cuatro).

La capitalización de la prestación por desempleo que se pretende con el Real DecretoLey 4/2008 se aleja del objetivo de protección de estos trabajadores en situación de necesidad y se centra en los objetivos de retorno, para lo que se podrán establecer ayudas directas. En efecto, indica la Disposición final única que: "... el Gobierno, dentro de los créditos disponibles, podrá establecer ayudas directas que faciliten el traslado voluntario de los trabajadores extranjeros no comunitarios a sus países de origen, así como acciones preparatorias del retorno, en materia de información, orientación y formación para el emprendimiento de una actividad económica".

Para poder ser beneficiario de esta medida el extranjero regular deberá formar parte de un programa de fomento del empleo y tener suscrito, entre España y su Estado de origen, un convenio bilateral en materia de Seguridad Social. Llama la atención que, a lo largo del cuerpo de este Real Decreto-Ley, no se vuelva a hacer referencia o alusión a la necesidad de estar incluido en un programa de fomento del empleo ${ }^{98}$. Sin embargo, sí que se concretan en la norma otros requisitos que, con carácter obligatorio, deberá cumplir el inmigrante. Se tratan de los siguientes: a) Estar inscritos como demandantes de empleo en el Servicio Público de Empleo correspondiente. b) Hallarse en situación legal de desempleo como consecuencia de la extinción de la relación laboral por alguna de las causas previstas en el apartado. 1, art. 266 de la LGSS. c) Tener reconocido el derecho a la prestación por desempleo de nivel contributivo, sin compatibilizarlo con un trabajo a tiempo parcial. d) Asumir el compromiso de retornar a su país de origen y el de no retornar a España en el plazo de tres años para residir y/o realizar una actividad lucrativa o profesional por cuenta propia o ajena. e) No estar incurso en los supuestos de prohibición de salida del territorio nacional previstos en la legislación de extranjería. A estos efectos el Servicio Público de Empleo Estatal deberá recabar la oportuna información de la Dirección General de la Policía y de la Guardia Civil que deberá proporcionarse de forma inmediata.

Los compromisos que ha de formalizar el trabajador inmigrante con el SPEE están basados en una lógica claramente contractualista ${ }^{99}$, en donde se imponen por ley fuertes límites para evitar que el extranjero regrese a España. Y no sólo eso sino que, además,

¿Fomento de empleo o del retorno?, en VV.AA., Fernández Avilés, José Antonio y Moreno Vida, $M^{a}$.Nieves (Dirs); Ortega Pérez, Nieves, Guillén López, Enrique, Durán Ruíz, Francisco Javier y Triguero Martínez, Luis Ángel (Coord)., Inmigración y crisis económica: retos políticos y de ordenación jurídica, Granada, Comares, 2011, págs. 627- 643. Fernández Avilés, José Antonio: "Los "renglones torcidos" de la política jurídica de protección por desempleo del trabajador extranjero inmigrante"...op.cit., pág. 6 en su versión digital.

98 Maldonado Molina, Juan Antonio: "Pago anticipado del desempleo a los inmigrantes: ¿Fomento de empleo o del retorno?... op.cit., pág. 632.

99 Álvarez Cortés, Juan Carlos y Plaza Angulo, Juan José: "El desempleo en su modalidad de pago único como ayuda a nuevos emprendedores", Temas Laborales, no 95, 2008. Fernández Avilés, José Antonio: "Los "renglones torcidos" de la política jurídica de protección por desempleo del trabajador extranjero inmigrante"...op.cit., pág. 7 en su versión digital. 
si el inmigrante decide retornar voluntariamente ${ }^{100}$, implícitamente, se entenderá que está renunciando a la posibilidad de recibir la ayuda económica del subsidio por desempleo (art. 4.3.b) RD 1800/2008) y la renta mínima de inserción. Por lo que no se trata sólo de una renuncia al derecho, sino que la norma va más allá al sancionar al inmigrante con su desprotección desde el punto de vista de la Seguridad Social y del principio de libre circulación. De igual modo resulta bastante desacertada la posibilidad de acceder a otros mecanismos protectores de corte más asistencialista, como son los programas de rentas mínimas puestos en marcha en las distintas Comunidades Autónomas ${ }^{101} \mathrm{o}$, incluso, las autorizaciones de residencia transcurridos 30 días naturales desde la fecha en la que se realice el primer pago (art. 6.1 RD 1800/2008) ${ }^{102}$. De acuerdo con el artículo único, apartado 4, del RD-Ley 4/2008 se entenderá que: a) el plazo de 30 días naturales para retornar al país de origen se contará a partir de la fecha de realización del primer pago en España de la prestación, pero para ello el extranjero deberá tener reconocido el derecho ( $40 \%$ del importe del subsidio) y b) el plazo de tres años de compromiso de no retorno a España empezará a contarse transcurridos 30 días naturales, a partir de la fecha del primer pago citado anteriormente.

Las condiciones y consecuencias del abono, anticipado y acumulada, en dos veces, del importe de la prestación contributiva por desempleo se regirá por lo establecido en el artículo único del Real Decreto-ley 4/2008, de 19 de septiembre y por el apartado 1 del art. 3 Real Decreto 1800/2008, de 3 de noviembre. Ahora bien, en lo no previsto expresamente por sendas leyes, se estará a lo dispuesto en el texto refundido de la LGSS. En particular, el abono acumulado y de forma anticipada del importe de la prestación contributiva por desempleo se realizará en dos plazos, con las siguientes cuantías (art. 4 RD 1800/2008, de 3 de noviembre): a) Un 40\% se abonará en España, una vez reconocido el derecho y b) El $60 \%$ restante se abonará en el país de origen, una

100 Valdés Dal-Ré, Fernando: "Las expulsiones colectivas de extranjeros: su tratamiento en el ordenamiento internacional y la jurisprudencia del TEDH", Derecho de las Relaciones Laborales, $\mathrm{n}^{\circ} 4 \mathrm{de}$ abril, 2018, págs. 358-359.

${ }^{101}$ Fernández Avilés, José Antonio: "Los "renglones torcidos" de la política jurídica de protección por desempleo del trabajador extranjero inmigrante"...op.cit., pág. 7 en su versión digital.

102 "Transcurrido el período de tres años indicado, los trabajadores que hubieran tenido residencia temporal, acogidos a la modalidad de abono acumulado y anticipado de la prestación contributiva por desempleo, podrán solicitar de nuevo las autorizaciones administrativas para trabajar y residir en España, de acuerdo con lo previsto en la normativa vigente en materia de extranjería e inmigración. De igual modo, los interesados ostentarán un derecho preferente para incorporarse al contingente de trabajadores extranjeros no comunitarios que apruebe el Gobierno, siempre que acrediten los requisitos establecidos para ello en la normativa vigente en materia de extranjería e inmigración, en el correspondiente Acuerdo del Consejo de Ministros y en las respectivas ofertas de empleo.

Los titulares de autorización de residencia temporal que sean beneficiarios del abono acumulado y anticipado de la prestación económica contributiva por desempleo, que regresen a España tras el cumplimiento de su compromiso de no retorno de acuerdo con lo previsto en el párrafo anterior, verán continuada su situación de residencia a los efectos del cálculo del plazo legal para obtener, en su caso, la residencia permanente, si bien no se computará en ese cálculo el período de ausencia.

Asimismo, los residentes permanentes beneficiarios de dicho abono acumulado y anticipado de la prestación contributiva por desempleo que regresen a España tras la finalización de su compromiso de no retorno recuperarán su condición de residentes permanentes mediante un procedimiento simplificado que se establecerá reglamentariamente". 
vez que haya transcurrido el plazo de 30 días naturales contados a partir de la realización del primer pago y en el plazo máximo de noventa días desde dicho primer pago. Para recibir este abono, el trabajador deberá comparecer personalmente en la representación diplomática o consular española en el país de origen para acreditar su retorno al mismo. En dicho momento deberá proceder a la entrega de la tarjeta de identidad de extranjero de la que es titular.

El SPEE procederá a realizar este pago a partir de que le sea comunicada ${ }^{103}$ dicha comparecencia en la representación diplomática o consular por la Dirección General de Asuntos y Asistencia Consulares del Ministerio de Asuntos Exteriores y de Cooperación. Resulta sorprendente que no se prevea aquí ningún mecanismo de control que garantice la inversión del capital al inicio de la actividad económica, pues el objetivo no es otro que el de asegurar el retorno.

Una vez producido el abono, la prestación contributiva por desempleo en la modalidad de pago acumulado y anticipado: 1) se considerará extinguida por agotamiento del plazo de duración de la prestación. 2) Tal y como se ha indicado más arriba, no se podrán acceder al resto de niveles de protección por desempleo (al haber agotado la prestación), incluido el subsidio establecido para los trabajadores mayores de 52 años (apartado 4 del artículo 274 LGSS). Y 3) no se podrá acceder a las prestaciones y subsidios por desempleo en un período de, al menos, tres años contado a partir de la fecha del compromiso de no retorno a España.

Finalmente, las obligaciones de los beneficiarios se concretan en dos importantes puntos. Primero, los solicitantes del abono anticipado y acumulado de la prestación contributiva por desempleo proporcionarán la documentación e información que se requiera para el reconocimiento y pago de la prestación, y de los beneficiarios cumplir los compromisos adquiridos y las condiciones establecidas para ser beneficiario de dicha modalidad de pago de la prestación contributiva por desempleo, así como reintegrar, en su caso, el importe de las prestaciones indebidamente percibidas. Segundo, los solicitantes procederán al reintegro de los importes indebidamente percibidos en los siguientes casos: a) Cuando se hubiera obtenido la prestación falseando los requisitos requeridos para su obtención; b) Cuando se hubiera revocado el derecho a la prestación por desempleo de nivel contributivo y c) Cuando se hubieran incumplido los compromisos adquiridos y las condiciones señaladas en el artículo único del RD-ley 4/2008, de 19 de septiembre y el RD 1800/2008, de 3 de noviembre.

Todas estas previsiones se entenderán, sin perjuicio de la aplicación, cuando proceda, del Real Decreto Legislativo 5/2000, de 4 de agosto, por el que se aprueba la Ley de Infracciones y Sanciones en el Orden Social (LISOS) y de la LOEXIs.

${ }^{103}$ Le corresponde al Servicio Público de Empleo Estatal la recepción de solicitudes, tramitación, reconocimiento y pago de la prestación reconocida, así como la declaración de la extinción del derecho a dicha prestación por agotamiento del plazo de duración de la prestación. Ver la sentencia del TSJ de Castilla y León de 15 de noviembre de 1999. 
La aplicación de esta medida "excepcional" aparece en un momento coyuntural de crisis económica. Sin embargo, a pesar del paso del tiempo, lo cierto es que se ha mantenido bajo un propósito "pretendidamente de protección y fomento del empleo", cuando lo cierto es que se busca el retorno del extranjero a toda costa. Pese a los objetivos, las estadísticas reflejan que son bastante escasas las solicitudes y ello es porque los extranjeros prefieren permanecer en España, sea cual sea su precio, en lugar de correr el riesgo en una sociedad sujeta a riesgos de desarraigo y exclusión. Empero no parece que ello sea un obstáculo, ya que lo que importa es que la medida sea efectiva en el sentido de que los que se marchen no retornen más a España ${ }^{104}$.

Así lo confirma la actual Ley de Empleo de 2015 (Real Decreto Legislativo 3/2015, de 23 de octubre, por el que se aprueba el texto refundido de la Ley de Empleo) al indicar que, entre sus objetivos (artículo 2 letra g) -en consonancia con los que indica el artículo 18.h).4-) se encuentran los siguientes: "coordinar la articulación del empleo con la dimensión del fenómeno migratorio interno y externo", para lo que lo cual el SPEE deberá centrar sus esfuerzo en poner en funcionamiento "Programas de intermediación y políticas activas de empleo cuyo objetivo sea la integración laboral de trabajadores migrantes realizados en sus países de origen, facilitando la ordenación de los flujos migratorios".

Sin lugar a dudas, no puede afirmarse que se cumpla con el marco general de protección por desempleo en España y de fomento de las políticas de inserción social de inmigrantes ${ }^{105}$. Y es que, en el peor de los casos, cuando el inmigrante no retornado agote todos los niveles de protección por desempleo acabará refugiándose en nichos de actividad subalterna, lo que contribuye al mantenimiento de la precariedad laboral y la economía sumergida. Algo ya muy frecuente y característico en este colectivo. La problemática que suscita esta situación nos hace plantear, desde el punto de vista de la finalidad misma del derecho social, múltiples dudas. Y es que, lamentablemente brilla aquí por su ausencia la misma noción de trabajo decente que tanto se reivindica en el ámbito internacional y comunitario, de ahí que no se pueda adoptar una actitud pasiva e indiferente a esta realidad que se vive.

Todo ello se traduce en un empobrecimiento del Estado de Bienestar social debido a que las inmigrantes, primordialmente en situación irregular, vienen satisfaciendo unas necesidades sociales no atendidas por el Estado, ni tampoco por los nacionales. En efecto, el factor étnico está obstaculizando cada vez la integración laboral de estas personas, al tiempo que las convierte en ciudadanos de segunda clase (e incluso, tercera clase) y, por tanto, carentes de derechos fundamentales.

\footnotetext{
${ }^{104}$ Maldonado Molina, Juan Antonio: "Pago anticipado del desempleo a los inmigrantes: ¿Fomento de empleo o del retorno?... op.cit., pág. 643.

105 Monereo Pérez, José Luis: La dignidad del trabajador. Dignidad de la persona en el sistema de Relaciones Laborales... op.cit., págs. 111-128. 


\subsection{Un constante tira $y$ afloja: La exclusión de los trabajadores inmigrantes irregulares de la protección por desempleo}

El grado de protección social de los inmigrantes en España constituye un tema muy conflictivo, ya que de una lado se defiende la necesidad de fomentar la plena inclusión social de estos ciudadanos de terceros países en igualdad de condiciones a los nacionales (interpretación amplia del artículo 13 de la CE) ${ }^{106}$, pero de otra subsiste esa idea de control policial de los constantes flujos de entrada de extranjeros y de reparto equitativo poblacional en el entorno de la UE.

Se trata éste de un tema baladí que trae su base en las imprecisiones del artículo 13 de la $\mathrm{CE}$, por el que se supedita la consecución de un estatuto jurídico de igualdad (entre extranjeros y nacionales) en base a lo dispuesto por los "tratados y la ley". Podría decirse que no es ésta una cuestión que afronte directamente y claramente el artículo 13 de la CE, sino que lo deja en manos del legislador nacional, comunitario e internacional ${ }^{107}$. De ahí esa disparidad en torno al concepto de ciudadanía inclusiva ${ }^{108}$.

Ciertamente, el artículo 13 de la Carta Magna adolece de un cierto grado de imprecisión que propicia diferentes interpretaciones doctrinales y jurisprudenciales. Para una buena parte de la doctrina científica, esa falta de concreción implica una clara desconstitucionalización de los derechos fundamentales de los extranjeros, por la dependencia de la correspondiente titularidad a lo dispuesto en la Ley o tratados que se acuerden ${ }^{109}$. En sentido contrario, el Tribunal Constitucional ofrece una interpretación amplia de este artículo 13 de la CE que supone que los extranjeros podrán ser titulares de todo el elenco de derechos reconocidos en el Título I de la CE. Dependiendo del

\footnotetext{
${ }^{106}$ Martínez-Abascal, Vicente Antonio: "Seguridad Social e inmigración: la ardua forja de una ciudadanía social plena", en VV.AA., Monereo Pérez, José Antonio, Molina Navarrete, Cristóbal y Moreno Vida, M ${ }^{\mathrm{a}}$ Nieves (Coords)., La Seguridad Social a la luz de sus reformas pasadas, presentes y futuras. Homenaje al Profesor José Vida Soria con motivo de su jubilación, Granada, Comares, 2008.

107 "La aprobación de la Constitución, en diciembre de 1978, significó un cambio decisivo para los ciudadanos, pero también tuvo influencia directa en la regulación de la inmigración, aunque no se observó de manera tan clara e inmediata. De hecho, en 1978 aún pesaba mucho más la preocupación por la emigración de los españoles en Europa que por la casi inapreciable inmigración que llegaba a España, a menudo de paso para el resto de Europa. Es muy significativo que la Constitución dedique un precepto específico, el artículo 42, a los emigrantes encomendando al Estado velar por los derechos de los trabajadores españoles en el extranjero y promover su retorno, y en cambio no dijera nada de la inmigración, limitándose a fijar las reglas generales de la extranjería". Ver Aja, Eliseo: "Capítulo 1. La evolución normativa sobre la inmigración", en VV.AA., Aja, Eliseo y Arango, Joaquín (Coords), Veinte años de inmigración en España. Perspectiva jurídica y sociológica (1985-2005)., Madrid, Anuario de Inmigración en España, 2005, págs. 6 y siguientes.

108 Monereo Pérez, José Luis y Molina Navarrete, Cristóbal: "Ciudadanía, solidaridad y extranjería: el derecho a la inserción de los inmigrantes", en VV.AA., Monereo Pérez, José Luis, Molina Navarrete, Cristóbal y Moreno Vida, Ma . Nieves (Dirs.), Comentario a la Constitución Socioeconómica de España, Granada, Comares, 2002, págs. 209-210.

${ }^{109}$ Monereo Pérez, José Luis y Molina Navarrete, Cristóbal: "Ciudadanía, solidaridad y extranjería: el derecho a la inserción de los inmigrantes"...op.cit. Monereo Pérez, José luis y Triguero Martínez, Luis Ángel: "El modelo de protección jurídico- legal del trabajador extranjero. Análisis a la luz de la reforma realizada por la Ley Orgánica 2/2009, de 11 de diciembre", en VV.AA., Monereo Pérez, José Luis (Dir.), Triguero Martínez, Luis Ángel y Fernández Avilés, José Antonio (Coords.)., Protección jurídico-social de los trabajadores extranjeros, Granada, Comares, 2010, pág. 2.
} 
grado de protección que el legislador, en cada momento conceda, el ejercicio de los mismos se reconocerá con mayor o menor grado de equiparación en relación a los españoles y, por supuesto, dentro siempre del debido respeto de los límites que se establecen por el artículo $10 \mathrm{CE}$. Por todo ello, no cabe interpretar aisladamente el artículo 13 de la $\mathrm{CE}^{110}$.

En materia de inmigración se dio un paso importante con la aprobación de la Ley Orgánica 7/1985, de 1 de julio, de derechos y libertades de los extranjeros en España ${ }^{111}$. Normativa que fue aprobada a la víspera del ingreso de España en la Comunidad Económica Europea $^{112}$ (hoy Unión Europea). De la lectura del Preámbulo de esta ley se destaca esa preocupación del legislador "... por reconocer a los extranjeros la máxima cota de derechos y libertades, cuyo ejercicio queda prácticamente equiparado al de los propios ciudadanos españoles, y para el que se establecen las mayores garantías jurídica"113. Por el contrario, la doctrina ha calificado a ésta como una ley inflexible y rígida, principalmente por su inclinación hacia el control del fenómeno migratorio en un contexto coyuntural de inmigración masiva. $\mathrm{Y}$ es que, aunque claramente se sistematizaba ahora y elevaba a rango legal toda la dispersa normativa existente en esta materia, lo cierto es que con la LO 7/1985 la nación española da cuenta del radical cambio que en sus políticas migratorias opera. Mostrándose así, frente a algunos países (como Alemania y Francia) ${ }^{114}$, como un Estado que ofrece seguridad en el marco del colectivo comunitario y que ejecuta fuertes controles de entrada en materia inmigración. De ahí que a fin de frenar la inmigración se opte, en numerosos preceptos, por la restricción en materia de derechos humanos y derechos fundamentales ${ }^{115}$. Algo realmente inconcebible en una sociedad avanzada, como es la presente.

Así, por ejemplo, destaca de esta derogada ley de extranjería de 1985 el rígido control de las entradas de inmigrantes. Se dice que debían ser siempre previa obtención del visado de trabajo en el país de origen y del permiso de trabajo al llegar a España. Cuando no se cumplieran con estos requisitos, la Ley imponía fuertes sanciones que con gran discrecionalidad se cebaban con los inmigrantes en situación de irregularidad.

\footnotetext{
110 Amaadachou Kaddur, Farah: "La prestación por desempleo desde la perspectiva del inmigrante en situación administrativa irregular, ¿trabajadores de hecho pero no de derecho?", Temas Laborales, n⿳0110, 2011, pág. 218.

${ }^{111}$ BOE núm. 158 de 3 de julio de 1985.

112 A fecha de 1 de enero del año 1986.

113 Cabe señalar, en sintonía con los artículos 10 y 13 de la CE, que el artículo 4 de la LO 7/1985 igualmente señala la idea de que los extranjeros tienen los derechos del Título I CE, en los términos establecidos en la misma ley y las demás que los desarrollasen. Sin embargo, no contiene este precepto ninguna alusión a lo que podrían ser derechos exigidos por la dignidad humana (vida e integridad, libertad ideológica, tutela judicial, etc.), que se daban por supuestos, y se regulaban sólo los derechos que presentaban limitaciones respecto a los españoles: la libertad de circulación por el territorio español, el derecho de reunión, el derecho de asociación, el derecho de educación y el derecho de sindicación.

${ }^{114}$ En dichos países la inmigración se había cerrado drásticamente a partir de la crisis del petróleo de 1973.

115 Monereo Pérez, José Luis y Triguero Martínez, Luis Ángel: "El modelo de protección jurídico- legal del trabajador extranjero. Análisis a la luz de la reforma realizada por la Ley Orgánica 2/2009, de 11 de diciembre"...op.cit. 
Tales medidas sancionadoras consistían en: la detención y privación de libertad del inmigrante irregular (en centros de internamiento, hasta un máximo de 40 días) para, posteriormente, asegurar la expulsión del mismo, lo que chocaba bastante con aquel plazo máximo de 72 horas de detención que se aplicaba a los nacionales.

Las condiciones para residir y trabajar legalmente en España venían recogidas en el artículo 15.1 de la LO 7/1985, en donde se decía que: "... para ejercer en ella cualquier actividad lucrativa, laboral o profesional, por cuenta propia o ajena, habrán de obtener, simultáneamente con el permiso de residencia, que expide el Ministerio del Interior, el permiso de trabajo, cuyo otorgamiento corresponderá al Ministerio de Trabajo y Seguridad Social y que tendrá una duración máxima de cinco años". Ello suponía que el trabajador extranjero recibiría en su país un contrato de trabajo enviado por un empresario español, lo que en la práctica resultaba imposible debido a que en aquellos momentos no existían relaciones suficientes para que los empresarios entraran en contacto con los trabajadores extranjeros. Por lo que, al término, éstos acababan entrando ilegalmente en España para desarrollar una actividad profesional bajo el manto de la economía sumergida ${ }^{116}$. A fin de controlar esta situación, el artículo 71.2 del Real Decreto 155/1996, por el que se aprueba el Reglamento de ejecución de la LO 7/1985 prohibía lo siguiente: "Ningún empresario podrá contratar a un extranjero que no está autorizado para trabajar en España, salvo que haya sido exceptuado de la obligación de preverse de permiso de trabajo, de acuerdo con lo previsto en el artículo 16 de la Ley Orgánica 7/1985".

El objetivo de sendas normas era distinguir entre inmigración irregular e regular, pero sin promocionar esta última. De ahí que, los primeros pronunciamientos judiciales caminaran en pro de la declaración de nulidad del contrato de trabajo cuando se daban circunstancias de irregularidad (a saber: la falta de capacidad del trabajador extranjero en situación administrativa irregular para prestar válidamente su consentimiento ${ }^{117}$ ) o se incumplían normas imperativas o de orden público ${ }^{118}$. A sensu contrario, en la jurisprudencia del Tribunal Superior de Justicia se partía de una visión más garantista e inclusiva del extranjero en situación irregular al admitir que el despido sea calificado como de improcedente, teniendo derecho el trabajador a recibir la correspondiente indemnización por despido. En este caso, si el inmigrante cumplía con el tiempo preciso para el acceso a la prestación por desempleo, 360 días, podía acceder a la protección social de nivel contributivo ${ }^{119}$. Y, no sólo, sino que para evitar el enriquecimiento injusto por parte del empresario se recurría al artículo 9.2 ET, de modo que el trabajador

\footnotetext{
${ }^{116}$ En el mejor de los casos, accedía en calidad de turistas.

117 Véanse las sentencias del Tribunal Supremo de 20 de octubre de 1986.

118 En este sentido, resulta llamativa la sentencia del Tribunal Supremo de 21 de marzo de 1997. Amaadachou Kaddur, Farah: "La prestación por desempleo desde la perspectiva del inmigrante en situación administrativa irregular, ¿trabajadores de hecho pero no de derecho?"...op.cit., 219.

119 Véase las sentencias del Tribunal Superior de Justicia de Castilla y León de 9 de marzo de 2006 (número de recurso 166/2006), País Vasco de 13 de febrero de 2007 y Cataluña de 4 de marzo de 2008.

Para un conocimiento más exhaustivo, Olarte Encabo, Sofía: "Extranjeros sin permiso de trabajo. Responsabilidad empresarial en orden a prestaciones por contingencias comunes. Especial referencia al desempleo", Actualidad Laboral, n 13, 2006, págs. 1586-1601.
} 
podía exigir, a cambio de los servicios prestados, la remuneración consiguiente a un contrato válido ${ }^{120}$.

Por su parte, el Tribunal Constitucional, en su sentencia 107/1984 (de 23 de noviembre y con número de recurso 576/1983), abordó la compleja cuestión de la inmigración a partir del estudio del artículo 13 de la CE. Así pues, aclara el Tribunal Constitucional que el hecho de exigir autorización de residencia para celebrar un contrato de trabajo válidamente no es contrario a la Constitución Española, ya que el hecho de que no haya una igualdad en cuanto al acceso al mercado de trabajo entre los nacionales y los extranjeros no significa que sea contrario a la Norma Madre ${ }^{121}$. En otras palabras, los derechos fundamentales de los extranjeros tienen carácter y garantía constitucional, pero son de configuración legal. Es por ello que el principio de igualdad no opere directamente entre españoles y extranjeros, salvo en aquellos derechos en los que la ley proporcione igual situación al inmigrante que al español ${ }^{122}$.

Durante esta primera etapa, la doctrina y orientaciones de la doctrina Constitucional propiciaron el reconocimiento de la protección por desempleo en base a una supuesta "alta presunta" o de "pleno derecho". Y es que aunque el empresario haya incumplido con sus obligaciones y haya expirado el permiso de residencia del inmigrante ${ }^{123}$, "los trabajadores comprendidos en este campo de aplicación se considerarán, de pleno derecho, en situación de alta a efectos de las contingencias por accidente de trabajo, enfermedad profesional y acceso al desempleo" ${ }^{124}$.

A este respecto, resultan llamativas dos sentencias del Tribunal Supremo, a saber: la de 21 de diciembre de 1994 (número de recurso 1466/1994) y la de 25 de septiembre de 1999 (número de recuro: 787/1999). En sendas sentencias, el Tribunal Supremo mantiene una doctrina amplia y proclive a la protección social de los trabajadores inmigrantes al indicar que, aunque un trabajador extranjero se encuentre en territorio español con permiso de residencia y con su permiso de trabajo expirado, lo que realmente le impide buscar y desempeñar otro trabajo es el permiso de trabajo. Por lo que, a fin de garantizar una inclusión del extranjero en España, resulta conveniente flexibilizar el requisito de la autorización administrativa, reconociendo así diferentes grados. De este modo, el Tribunal Supremo consolida el principio de igualdad de

\footnotetext{
${ }^{120}$ En esta línea, las sentencias del Tribunal Superior de Justicia de Cantabria de 5 de abril de 2005, País Vasco de 13 de febrero de 2007.

${ }^{121}$ Díaz Aznarte, MaTeresa: "El trabajador extranjero en situación administrativa irregular", en VV.AA., Monereo Pérez, José Luis (Dir.), Triguero Martínez, Luis Ángel y Fernández Avilés, José Antonio (Coords.), Protección jurídico-social de los trabadores extranjeros, Granada, Comares, 2010, pág. 407.

${ }^{122}$ Aja, Eliseo: "Capítulo 1. La evolución normativa sobre la inmigración"...op.cit., pág. 8.

${ }^{123}$ Charro Baena, Pilar: "Derecho a la prestación por desempleo del trabajador extranjero residente que carece de autorización de trabajo", Aranzadi Social, núm. 4, 2009.

${ }^{124}$ Fernández Avilés, José Antonio: "Los "renglones torcidos" de la política jurídica de protección por desempleo del trabajador extranjero inmigrante"...op.cit., pág. 9 en su versión digital. 
tratamiento entre nacionales y extranjeros extracomunitarios residentes en España, en materia de prestaciones por desempleo dentro del nivel contributivo ${ }^{125}$.

Empero, cabe tener en cuenta la Resolución de 11 de junio de 1996 que se dicta con motivo de la entrada en vigor de la LO 7/1985 y por la que se impuso, a las Direcciones Generales del INEM (Instituto Nacional de Empleo), de Trabajo y Migraciones, el acceso a las prestaciones por desempleo de los inmigrantes. En concreto se dispuso que los nacionales de países no pertenecientes a la Unión Europea, ni a Espacio Económico Europeo, pero que residieran legalmente en España podrían tener derecho a la protección por desempleo, tanto de nivel contributivo como asistencial, siempre que reunieran los requisitos legales exigidos por la normativa española y se inscribieran como demandantes de empleo ${ }^{126}$.

A consecuencia de la entrada en vigor de la Ley 66/1997, de 30 de diciembre, de Medidas Fiscales, Administrativas y de Orden Social ${ }^{127}$ se modificó el artículo 7.1 de la LGSS de $1994^{128}$, relativo a la "extensión del campo de aplicación", a fin de limitar el reconocimiento de las prestaciones contributivas únicamente ${ }^{129}$ a "... los españoles que residan en España y los extranjeros que residan o se encuentren legalmente en España, siempre que..." ejerzan su actividad en el territorio nacional y se encuentren incluidos en algunos de los apartados que se relacionan en el citado artículo. Ello implica dos importantes cambios ${ }^{130}$. De un lado, para el acceso a las prestaciones contributivas se prescinde del criterio de nacionalidad y, de otro, para las prestaciones no contributivas la protección variará dependiendo de la nacionalidad ${ }^{131}$. Cabe señalar que, tal previsión, se mantiene inalterada actualmente en la redacción de la LGSS de 2015.

La publicación de la Ley Orgánica 4/2000, de 11 de enero ${ }^{132}$, supuso un giro radical con respecto al anterior camino de desnaturalización y limitación de derechos fundamentales que operaba por obra de la LO 7/1985. Gracias a la LOEXIs se crea un

\footnotetext{
125 Amaadachou Kaddur, Farah: "La prestación por desempleo desde la perspectiva del inmigrante en situación administrativa irregular, ¿trabajadores de hecho pero no de derecho?"...op.cit., 220. Vela Díaz, Raquel: "La situación administrativa del trabajador/a extranjero y el derecho a la prestación por desempleo: visión desde una perspectiva de género", VI Encuentro Internacional de Investigadores en Derecho de Inmigración y Asilo, Valencia, 14 y 15 de junio de 2012. http://idh.uv.es/migralaw/PDF/Raquel_Vela_Diaz.pdf

${ }^{126}$ Rubio de Medina, María Dolores: "Inmigración irregular y protección social en los accidentes de trabajo y en la prestación por desempleo", en VV.AA., Sánchez-Rodas Navarro, Cristina (Coord)., Aspectos jurídicos de la inmigración irregular en la Unión Europea, Murcia, Laborum, 2009, pág. 73.

${ }^{127}$ BOE núm. 313 de 31 de diciembre de 1997.

${ }^{128}$ Real Decreto Legislativo 1/1994, de 20 de junio, por el que se aprueba la Ley General de la Seguridad Social.

${ }^{129}$ Véase artículo 44 de la Ley 66/1997, de 30 de diciembre, de Medidas Fiscales, Administrativas y de Orden Social.

${ }^{130}$ Rubio de Medina, María Dolores: "Inmigración irregular y protección social en los accidentes de trabajo y en la prestación por desempleo"... op.cit., págs. 73 y 74.

${ }^{131}$ Se incluyen, en este colectivo, a los españoles residentes en territorio nacional, los hispanoamericanos, los portugueses, brasileños, andorranos y filipinos residentes en territorio nacional. Respecto a los nacionales de los demás países habrá de acudirse a los instrumentos ratificados, suscritos o aprobados al efectos, o la reciprocidad tácita o expresamente reconocida.

132 Sobre derechos y libertades de los extranjeros en España y su integración social. ISSN: 2174-6419 Lex Social, vol. 11, núm. 1 (2021)
} 
estatuto claro de derechos para los extranjeros que viene a superar los problemas de la situación normativa previa. Para ello la LOEXIs articula su contenido en coherencia absoluta con la jurisprudencia constitucional y con la normativa de derecho comparado, al buscar la igualdad entre derechos de los residentes legales y de los nacionales. Se apuesta por la ampliación del elenco de derechos fundamentales de los extranjeros como instrumento de liberalización social y de adaptación a las necesidades que demanda el mercado de trabajo. En particular, se buscaba el incremento de la mano de obra en sectores de actividad poco visible y característicos del trabajo precario, tales como: la agricultura ${ }^{133}$, el hogar familiar, la construcción y el sector servicios (en general).

En esta misma línea de integración se pronuncia el Plan GRECO (Programa Global de Regulación y Coordinación de la Extranjería y la inmigración en España), en donde se erigen como objetivos principales los siguientes: "... serán pues titulares (se refiriéndose a los inmigrantes) de derechos fundamentales como personas y titulares de derechos sociales de configuración legal, como nuevos ciudadanos o nuevos vecinos de nuestras ciudades y pueblos" o "el catálogo de derechos y obligaciones que los españoles nos hemos concedido en la Constitución y en nuestras leyes es el que ha de beneficiarse a todas las personas y a sus familias cuando vienen a convivir entre nosotros como residentes y constituir así su mejor marco de integración".

De igual modo, la derogada Ley 56/2003, de 16 de diciembre, de Empleo reconoció (por primera vez) como uno de sus objetivos básicos el de "asegurar políticas adecuadas de integración laboral... (artículo 2 d)) de personas en situación o riesgo de exclusión social...". Más en concreto, el artículo 26 de la Ley de Empleo de 2003 se refiere expresamente a los inmigrantes. Hoy día el artículo 30.1 del vigente Real Decreto Legislativo 3/2015, de 23 de octubre, por la que se aprueba el texto refundido de la Ley de Empleo se refiere, en términos amplios, al fomento del empleo de inmigrantes con respecto a la legislación de extranjería u otros instrumentos que se puedan determinar en el marco del Sistema Nacional de Empleo (SNE).

En relación a los inmigrantes en situación irregular, aunque en un plano secundario, se busca garantizar el acceso a los derechos sociales fundamentales que tienen todas las personas por el hecho de serlo, por otro lado, no podrán éstos suponer un obstáculo a la capacidad estatal. Por lo que, se deja en manos del Estado la posibilidad de imponer límites a la permanencia y residencia de inmigrantes cuando su situación no sea legal en España. Se abre nuevamente así una brecha de tratamiento diferenciado jurídico-legal entre personas que, dependerá de su condición administrativa, manteniéndose en ese sentido el espíritu de las reformas y leyes anteriores ${ }^{134}$. Implícitamente la Ley trata de evitar y de eliminar, en la medida de lo posible, la inmigración irregular para lo cual

\footnotetext{
133 Amaadachou Kaddur, Farah: "La prestación por desempleo desde la perspectiva del inmigrante en situación administrativa irregular, ¿trabajadores de hecho pero no de derecho?"...op.cit., 220.

${ }^{134}$ Monereo Pérez, José Luis y Triguero Martínez, Luis Ángel: "El modelo de protección jurídico- legal del trabajador extranjero. Análisis a la luz de la reforma realizada por la Ley Orgánica 2/2009, de 11 de diciembre"...op.cit. pág. 66. Vela Díaz, Raquel: "La situación administrativa del trabajador/a extranjero y el derecho a la prestación por desempleo: visión desde una perspectiva de género"...op.cit., pág. 2. 
vincula las necesidades de nuestro mercado de trabajo a la lucha contra la inmigración irregular, reforzando así los controles, agravando el régimen sancionador y facilitando la expulsión de los extranjeros en situación administrativa irregular ${ }^{135}$.

Con la LOEXIs se pone fin al debate jurisprudencia que había propiciado el requisito de nacionalidad $^{136}$, al indicar que: "Los empleadores que contraten a un trabajador extranjero deberán solicitar y obtener autorización previa del Ministerio de Trabajo y Asuntos Sociales. La carencia de la correspondiente autorización para contratos por parte del empleador, sin perjuicio de las responsabilidades a que dé lugar, no invalidará el contrato de trabajo respecto a los derechos del trabajador extranjero" (artículo 33.3 de la LO 4/2000). Con posterioridad, el artículo 36.3 -tras la reforma operada en virtud de la LO 8/2000- quedó redactado del siguiente modo: "... La carencia de la correspondiente autorización por parte del trabajador, sin perjuicio de las responsabilidades a que dé lugar, no invalidará el contrato de trabajo respecto a los derechos del trabajador extranjero".

En consecuencia, una vez superado el criterio de nacionalidad y admitido como válido el contrato celebrado con el inmigrante irregular, cabe concederle el derecho de acceso a las prestaciones por desempleo en su nivel no contributivo ${ }^{137}$ y conforme a la doctrina de algunos Tribunales Superiores de Justicia ${ }^{138}$. En particular los argumentos a favor del reconocimiento del subsidio se basan en lo siguiente: a) el contrato de trabajo no es nulo y de él puede derivar el derecho de los extranjeros en situación irregular a la totalidad de las prestaciones de Seguridad Social a las que pudiera tener derecho; b) dado que la Ley no matiza, no podrá deducirse "in peius" una exclusión al acceso de los extranjeros a determinadas prestaciones $\mathrm{y}$, finalmente, c) no puede recaer sobre el trabajador las consecuencias del incumplimiento empresarial de solicitar y obtener la autorización de trabajo. De no ser así se estaría fomentando indirectamente el empleo de trabajadores extranjeros irregulares cuya contratación tendría un coste inferior, en comparación, a la de los trabajadores nacionales también sin afiliación y/o alta (eludiendo así su responsabilidad en el abono de las prestaciones) ${ }^{139}$.

135 Rodríguez-Piñero y Bravo-Ferrer, Miguel: "La nueva legislación de extranjería e inmigración", Relaciones Laborales: Revista Crítica de Teoría y Práctica, nº 10, 2010, págs. 107-124.

${ }^{136}$ No obstante, la doctrina de algunos Tribunales Superiores de Justicia se mantuvo contraria a esta tesis mayoritaria al considerar que el contrato de trabajo que vinculaba al extranjero irregular con el empleador es nulo de pleno derecho.

${ }^{137}$ Para un conocimiento más exhaustivo, ver De la Casa Quesada, Susana: La protección por desempleo en España. Configuración y régimen jurídico, Granada, Comares, 2008.

138 Véase las sentencias del Tribunal Superior de Justicia de Castilla y León de 9 de Marzo de 2006 (número de recurso 166/2006), País Vasco de 13 de febrero de 2007 y Cataluña de 4 de marzo de 2008.

${ }^{139}$ En este sentido, señala la doctrina científica lo siguiente: " Aunque en sentido restrictivo, los derechos a los que alude el artículo anterior se habrían de limitar al resarcimiento de los salarios pendientes y, en su caso, a la correspondiente indemnización por despido, no incluyendo la prestación por desempleo. En un plano teórico, sin embargo, al admitir este artículo de facto la circunstancia de que un extranjero no autorizado para trabajar pudiera ser empleado en España abría la posibilidad de que pudieran ser beneficiarios de la protección por desempleo". Ver Tobes Portillo, Paloma y Angoitia Grijalba, Miguel: "La protección por desempleo de los inmigrantes en España"... op.cit., pág.42. Fernández Avilés, José ISSN: 2174-6419 Lex Social, vol. 11, núm. 1 (2021) 
Con la redacción de la LO 14/2003 (y el desarrollo reglamentario introducido por RD 1041/2005) al artículo 36.3 de la LOEXIs se plantea una interpretación más restrictiva respecto al derecho a percibir determinadas prestaciones cuando el trabajador había realizado actividades laborales por cuenta ajena, sin disponer de la correspondiente autorización de residencia y trabajo en España. De forma que, con esta nueva referencia, se desvinculaba el contenido del artículo 36.3 de la LOEXIs del acceso a la Seguridad Social contributiva y asistencial que regulan los artículos 10 y 14 de la LOEXs, al indicarse que: "... la carencia de la correspondiente autorización por parte del empresario..., no invalidará el contrato de trabajo respecto a los derechos del trabajador extranjero, ni será obstáculo para la obtención de las prestaciones que pudieran corresponderle". Este lenguaje tan impreciso de la norma ha venido generando distintas opiniones doctrinales por cuanto que se desconoce si el trabajador inmigrante en situación irregular tenía derecho a percibir prestaciones derivadas tanto de contingencias comunes, como profesionales o si sólo tenía derecho a percibir aquellas derivadas de contingencias profesionales o, si por el contrario, no tenía derecho a percibir prestación $\operatorname{alguna}^{140}$.

Para las contingencias de origen profesionales, el Convenio $\mathrm{n}^{\mathrm{o}} 19$ de la OIT de 1925, sobre igualdad de trato a extranjeros en materia de indemnizaciones por accidente de trabajo indica, en el caso de las víctimas de accidentes laborales ocurridos en España o sus derechohabientes, que habrán de recibir el mismo trato dispensado que a los propios nacionales en orden a la reparación de sus efectos, sin exigir ningún requisito en cuanto a la residencia (artículo 1.2 del Convenio). Por su parte, la Recomendación $n^{\circ} 151$ de la OIT de 1975 sobre trabajadores migrantes señala, en su artículo 8.3, lo siguiente: "... los trabajadores migrantes cuya situación no sea regular o no haya podido regularizarse, deberán de disfrutar de la igualdad de trato, tanto para ellos como sus familias, en lo concerniente a los derechos derivados de su empleo o empleos anteriores en materia de remuneración, seguridad social...". De conformidad con esta argumentación, los Tribunales españoles extienden el derecho de los trabajadores inmigrantes en situación irregular a las prestaciones por accidente de trabajo y enfermedades profesionales.

Resulta necesario destacar el pronunciamiento del Tribunal Supremo en su sentencia de 9 de junio de 2003 (número de recurso 4217/2002). El Alto Tribunal reconoce el derecho de un ciudadano de nacionalidad colombiana, que trabajaba en España sin el correspondiente permiso de trabajo, al acceso a una incapacidad permanente absoluta. En concreto, el trabajador había sufrido un accidente de trabajo conduciendo el vehículo de la propia empresa. A raíz de dicho incidente, el extranjero solicita recibir asistencia sanitaria, así como las prestaciones económicas derivadas del accidente de trabajo a

Antonio: "Los "renglones torcidos" de la política jurídica de protección por desempleo del trabajador extranjero inmigrante"...op.cit., pág. 10 en su versión digital.

140 Tobes Portillo, Paloma y Angoitia Grijalba, Miguel: "La protección por desempleo de los inmigrantes en España"... op.cit., págs. 42 y 43. García Viñas, José: "Capítulo IV. La denegación del desempleo al trabajador extranjero sin permiso de residencia. Comentario a la sentencia del Tribunal Supremo de 18 de Marzo de 2008", en VV.AA., Sánchez-Rodas Navarro, Cristina (Coord)., Aspectos jurídicos de la inmigración irregular en la Unión Europea, Murcia, Laborum, 2009, págs. 83-87. 
cargo de la empresa ${ }^{141}$. Ambas prestaciones le fueron reconocidas por el Supremo al entender: 1) que la carencia de la autorización previa para trabajar no invalida el contrato de trabajo, todo ello sin perjuicio de las responsabilidades empresariales que se deriven; 2) se declara la obligación empresarial de cotizar por los extranjeros que presten servicios sin las correspondientes autorizaciones y permisos; y 3) en base al principio de automaticidad de las prestaciones, "los trabajadores comprendidos en el campo de aplicación de este Régimen General se considerarán, de pleno derecho, en situación de alta a efectos de accidentes de trabajo, enfermedades profesionales y desempleo, aunque su empresario hubiere incumplido sus obligaciones $(\ldots)^{142 "}$.

En esta misma línea, se pronuncia la sentencia del Tribunal Supremo de 7 de octubre de 2003 (número de recurso 2153/2002). Ésta declara que: "el contrato de trabajo del extranjero no autorizado -de nacionalidad colombiana- no es, en la actual legislación un contrato nulo. Y, siendo ello así no puede verse privado el trabajador de una protección que, en nuestro sistema de relaciones laborales, es inherente al contrato de trabajo y así lo ha sido siempre desde la primitiva Ley de Accidentes de Trabajo de 1900". Ambas sentencias evidencian una tendencia progresiva a la protección social de los trabajadores inmigrantes, que resulta acorde en el marco de Estado Social y de Derecho que diseña el artículo 41 de la Carta Magna. Por todo ello, aun cuando el extranjero no cuente con los preceptivos permisos legales, si ha prestado una actividad por cuenta ajena en España se considera que ha de quedar incluido en el campo de aplicación del sistema de protección social a los efectos de las contingencias por accidente de trabajo. Sin embargo, en el caso de la sentencia del Tribunal Supremo de 9 de junio de 2003 cabe tener presente una dificultad. Y es que, mientras que en segundo caso (sentencia del Tribunal Supremo de 7 de octubre de 2003) opera una equiparación con los españoles, al tratarse de un trabajador hispanoamericano cuyo país de origen ratifico el Convenio núm. 19 de la OIT, por el contrario, Ecuador no ha ratificado dicho Convenio (sentencia del Tribunal Supremo de 9 de junio de 2003) ${ }^{143}$. Para el Tribunal Supremo esta circunstancia no va a suponer impedimento a la hora de reconocer las prestaciones de Seguridad Social en base a los arts. 36.3 y 57.5.d) 16 de la LO 4/2000, junto con el art. 1.4.b) de la Orden de 28 de diciembre de 1966, pues "la reciprocidad se entenderá reconocida, en todo caso, respecto a las contingencias de accidentes de trabajo y enfermedad profesional" y, por último, el art. 2 del Convenio Adicional al de Seguridad Social Hispano Ecuatoriano de 1 de abril de $1960^{144}$ dispone que: "... que los trabajadores españoles en Ecuador y los trabajadores ecuatorianos en España estarán sujetos a las legislaciones sobre Seguridad

\footnotetext{
${ }^{141}$ Para un estudio más completo véase VV.AA., Izquierdo Escribano, Antonio (Coord)., El modelo de inmigración y los riesgos de exclusión, Madrid, Fundación Foessa, 2008, págs. 108 y siguientes.

${ }^{142}$ Véase el artículo 125.3 LGSS (95.3 del texto de 1974). El actual artículo 281 de la LGSS indica que: "La entidad gestora competente pagará las prestaciones por desempleo en los supuestos de incumplimiento de las obligaciones de afiliación, alta y de cotización, sin perjuicio de las acciones que pueda adoptar contra la empresa infractora y la responsabilidad que corresponda a esta por las prestaciones abonadas".

143 En esta misma dirección, véase las sentencias del Tribunal Supremo de 29 de septiembre de 2003 (número de recurso 3003/2002).

${ }^{144}$ Ratificado por España, BOE núm. 180/1975, de 28 de julio 1975.
} ISSN: 2174-6419

Lex Social, vol. 11, núm. 1 (2021) 
Social aplicables en los respectivos países y se beneficiarán de las mismas, así como sus familiares y derechohabientes, en iguales condiciones que los nacionales de cada uno de los países".

Esta previsión proteccionista a efectos de Seguridad Social del extranjero pronto se vio cercenada, ya que con la publicación de la Ley Orgánica 14/2003 se vuelve a modificar la LOEXIs. Considera ahora el legislador que los cambios introducidos con la LO 8/2000 no fueron suficientes, por lo que avala la necesidad de operar más cambios. En concreto: se ha de mejorar la gestión mediante la simplificación de los administrativos y del régimen jurídico de las situaciones de los extranjeros en España; así como de los instrumentos sancionadores previstos en la Ley 4/2000. Incorporando, de este modo, las disposiciones aprobadas por la Unión Europea ${ }^{145}$. Principalmente, quedaron afectados con la Ley 8/2000 todos los temas referentes a visados, residencia y contrato de trabajo. Se consideraba efectiva esta reforma en cuanto a las repercusiones que pudiera tener sobre el trabajador inmigrante carente de la autorización administrativa necesaria para desempeñar una actividad laboral. Por lo que, de un lado, se infiere ahora en la autorización de contratación al trabajador extranjero, desapareciendo el término de "extranjero no autorizado para trabajar" pero, de otro, se ratifica el carácter previo de la autorización administrativa correspondiente para trabajar. En cualquier caso, la: "... carencia de la correspondiente autorización por parte del empresario, sin perjuicio de las responsabilidades a que dé lugar, incluidas aquellas en materia de seguridad social, no invalidará el contrato de trabajo respecto a los derechos del trabajador extranjero, ni será obstáculo para la obtención de las prestaciones que pudieran corresponderle" (artículo 36.3 de la LO 14/2003). En definitiva, aunque se incrementan los requisitos de control para la obtención de los permisos de trabajo y residencia ${ }^{146}$, buscando así erradicar la inmigración irregular, lo cierto es que, por otro lado se ampara, "en principio" y a efectos de Seguridad Social a todos aquellos extranjeros que desempeñen una actividad profesional en España y que no cumplan con los requisitos legales.

Las dudas interpretativas en torno a si los inmigrantes irregulares tienen o no derecho de acceso a las prestaciones por desempleo queda resuelta por la LGSS de 1994. De

\footnotetext{
145 Además, el legislador añade una justificación más y es que entiende que se ha de reajustar los contenidos de la ley a la sentencia del Tribunal Supremo del 20 de marzo de 2003 (número de recurso 488/2003). En concreto, a través de esta sentencia se modifica el artículo 17.2 de la LOEXIs y se clarifica la reagrupación familiar, asociándola en todo caso a la solvencia económica y al trabajo. De modo que se evita la reagrupación en cadena de los ascendientes dependientes reagrupados, quienes, excepcionalmente, podrán a su vez reagruparse cuando tengan un permiso de residencia permanente y acrediten solvencia económica, junto con una autorización para trabajar. El artículo 19 establece que el cónyuge y los hijos reagrupados sólo podrán obtener autorización de residencia independiente cuando obtengan autorización para trabajar. Pero como la dependencia administrativa de los reagrupados se puede aprovechar para perpetuar situaciones de maltrato doméstico, explotación o abusos por parte de los reagrupantes, es imprescindible prever un mecanismo de acceso a documentación independiente de las personas.

146 Se precisa, en todos los casos, que para la obtención de los permisos correspondientes, constituye un requisito inexcusable que los trabajadores no se encuentren irregularmente en territorio español. Véase el Real Decreto 2393/2004, de 30 de diciembre, por el que se aprueba el Reglamento de la Ley Orgánica 4/2000, de 11 de enero, sobre derechos y libertades de los extranjeros en España y su integración social. ISSN: $2174-6419$ Lex Social, vol. 11, núm. 1 (2021)
} 
conformidad con el artículo 207 a) de la LGSS de 1994, por el que se regulan los requisitos para el nacimiento del derecho a las prestaciones incluidas en el nivel contributivo, se establece que: "Para tener derecho a las prestaciones por desempleo las personas comprendidas en el artículo 205 deberán reunir los requisitos siguientes: a) Estar afiliadas a la Seguridad Social y en situación de alta o asimilada al alta en los casos que reglamentariamente se determinen. b) Tener cubierto el período mínimo de cotización a que se refiere el apartado 1 del artículo 210 de la presente Ley, dentro de los seis años anteriores a la situación legal de desempleo o al momento en que cesó la obligación de cotizar. c) Encontrarse en situación legal de desempleo, acreditar disponibilidad para buscar activamente empleo y para aceptar colocación adecuada a través de la suscripción del compromiso de actividad, al que se refiere el artículo 231 de esta Ley. (...)".

Una parte de la doctrina interpreta que la capacidad de trabajar a la que hace referencia la LGSS de 1994 debe entenderse referido exclusivamente a la capacidad jurídica por edad o por aptitudes físicas o psíquicas para el trabajo y no a la situación legal o ilegal del trabajador ${ }^{147}$. Sin embargo, la mayoría de la doctrina científica ${ }^{148}$ se inclina por pensar que el precepto está excluyendo a los inmigrantes irregulares, pues difícilmente estos requisitos pueden ser cumplidos por un trabajador en situación irregular administrativa en España ${ }^{149}$.

Finalmente, el Tribunal Supremo en las emblemáticas sentencias de 18 de marzo de 2008 (número de recurso 800/2007) y de 12 de noviembre de 2008 (número de recurso 3117/2007) se pronuncia con respecto a la posibilidad o no de acceso a la prestación por desempleo de los inmigrantes irregulares ${ }^{150}$. Queda confirmado y unificado, con estas sentencias, el criterio interpretativo restrictivo según el cual todas las prestaciones del Sistema de Seguridad Social no son extensibles a los extranjeros que residen y trabajan

\footnotetext{
147 Tobes Portillo, Paloma y Angoitia Grijalba, Miguel: "La protección por desempleo de los inmigrantes en España"... op.cit., págs. 42 y 43. García Viñas, José: "Capítulo IV. La denegación del desempleo al trabajador extranjero sin permiso de residencia. Comentario a la sentencia del Tribunal Supremo de 18 de Marzo de 2008"... op.cit., págs. 83-87.

148 González Ortega, Santiago: "El derecho de los extranjeros extracomunitarios en situación irregular a prestaciones de Seguridad Social derivadas de contingencias comunes"... op.cit. Charro Baena, Pilar: "El derecho a la Seguridad Social de los solicitantes y beneficiarios de protección internacional"...op.cit. De la Casa Quesada, Susana: La protección por desempleo en España. Configuración y régimen jurídico...op.cit. Rubio de Medina, María Dolores: "Inmigración irregular y protección social en los accidentes de trabajo y en la prestación por desempleo"...op.cit., pág. 81. Amaadachou Kaddur, Farah: "La prestación por desempleo desde la perspectiva del inmigrante en situación administrativa irregular, ¿trabajadores de hecho pero no de derecho?"...op.cit., pág. 225.

149 Cabe tener presente que en la protección por desempleo, en su nivel contributivo, entre otros requisitos, se exige en su devengo un período mínimo de cotización a la Seguridad Social, requisito que sólo puede cumplirse en el caso de que el trabajador extranjero se encuentre en España en situación regular. Aparte, uno de los requisitos inexcusables para la obtención del correspondiente permiso de trabajo es que el trabajador extranjero no se encuentre en situación irregular en España.

${ }^{150}$ Véase Sempere Navarro, Antonio Vicente: "El trabajo de los extranjeros en la jurisprudencia", Revista Castellano-Manchega de Ciencias Sociales, $\mathrm{n}^{\circ} 17,2014$, págs. 25-28. 
en situación irregular ${ }^{151}$, pese a que el contrato pueda considerarse válido. Concretamente, en la sentencia del Tribunal Supremo de 18 de marzo de 2008 se indica $^{152}$, tras un completísimo repaso a las vicisitudes de la legislación de extranjería y a los pronunciamientos judiciales precedentes, que la solución judicial que hasta ahora había justificado la extensión de la protección por accidente de trabajo a los inmigrantes irregulares no resulta ya de aplicación (se refiere a las medida que en los Convenios 19 de la OIT, sobre igualdad de trato en materia de accidentes de trabajo, de 1925, y 97, sobre los trabajadores migrantes, de 1949, así como la Recomendación 151, sobre los trabajadores migrantes de 1975). El Supremo basa su razonamiento en un triple motivo $^{153}$ : 1) el Convenio número 19 de la OIT no se refiere a desempleo (y, por extensión, tampoco el resto de normas de la OIT); 2) el Convenio ${ }^{\circ} 97$ de la OIT sólo se aplican a los extranjeros en situación regular; pero además 3) cabe recordar que tanto los Convenios, como la Recomendación 151 de la OIT no son vinculantes.

Conforme a esta doctrina, los inmigrantes que estén en situación irregular en España: no tienen derecho a cobrar la prestación por desempleo, aunque hayan trabajado por cuenta ajena. Y es que al carecer el extranjero de la condición de residente legal, a juicio del Tribunal Supremo, no puede cumplirse con las exigencias que fijan las leyes para la obtención y disfrute de la prestación por desempleo ${ }^{154}$, las cuales se concretan en la aptitud y voluntad para obtener una colocación. En cambio, cuando el extranjero no dispone de la autorización de residencia, el art. 36.3 LOEXIs sólo permitiría acceder a los servicios y prestaciones sociales de carácter básico (artículo 14.3 de la LOEXIs), entre los que se encuentran la asistencia sanitaria y la asistencia social, ambas competencias de las Comunidades Autónomas.

Aunque la LOEXIs tiene por finalidad fomentar la integración de los extranjeros en España, el Tribunal Supremo sienta ahora una doctrina poco favorable a la protección social de los inmigrantes irregulares en España al afirmar ${ }^{155}$ : a) en primer lugar, que el reconocimiento de la protección por desempleo al extranjero en situación irregular en España supondría, entre otras cosas, no sólo ampliar la cobertura a todas las prestaciones de la Seguridad Social, sino también y, como consecuencia de ello, "quitar incentivos al ciudadano que acude a los complejos trámites administrativos para conseguir una autorización de residencia y trabajo"; y, b) en segundo lugar, la concesión

\footnotetext{
151 Monereo Pérez, José Luis y Vila Tierno, Francisco: "La (des)protección social del trabajador extranjero en situación irregular. La incidencia de las autorizaciones administrativas previas respecto al reconocimiento de la prestación por desempleo"... op.cit., pág. 1082.

152 Véase Giráldez Méndez, Rita: "El derecho a la prestación por desempleo de los extranjeros en situación irregular. Comentario a la Sentencia del Tribunal Supremo de 18 de marzo de 2008", Dereito: Revista Xurídica da Universida de de Santiago de Compostela, Vol. 18, nº 2, 2009, págs. 241-258.

${ }^{153}$ Rodríguez Cardo, Iván Antonio: "Extranjeros en situación irregular: derechos laborales y de Seguridad Social tras las últimas decisiones del Tribunal Supremo y del Tribunal Constitucional"...op.cit.

154 Monereo Pérez, José Luis y Vila Tierno, Francisco: "La (des)protección social del trabajador extranjero en situación irregular. La incidencia de las autorizaciones administrativas previas respecto al reconocimiento de la prestación por desempleo"... op.cit., págs. 1082-1083.

155 González Ortega, Santiago: "El derecho de los extranjeros extracomunitarios en situación irregular a prestaciones de Seguridad Social derivadas de contingencias comunes"... op.cit. pág. 276. 
de la prestación por desempleo a los extranjeros sin papeles "implicaría la creación judicial de una especie de regularización, encubierta y en espiral, porque, de acuerdo con la Ley de Extranjería, no podrían ser expulsados mientras recibiesen esta prestación".

Esta última doctrina del Tribunal Supremo (y que recogen las sentencias de 12 de marzo y 18 de noviembre de 2018) ha causado un gran impacto en el sistema de políticas migratorias. De ahí que en el año 2009 haya entrado en vigor una nueva regulación en materia de extranjería. Se trata de la reforma que a la LOEXIs opera a través de la LO 2/2009, de 11 de diciembre ${ }^{156}$.

En el mismo Preámbulo de la LO 2/2009 se pone de manifiesto las constantes tiras y afloja que, en la regulación jurídica del fenómeno migratorio, ha tenido la jurisprudencia del Tribunal Constitucional. De ahí que, aras de aunar esfuerzos y mejorar la legislación vigente conforme a lo dispuesto por las Directivas Europeas y la realidad social, se modifica nuevamente la LOEXIs. Los objetivos principales que se persiguen son los siguientes: establecer un marco de derechos y libertades de los extranjeros que garantice a todos el ejercicio pleno de los derechos fundamentales, perfeccionar el sistema de canalización legal y ordenada de los flujos migratorios laborales reforzando la vinculación de la capacidad de acogida de trabajadores inmigrantes a las necesidades del mercado de trabajo, aumentar la eficacia contra la inmigración irregular... etcétera. Para ello, esta LO 2/2009 delimita y define el nuevo marco normativo regulador para todos los extranjeros en situación regular e irregular en España.

Al igual que con las anteriores modificaciones a la LOEXIs, se pretende fomentar la integración de la población inmigrante en la nación española, al tiempo que se controlan ordenadamente los flujos de entrada y salida. El objetivo que tanto obsesiona al legislador, nuevamente, se centra en la lucha contra la inmigración ilegal. Para ello endurece los requisitos de acceso de los extranjeros al mercado laboral como solución a la situación de crisis económica, de forma que subordina las políticas migratorias a las de políticas de empleo ${ }^{157}$. Olvidando esa condición de "ciudadanía inclusiva" que tanto aspira a lograrse a nivel europeo e internacional, al priorizar el cumplimiento de los requisitos administrativos para así determinar la regulación de derechos sociales fundamentales de los trabajadores extranjeros en España. De un modo muy contundente y específico, la LO 2/2009 reconoce a los trabajadores en situación irregular las prestaciones derivadas de los convenios internacionales compatibles con su situación administrativa (esto es, las generadas por contingencias profesionales) y niega expresamente las prestaciones por desempleo. En efecto, el controvertido precepto legal

\footnotetext{
${ }^{156}$ BOE núm. 299 de 12 de diciembre de 2009.

157 Charro Baena, Pilar: "Migrantes (I): Política de empleo y política de inmigración", en VV.AA., Monereo Pérez, José Luis; Fernández Bernat, Juan Antonio y López Insua, Belén del Mar (Dirs y Coords)., Las políticas activas de empleo: Configuración y estudio de su regulación jurídica e Institucional, Navarra, Aranzadi, 2016, págs. 675-679.
} 
36.5 de la LOEXIS (antes 36.3) así lo dispone en su nueva redacción: "La carencia de la autorización de residencia y trabajo, sin perjuicio de las responsabilidades del empresario a que dé lugar, incluidas las de seguridad social, no invalidará el contrato de trabajo respecto a los derechos del trabajador extranjero, ni será obstáculo para la obtención de las prestaciones derivadas de supuestos contemplados por los convenios internacionales de protección a los trabajadores u otras que pudieran corresponderle, siempre que sean compatibles con su situación. En todo caso, el trabajador que carezca de autorización de residencia y trabajo no podrá obtener prestaciones por desempleo. Salvo en los casos legalmente previstos, el reconocimiento de una prestación no modificará la situación administrativa del extranjero". Claramente, el legislador está dando un toque de atención a la doctrina judicial al afirmar, primero, que no cabe interpretación favorable al respecto y, segundo, que el disfrute de una prestación por parte del inmigrante irregular no modificará la situación administrativa de éste ${ }^{158}$.

Por razones paradójicas y completamente opuestas al principio de igualdad de trato, esta misma teoría resulta de aplicación también a los trabajadores transfronterizos no comunitarios que, residiendo en zona limítrofe, desarrollen su actividad en España y regresen diariamente a su Estado de origen. A pesar de que estos trabajadores quedan encuadrados en la aplicación del principio "lex loci laboris" y desarrollan una actividad profesional en la nación española, en la práctica se produce una exclusión legal del marco de aplicación del sistema de protección social (en concreto, el desempleo) ${ }^{159}$.

El artículo 43.1 de la LOEXIs (tras la reforma de la LO 2/2009), en conexión con el "Derecho a la Seguridad Social y a los Servicios Sociales" que esboza el artículo 14.1 de este mismo texto legal -para los extranjeros (en general)-, es contundente al respecto al indicar: "1. Los trabajadores extranjeros que, residiendo en zona limítrofe, desarrollen su actividad en España y regresen a su lugar de residencia diariamente deberán obtener la correspondiente autorización administrativa (para trabajar) ...". En definitiva, los trabajadores transfronterizos podrán acceder a las prestaciones de Seguridad Social en igualdad de condiciones a los nacionales, empero "... si para obtener las prestaciones por desempleo, se exige la residencia en España también se debe exigir a los extranjeros transfronterizos, sin perjuicio de que esa residencia en España no se exigía para la

\footnotetext{
${ }^{158}$ En esta línea, ver las sentencias del Tribunal Supremo de 31 de enero de 2017 (número de recurso 1153/2015) y de 19 de diciembre de 2017 (número de recurso 3664/2006). Indica expresamente este tribunal: "... que el hecho de que al tiempo de la situación legal de desempleo y de la solicitud de la prestación, el trabajador se halle ya en situación regular en nuestro país, no subsana la irregularidad de los trabajos desarrollados en el periodo anterior ni permite que sean computados como susceptibles de cotización, puesto que "la regularización produce sus efectos, en lo que a esta materia se refiere, desde que tiene lugar y no posee eficacia retroactiva mientras no lo disponga la normativa de aplicación que, por lo que se ha visto, se orienta precisamente en sentido contrario".

${ }^{159}$ Burgos Goyé, $M^{a}$.Carmen: "La falacia del derecho a la prestación por la contingencia de desempleo de los trabajadores transfronterizos no comunitarios extranjeros en España", Revista de Derecho Migratorio y Extranjería, $\mathrm{n}^{\circ} 44,2017$, págs. 1 a 9 en su versión digital.
} 
percepción de otras prestaciones de Seguridad social, ni a españoles ni a extranjeros, como ocurre en otras prestaciones (sirva de paradigma las pensiones)" ${ }^{160}$.

No puede explicarse de manera lógica como desarrollando legalmente los trabajadores transfronterizos una actividad profesional en España, por el simple hecho de residir en otro Estado pierdan el derecho al acceso a la prestación por desempleo ${ }^{161}$. En cualquier caso, cabe recordar que esta relación laboral no les autoriza para residir en nuestro país, ya que lo hacen en el limítrofe (de origen) al que regresan diariamente. La autorización de trabajo de transfronteriza les habilita sólo para desempeñar una actividad profesional, por lo que en el momento en que extingue pierden la condición de trabajador transfronterizo, siendo inherente e indisoluble a la misma. Sólo se admite su prorroga mientras subsista la misma relación laboral y se mantenga esa condición. Por lo que aunque hayan sido titulares de una autorización de trabajo por cuenta ajena transfronteriza, el extranjero no genera derecho alguno para la obtención de una autorización de residencia ${ }^{162}$.

En conclusión: tras la LO 2/2009 se da muestra más que evidente del grave retroceso que en desmercantilización de la mano de obra extranjera se experimenta en el ordenamiento iuslaboral, pues se le niega el derecho de protección social a quien ha sido trabajador $\mathrm{y}$ ha contribuido con su actividad al crecimiento productivo $\mathrm{y}$ económico de nuestro país ${ }^{163}$. Resulta bastante criticable que la reforma de la legislación migratoria siga poniendo el acento en las "necesidades reales de nuestro mercado de trabajo"164, al abandonar esa idea base que motiva el nacimiento de la LOEXIs, esto es, la integración de las personas inmigrantes. A este respecto, el desempleo constituye una magnífica fórmula que no sólo cumple con los cometidos de política migratoria "ideal" y de políticas de empleo propias de todo Estado de Bienestar

\footnotetext{
${ }^{160}$ Burgos Goyé, Ma .Carmen: "La falacia del derecho a la prestación por la contingencia de desempleo de los trabajadores transfronterizos no comunitarios extranjeros en España"... op.cit., pág. 6 en su versión digital.

${ }^{161}$ Márquez Prieto, Antonio: "La problemática extensión de las prestaciones españolas no contributivas a los ciudadanos del Magreb", en VV.AA., Pensiones Sociales. Problemas y alternativas: IX Congreso Nacional de Derecho del Trabajo y de la Seguridad Social, Madrid, Ministerio de Trabajo e Inmigración. Subdirección General de Información Administrativa y Publicaciones, 1999.

162 Burgos Goyé, $\mathrm{M}^{\mathrm{a}}$.Carmen: "Trabajadores transfronterizos y prestación transnacional de servicios", en VV.AA., Monereo Pérez, José Luis; Fernández Avilés, José Antonio y Triguero Martínez, Luis Ángel (Dirs), Comentario Sistemático al Reglamento de Extranjería, Inmigración e Integración Social (LO 4/2000 y RD 557/2011), Granada, Comares, 2012. Burgos Goyé, $M^{\mathrm{a}}$.Carmen: "La falacia del derecho a la prestación por la contingencia de desempleo de los trabajadores transfronterizos no comunitarios extranjeros en España"... op.cit., pág. 6 en su versión digital.

163 Monereo Pérez, José Luis y Triguero Martínez, Luis Ángel: "El modelo de protección jurídico- legal del trabajador extranjero. Análisis a la luz de la reforma realizada por la Ley Orgánica 2/2009, de 11 de diciembre"...op.cit. pág. 66. Triguero Martínez, Luis Ángel: "La construcción del nuevo paradigma del derecho a la protección por desempleo de los trabajadores extranjeros irregulares: las SSTS de 18 de marzo, de 12 de noviembre y el anteproyecto de la ley de reforma de la LO 4/2000, de 19 de diciembre, de 2008", Aranzadi Social, Vol. 1, nº 21, 2009, págs. 73-104.

164 Molina Navarrete, Cristóbal: "Inmigración, empleo y mercado de trabajo: La inmigración económica extranjera en tiempos de crisis", VV.AA., Maroto Jiménez, Francisco (Coord.), La inmigración a Europa: Hacia un nuevo futuro, Jaén, Literalia, 2010, pág. 17.
} 
Social ${ }^{165}$, sino que es más, permite hacer justicia a los principios mismos que determinan el surgimiento del sistema de Seguridad Social y, por ende, de la protección de todos los "ciudadanos" frente a las situaciones de necesidad (Seguridad Social "universal"- todas las personas sin apego a "territorio, ni banderas"-). Se trata ésta de una percepción de la realidad que ya estaba asentada con los máximos teóricos de la política de empleo en el Estado Social contemporáneo: Keynes y Beverigde, para los cuales la política de empleo debía conectarse con esa responsabilidad que se les imponen a los poderes públicos de garantía de un equilibrio satisfactorio en el mercado de trabajo y en la protección social de las personas que trabajan o se encuentran desempleadas. Por todo ello, las políticas de empleo y la protección por desempleo se insertan en el programa constitucional inherente a la forma política de cualquier Estado Social y democrático de Derecho ${ }^{166}$.

\subsection{Nivel asistencial y desprotección de los trabajadores inmigrantes}

\subsubsection{El Nivel asistencial básico}

Como ya se ha señalado más arriba, los inmigrantes irregulares quedan excluidos igualmente del derecho al acceso al nivel asistencial por desempleo, pues conforme al artículo 274.1 letras a) y b) de la LGSS se indica que: "1. Serán beneficiarios del subsidio los desempleados que, figurando inscritos como demandantes de empleo durante el plazo de un mes, sin haber rechazado oferta de empleo adecuada ni haberse negado a participar, salvo causa justificada, en acciones de promoción, formación o reconversión profesionales, carezcan de rentas en los términos establecidos en el artículo siguiente y se encuentren en alguna de las siguientes situaciones: a) Haber agotado la prestación por desempleo y tener responsabilidades familiares. b) Haber agotado la prestación por desempleo, carecer de responsabilidades familiares y ser mayor de cuarenta y cinco años de edad en la fecha del agotamiento... etcétera".

El artículo 274 en sus apartados 2, 3 y 4 de la LGSS distingue tres posibles situaciones:

A) La de los liberados de prisión que no tenga derecho al nivel contributivo por desempleo y hubiesen sido privados de libertad por un periodo superior a seis meses ${ }^{167}$.

\footnotetext{
165 Tal y como a ella se refiere la actual Ley de Empleo de 2015, pero también (y, por primera vez) la antigua Ley 56/2003, de 16 de diciembre. Charro Baena, Pilar: "Migrantes (I): Política de empleo y política de inmigración"... op.cit., pág. 682.

${ }^{166}$ Monereo Pérez, José Luis: "Las políticas activas de empleo. Derecho al trabajo y políticas activas de empleo en el marco de la política de empleo"... op.cit., pág. 99.

${ }^{167}$ Los párrafos segundo y tercero del artículo 274.2 incluye los siguientes supuestos: "1. Los menores liberados de un centro de internamiento en el que hubieran sido ingresados como consecuencia de la comisión de hechos tipificados como delito, siempre que, además de haber permanecido privados de libertad por el tiempo antes indicado, en el momento de la liberación sean mayores de dieciséis años. 2) Las personas que hubiesen concluido un tratamiento de deshabituación de su drogodependencia, siempre que el mismo hubiera durado un período superior a seis meses y hayan visto remitida su pena privativa de libertad en aplicación de lo previsto en el artículo 87 del Código Penal y 3) Los liberados de prisión que hubieran sido condenados por la comisión de los delitos relacionados en los párrafos a), b), c) o d) ISSN: 2174-6419 Lex Social, vol. 11, núm. 1 (2021)
} 
B) Los parados que "... se hallen en situación legal de desempleo y no tengan derecho a la prestación contributiva, por no haber cubierto el período mínimo de cotización, podrán obtener el subsidio siempre que: 1) hayan cotizado al menos tres meses y tengan responsabilidades familiares. 2) Hayan cotizado al menos seis meses, aunque carezcan de responsabilidades familiares".

C) Los trabajadores mayores de cincuenta y dos años, aun cuando no tengan responsabilidades familiares, siempre que hayan cotizado por desempleo al menos durante seis años a lo largo de su vida laboral y acrediten que, en el momento de la solicitud, reúnen todos los requisitos, salvo la edad, para acceder a cualquier tipo de pensión contributiva de jubilación en el sistema de la Seguridad Social ${ }^{168}$.

Estos dos últimos supuestos que plantean el apartado 3 y 4 del artículo 274 de la LGSS no ofrecen dudas interpretativas, pues queda claro que se aplica plenamente la doctrina del Tribunal Supremo de 2008 (antes expuesta). Es decir, que sólo podrán beneficiarse de esta situación los inmigrantes en situación regular en España ${ }^{169}$ que figuren como demandantes de empleo, no hubiesen rechazado una oferta de empleo y no se hubiesen negado injustificadamente a participar en acciones de formación, promoción o reconversión profesional. Aparte el solicitante debe carecer de rentas (sea cual sea su naturaleza) superiores al 75\% del Salario Mínimo Interprofesional, excluida la parte proporcional de dos pagas extraordinarias. Las rentas se computarán por su rendimiento íntegro o bruto. Ahora bien, respecto al supuesto concreto que enuncia el nuevo apartado 4 se indica que será requisito obligatorio, para el acceso a este nivel asistencial, haber cumplido la edad de 52 años. Si se cumplen con los requisitos que enuncian los apartados 1, 2 y 3 del artículo 274, a excepción del de la edad, los solicitantes habrán de permanecer inscritos: "... ininterrumpidamente como demandantes de empleo en los

del artículo 36.2 del Código Penal solo podrán obtener el subsidio por desempleo previsto en este apartado y en el siguiente cuando acrediten, mediante la oportuna certificación de la Administración penitenciaria, los siguientes extremos: a) En el caso de los liberados de prisión condenados por los delitos contemplados en las letras a) o b) del artículo 36.2 del Código Penal, que han cumplido los requisitos exigidos en el artículo 72.6 de la Ley Orgánica 1/1979, de 26 de septiembre, General Penitenciaria. b) En el caso de los liberados de prisión condenados por los delitos contemplados en las letras c) o d) del artículo 36.2 del Código Penal, que han satisfecho la responsabilidad civil derivada del delito, considerando a tales efectos la conducta efectivamente observada en orden a reparar el daño e indemnizar los perjuicios materiales y morales, y que han formulado una petición expresa de perdón a las víctimas de su delito.

${ }^{168}$ Previsión que se incluye gracias al apartado uno del artículo 1 del Real Decreto- Ley 8/2019, de 8 de marzo, de medidas urgentes de protección social y de lucha contra la precariedad laboral en la jornada de trabajo (BOE de 12 marzo).

169 Para los inmigrantes irregulares le será de aplicación la previsión recogida en el 36.5 de la LOEXIS: "La carencia de la autorización de residencia y trabajo, sin perjuicio de las responsabilidades del empresario a que dé lugar, incluidas las de seguridad social, no invalidará el contrato de trabajo respecto a los derechos del trabajador extranjero, ni será obstáculo para la obtención de las prestaciones derivadas de supuestos contemplados por los convenios internacionales de protección a los trabajadores u otras que pudieran corresponderle, siempre que sean compatibles con su situación. En todo caso, el trabajador que carezca de autorización de residencia y trabajo no podrá obtener prestaciones por desempleo. Salvo en los casos legalmente previstos, el reconocimiento de una prestación no modificará la situación administrativa del extranjero". 
servicios públicos de empleo, podrán solicitar el subsidio cuando cumplan esa edad. A estos efectos, se entenderá cumplido el requisito de inscripción ininterrumpida cuando cada una de las posibles interrupciones haya tenido una duración inferior a noventa días, no computándose los períodos que correspondan a la realización de actividad por cuenta propia o ajena. En este último caso, el trabajador no podrá acceder al subsidio cuando el cese en el último trabajo fuera voluntario".

El subsidio para excarcelados inmigrantes, por contra, ha sido objeto de controversia en vía judicial ${ }^{170}$. La interpretación teleológica de este artículo 274.2 de la LGSS no es otra que la reinserción social del inmigrante regular ante las dificultades que encuentra para acceder al mercado de trabajo ${ }^{171}$.

En la doctrina judicial se encuentran tres argumentaciones distintas. De un lado y reiteradamente, los tribunales han denegado el subsidio asistencial a aquellos inmigrantes excarcelados en situación irregular al entender que el requisito de la tenencia de un permiso de residencia constituye requisito esencial para el acceso al desempleo (tanto en su nivel contributivo, como asistencial) ${ }^{172}$. Y es que, en este particular caso, el subsidio de excarcelados se equipara con otras prestaciones no contributivas de la Seguridad Social para las que igualmente se exige la residencia ${ }^{173}$. De otro lado, la doctrina de los Tribunales Superiores de Justicia ha afirmado que no cabe conceder el acceso al nivel asistencial en base al principio de igualdad de trato entre españoles y extranjeros cuando se incumplen los requisitos que enuncia la LGSS y la LOEXIs. En otras palabras, el requisito de residencia y de excarcelado no le habilita al inmigrante regular empadronado en España para acceder al nivel asistencial por desempleo, puesto que el empadronamiento con obligación de permanecer en España hasta la extinción completa de la pena o concesión de indulto no puede nunca sustituir la obligación legal de autorización de residencia ${ }^{174}$. Finalmente, aunque se cumpla el requisito de haber trabajado durante el tercer grado, el requisito de la residencia legal constituye requisito ineludible para el acceso a la prestación por desempleo asistencial del extranjero en España ${ }^{175}$.

\subsubsection{Rentas activas de inserción y retorno de trabajadores inmigrantes: ¿ilusión o realidad?}

En los momentos de crisis económica la acción protectora de la Seguridad Social adquiere un especial protagonismo al aumentar el número de desempleados y con ello el

170 Rubio de Medina, María Dolores: "Inmigración irregular y protección social en los accidentes de trabajo y en la prestación por desempleo"...op.cit., págs. 78 y 79.

${ }^{171}$ Sentencia del Tribunal Superior de Justicia de Cantabria de 29 de marzo del año 2002.

172 Véanse las sentencias de los Tribunales Superiores de Justicia de Sevilla (Andalucía) de 13 de abril del año 2000 y Castilla-La Mancha de 26 de octubre de 2004.

173 Sentencias del Tribunal Superior de Justicia de Cataluña de 16 de marzo de 2006 y 30 de junio de 2006.

${ }^{174}$ Ver sentencia del Tribunal Superior de Justicia de Valladolid de 9 de septiembre de 2004.

175 Sentencia del Tribunal Supremo de 2 de octubre de 2008 (recurso de suplicación $\mathrm{n}^{\circ}$ 561/07).

ISSN: 2174-6419

Lex Social, vol. 11, núm. 1 (2021) 
riesgo de sufrir exclusión social. La renta activa de inserción (RAI) forma parte, así, del campo protector de la acción por desempleo del régimen público de Seguridad Social, aun que si bien con carácter específico y diferenciado del nivel contributivo y asistencial (artículo 264.3 y Disposición Final $8^{\mathrm{a}}$ de la LGSS). La renta activa de inserción es el último nivel de la acción protectora por desempleo de la Seguridad Social en la cual se recogen todas aquellas acciones específicas de formación, perfeccionamiento, orientación, reconversión o inserción profesional en favor de los trabajadores desempleados. Actualmente, esta figura goza de una regulación propia en el Real Decreto 1369/2006, de 24 de noviembre, en donde se establece su configuración jurídica y los requisitos necesarios que el solicitante debe cumplir para obtener derecho al "programa" de renta activa de inserción.

En momentos de depresión económica, la acción protectora de la Seguridad Social se erige en un plano prioritario convirtiendo así al desempleo en la prestación estrella de todo el sistema de protección social. Precisamente es, en este contexto, en donde la generalización de los fenómenos de pobreza y exclusión social se reproducen de una forma inevitable ante la inoperancia o insuficiencia de los mecanismos sociales. Lo que, sin lugar a dudas, ha generado un intenso proceso de dualización y de desigualdad ${ }^{176}$ entre los distintos grupos o estamentos que componen la sociedad. Como en toda crisis, los colectivos más débiles han sido precisamente los más perjudicados, especialmente la porción poblacional que incluye a aquellos trabajadores con riesgo de exclusión social (a saber: jóvenes, mujeres, inmigrantes, parados de larga duración mayores de 45 años, minusválidos, personas de edad avanzadas y próximas a una edad de jubilación..., etc.).

Las deficiencias e incapacidades que dispensa el nivel contributivo de la Seguridad Social se ven agravadas ante un fenómeno que se hace, cada día, más cíclico y progresivo en el tiempo ${ }^{177}$. Lo que ha motivado el establecimiento disfuncional de medidas excluyentes, en lugar de reactivas o proactivas frente al desempleo estructural, que reproducen las previas desigualdades y exclusiones del mercado de trabajo del cual depende. Por lo que, la protección social que tanto trata de alcanzar el sistema español no sirve para evitar la pobreza, sino para discriminar a determinados colectivos en situación de necesidad ${ }^{178} \mathrm{o}$ incorporarlos al mercado de trabajo de manera irregular ${ }^{179}$.

\footnotetext{
176 Monereo Pérez, José Luis y Molina Navarrete, Cristóbal: "Un nuevo derecho social de ciudadanía: modelos normativos de "rentas mínimas de inserción" en España y en Europa", Revista de Trabajo y Seguridad Social. CEF, no 187/1998, pág. 79.

177 Monereo Pérez, José Luis y Molina Navarrete, Cristóbal: "Un nuevo derecho social de ciudadanía: modelos normativos de "rentas mínimas de inserción" en España y en Europa"...op.cit., pág. 79.

178 López Insua, Belén del Mar: "La renta activa de inserción como instrumento de lucha contra la exclusión social", en VV.AA., Rodríguez Iniesta, Guillermo y Sánchez-Rodas Navarro, Cristina (Coord)., La protección por desempleo en España. XII Congreso Nacional de la Asociación Española de Salud y Seguridad Social (AESSS), Murcia, Laborum, 2015.

179 Moreno Gené, Josep y Romero Burillo, Ana María: "Mujer, exclusión social y renta activa de inserción. Especial referencia a la protección de las víctimas de violencia de género", Revista Internacional de Organizaciones, $\mathrm{n}^{\circ}$ 3, 2009, págs. 131-156. 
La constatación de dificultades en el nivel contributivo de la Seguridad Social para atajar el problema de la pobreza y exclusión social, motivó el establecimiento tardío de las rentas activas de inserción a nivel nacional y de las rentas mínimas en el ámbito autonómico $^{180}$. Desde luego, este instrumento de protección social (que en su origen responde a técnicas de asistencia social) se ha integrado en una red última de seguridad que cubre necesidades extremas no satisfechas por la Seguridad ${ }^{181}$, aunque en su inicial carácter modesto y complementario no se cumpliera con ese ambicioso objetivo de tratamiento global de la exclusión social ${ }^{182}$.

La recepción en España del RAI se ha llevado a cabo de forma excepcional, provisional y experimental en el año 2000 ${ }^{183}$ gracias a la aprobación del "RD 236/2000, de 18 de febrero, por el que se regula el programa para la inserción laboral de los trabajadores desempleados de larga duración, en situación de necesidad, mayores de 45 años" ${ }^{184}$. Poco después, la Ley 14/2000, de 29 de diciembre, de Medidas fiscales, administrativas y del orden social, habilitó al Gobierno a regular para el año 2001 dentro de la acción protectora por desempleo y con el régimen financiero y de gestión establecido en el Capítulo V del Título III del Texto Refundido de la LGSS, el establecimiento de una ayuda específica, denominada renta activa de inserción, dirigida a los desempleados con especiales necesidades económicas y dificultades para encontrar empleo, que adquieran el compromiso de realizar actuaciones favorecedoras de su inserción laboral. Posteriormente, la Ley 45/2002, de 12 de diciembre, de medidas urgentes para la reforma del sistema de protección por desempleo y mejora de la ocupabilidad, introdujo

\footnotetext{
180 "Ante la constatación de las dificultades de este nivel contributivo de la Seguridad Social a la hora de abarcar la problemática suscitada por las nuevas formas de pobreza y de exclusión social, se produjo una reacción para intentar proteger a colectivos en situación de necesidad anteriormente huérfanos de protección. En este sentido, se previó una pensión no contributiva de jubilación, una de invalidez y una de prestación por hijo a cargo, las cuales se van a sumar a los complementos a mínimos de las pensiones contributivas y al nivel asistencial de la protección por desempleo. Ahora bien, a pesar de esta ampliación del ámbito de la protección de la Seguridad Social, todavía quedaban fuera del mismo aquellas personas entre 18 y 65 años con capacidad para trabajar o, en todo caso, con una discapacidad inferior a la exigida para acceder a la pensión no contributiva de invalidez, las cuales, en la medida en que no se hubieran incorporado al mercado de trabajo o lo hubieran hecho de forma insuficiente, no podrían acceder a las prestaciones contributivas o, en su caso, habiéndolo hecho, ya las habrían agotado, ni tampoco podrían acceder al nivel no contributivo. Es éste el vacío que era necesario cubrir, y que finalmente ha sido cubierto, aunque solamente de forma parcial, por las rentas de inserción, ya sea la renta activa de inserción estatal o las rentas mínimas autonómicas". Ver Moreno Gené, Josep y Romero Burillo, Ana María: "Mujer, exclusión social y renta activa de inserción. Especial referencia a la protección de las víctimas de violencia de género"... op.cit., pág. 134.

181 Rodríguez-Piñero y Bravo-Ferrer, Miguel: "La normalización de la Renta Activa de Inserción", Revista de Relaciones Laborales, ${ }^{\circ} 3,2007$, pág. 3.

${ }^{182}$ Monereo Pérez, José Luis y Molina Navarrete, Cristóbal: El derecho a la renta de inserción. Estudio de su régimen jurídico, Granada, Comares, 1999, pág. 55.

${ }^{183}$ Saragossà I Saragossà , Josep Vicente: "Comentarios a la renta activa de inserción"...op.cit., p. 145.

${ }^{184}$ Con este programa se incluyó una prestación económica "paliativa" de escasa cuantía, a la cual acompañaban otras medidas activas de empleo y de favorecimiento de la inserción en el mercado de trabajo de las personas más desvalidas. Para ello contaba este Plan con tres acciones novedosas: el compromiso voluntario de actividad, la tutoría individualizada de los desempleados con dificultades de inserción laboral y los talleres de empleo. Véase la Exposición de Motivos del RD 236/2000. 
en la LGSS una Disposición Final Quinta por la que se consolida la habilitación legal de esta figura.

Las sucesivas reformas de la LGSS habilitaron al Gobierno para regular de forma permanente el programa de RAI. Sin embargo, aunque todos estos programas fueron anuales y aprobados mediante reales decretos de duración limitada ${ }^{185}$, la RAI no cristalizaría su desarrollo reglamentario como norma estable y con voluntad de permanencia indefinida en el ordenamiento español hasta la promulgación del RD 1369/2006, de 24 de noviembre.

La RAI se define como una ayuda económica pública dirigida a todos aquellos desempleados con especiales necesidades económicas y dificultades para encontrar empleo que adquieran el compromiso de realizar determinadas actividades favorecedoras de su inserción laboral. Por lo que, queda claro, que son sólo dos las notas que según el RD 1396/2006 delimitan a la RAI, en primer lugar, los beneficiarios deben ser desempleados que se encuentren en situación de extrema pobreza ${ }^{186}$ y que suscriban un compromiso de actividad ${ }^{187}$, por lo que queda claro que no se trata el RAI de una red universal o generaliza, pues excluye a otros colectivos necesitados de protección (como las mujeres y los jóvenes) ${ }^{188}$; y en segundo lugar, siempre que estos sujetos cumplan con los requisitos que se especifican en el artículo 2 del RD 1369/2006 (modificados por el "RD 20/2012, de 13 de julio, de medidas para garantizar la estabilidad presupuestaria y de fomento de la competitividad"; "RD 1484/2012, de 29 de octubre, sobre las aportaciones económicas a realizar por las empresas con beneficios que realicen despidos colectivos que afecten a trabajadores de cincuenta o más años", el "Real Decreto-ley 16/2014, de 19 de diciembre, por el que se regula el Programa de

185 Cabe señalar al respecto: el RD 945/2003, de 18 de julio, por el que se regula para el año 2003 el programa de renta activa de inserción para desempleados con especiales necesidades económicas y dificultad para encontrar empleo; el RD 3/2004, de 9 de enero, por el que se prorroga para el año 2004 el programa de renta activa de inserción para desempleados con especiales necesidades económicas y dificultad para encontrar empleo, regulado por el Real Decreto 945/2003, de 18 de julio; el RD 205/2005, de 25 de febrero y el RD 1369/2006, de 24 de noviembre, por el que se regula el programa de renta activa de inserción para desempleados con especiales necesidades económicas y dificultad para encontrar empleo.

186 La LGSS parece dirigirse sólo a determinados colectivos, de carácter coyuntural y de duración limitada. Y es que, cabe criticar que el RAI se trata de una prestación que, por su naturaleza jurídica, debería aplicarse a un circulo amplio de beneficiarios de acuerdo con la finalidad para la que nació el sistema de Seguridad Social.

${ }^{187}$ El compromiso de actividad supone una manifestación del modelo del contractualización en virtud del cual el beneficiario manifiesta su plena disponibilidad para buscar empleo, trabajar participar de forma efectiva en todas aquellas acciones ofertadas por los servicios públicos de empleo y dirigidas a su inserción laboral. Ver Saragossà I Saragossà, Josep Vicente: "La coordinación entre las políticas activas de empleo y la protección económica frente al desempleo", en VV.AA, Valdés Dal-Ré, Fernando y Sobrino González, Miguel, Comentarios a la Ley de Empleo, Madrid, La Ley, 2012, págs. 522-537.

${ }^{188}$ En este sentido, Cavas Martínez, Faustino: "Protección por desempleo e inserción laboral: balance provisional de los programas de renta activa de inserción 2000/2003", Aranzadi Social, Tomo V/2003, pág. 199, valora positivamente la ampliación del ámbito subjetivo a determinadas personas apartadas del mercado de trabajo - por razón de su edad avanzada, minusvalía, retorno del extranjero o violencia de género- y que, precisamente por ello, pueden caer en la exclusión. También, Moreno Gené, Josep y Romero Burillo, Ana María: "Mujer, exclusión social y renta activa de inserción. Especial referencia a la protección de las víctimas de violencia de género"... op.cit., pág. 139. 
Activación para el Empleo" y el "Real Decreto 696/2018, de 29 de junio, por el que se aprueba el Reglamento general de la gestión financiera de la Seguridad Social") se les reconocerá una prestación económica de carácter permanente que irá destinada a promover la inserción laboral de estas personas.

La RAI se configura así como una prestación económica permanente y reconocida como un derecho subjetivo con la misma finalidad que el resto de prestaciones y subsidios por desempleo, la cual pretende hacer frente a las situaciones de necesidad reconocidas en el artículo 41 de la Constitución Española ${ }^{189}$. De ahí que la Ley enmarque al RAI dentro de las medidas de Seguridad Social, mientras que las rentas mínimas lo hacen desde el campo de la "asistencia social" ${ }^{190}$. Siendo, precisamente, éste último punto uno de los más conflictivos desde el punto de vista de las relaciones funcionales y competenciales entre las RAI y las actuaciones ejecutivas de las Comunidades Autónomas en los programas de inserción laboral ${ }^{191}$. Actualmente, el acceso de inmigrantes en situación irregular a estas rentas mínimas es nulo, pues, aunque no se exija el requisito de residencia legal, si se solicita el estar inscrito como demandante de empleo. Lo que, al término, hace imposible su acceso puesto que se exige la regularización de su situación administrativa en España.

En conclusión: el problema de la protección por desempleo no está respondiendo a la realidad que se vive, de ahí que colectivos tan necesitados (como son los inmigrantes) apenas accedan y disfruten de este último nivel de la prestación. Ello refleja que España sufre un problema económico de fondo que se convierte en casi estructural. Pese a haberse reducido los índices de desempleo entre los extranjeros, ha aumentado el número de beneficiarios de prestaciones por desempleo (prestación contributiva, subsidio, renta activa de inserción, subsidio para eventuales agrarios y programa de activación para el empleo). Por ello, uno de los retos que se plantea hoy día el sistema de protección social es del afrontar la continuidad de las rentas en períodos transicionales a través de la institucionalización y generalización del derecho a la renta básica o ingreso de ciudadanía. Se trata con ello de asegurar la continuidad de ingresos,

189 Monereo Pérez, José Luis: "El modelo de protección por desempleo: configuración técnica y orientaciones de la reforma", en VV.AA, Monereo Pérez, José Luis; Molina Navarrete, Cristóbal y Moreno Vida, $\mathrm{M}^{\mathrm{a}}$.Nieves, La Seguridad Social a la luz de sus reformas pasadas, presentes y futuras. Homenaje al profesor José Vida Soria con motivo de su jubilación, Granada, Comares, 2008, págs. 10301039.

${ }^{190}$ Monereo Pérez, José Luis y Molina Navarrete, Cristóbal: El derecho a la renta de inserción. Estudio de su régimen jurídico...op.cit., pág. 55 y siguientes. El RAI supone "una nueva técnica de protección social situada en el proceso de renovación de los sistemas de Seguridad Social contemporáneos" que, de acuerdo a sus nuevos objetivos y a su consideración como derecho social de la ciudadanía, deja de ser un instrumento externo complementario de las insuficiencias del esquema protector de la Seguridad Social, configurándose, así como una prestación de nuevo tipo que se enmarca dentro del sistema como "medida de Seguridad Social".

191 Rodríguez-Piñero y Bravo-Ferrer, Miguel: "La normalización de la Renta Activa de Inserción"...op.cit., págs. 5-8. De la Casa Quesada, Susana: "Trabajo decente y garantía de una renta mínima de inserción", en VV.AA., Monereo Pérez, José Luis; Gorelli Hernández, Juan y De Val Tena, Ángel (Dirs) y López Insua, Belén del Mar (Coord)., El trabajo decente, Granada, Comares, 2018, págs. 653-662. 
con independencia del desempeño del trabajo profesional, lo cual permite que el individuo pueda vivir dignamente gracias al percibo de un ingreso económico regular e indefinido que asegure su tutela más allá del mercado ${ }^{192}$. De este modo, se apuesta por la fijación de un sistema garantista y de satisfacción de las necesidades fundamentales del individuo en tanto éste encuentra el trabajo-empleo deseado ${ }^{193}$. Lo contrario provocaría un efecto negativo y contradictorio con los objetivos de las políticas del empleo y migratorios, al expulsar a un número importante de trabajadores a la inactividad, al subempleo o directamente, a la pobreza. Por todo ello, resulta "... criticable la tendencia a sustituir el principio de solidaridad social basado en los derechos de ciudadanía, por el reforzamiento de una suerte de derecho discrecional, basado en una ética del trabajo como eje que fundamenta el derecho a recibir la protección social" ${ }^{194}$.

\section{Rentas mínimas a nivel autonómico y propuestas de lege ferenda}

La inserción profesional de las personas más desfavorecidas ha constituido desde siempre un problema que ha preocupado al sistema comunitario. Sin embargo, no ha sido hasta la década de los años setenta cuando en la Comunidad Económica Europea se han iniciado los primeros pasos en la lucha contra la pobreza a través de la promulgación del programa piloto conocido como "Pobreza 1" (desarrollado entre 1975 y 1981). Aunque sólo se trataba de una experiencia inicial, que resultó ser bastante deficiente y poco efectiva, en algunos Estados europeos (tal como: Dinamarca, Reino Unido, Bélgica, Irlanda, Alemania y Holanda) ya se habían implantado los sistemas de rentas mínimas, a los que siguieron otros ordenamientos comunitarios durante los años ochenta (a saber: Luxemburgo y Francia). En 1985 se aprobó el programa "Acción comunitaria especifica de lucha contra la pobreza 1985-1988" o también llamado "Pobreza 2". Y, posteriormente, en 1989 se publicó el "Programa a medio plazo de medidas para la integración económica y social de las categorías de personas económica y socialmente menos favorecidas, 1989-1994", conocido como "Pobreza 3".

Los citados proyectos comunitarios de lucha contra la pobreza, aunque no lograron alcanzar los efectos prácticos deseados, sí contribuyeron a ir precisando y desarrollando, conceptualmente, lo que a finales de los años 80 se empezó a denominar como "dimensión social" de la Comunidad. Se buscaba así lograr la cohesión social y económica de la CEE, al tiempo que se fijaban unos criterios comunes para la protección social y erradicación de las diferentes situaciones de exclusión social ${ }^{195}$.

\footnotetext{
192 Monereo Pérez, José Luis: La renta mínima garantizada. De la renta mínima a la renta básica...op.cit. ${ }^{193}$ Monereo Pérez, José Luis: "Las políticas activas de empleo. Derecho al trabajo y políticas activas de empleo en el marco de la política de empleo"... op.cit., págs. 103 y 104.

194 Monereo Pérez, José Luis: "Trabajo decente y prestaciones ante situaciones de necesidad (II). Desempleo y políticas de activación e inserción", en VV.AA., Monereo Pérez, José Luis; Gorelli Hernández, Juan y De Val Tena, Ángel (Dirs) y López Insua, Belén del Mar (Coord)., El trabajo decente, Granada, Comares, 2018, pág. 607.

195 Entre finales de los años ochenta y principios de los noventa se sustituye el término "pobreza" (que para algunos Estados miembros tenía unas connotaciones políticamente inaceptables) por el de "exclusión social" (de contenido más dinámico y perspectiva multidimensional). Así pues, mientras que el concepto ISSN: 2174-6419 Lex Social, vol. 11, núm. 1 (2021)
} 
El 24 de junio de 1992 el Consejo de la Comunidad Económica Europea marcó un hito importante en esta materia al aprobar la Recomendación (92/441/CEE) "sobre los criterios comunes relativos a recursos y prestaciones suficientes en los sistemas de protección social". Normativa ésta en la que quedó definida, por primera vez y con cierta concreción, la posición comunitaria sobre la exclusión social. En dicha recomendación no sólo se invitaba a todos los Estados miembros de la CEE a desarrollar un sistema de rentas mínimas para garantizar el acceso a unos recursos y a unos servicios adecuados que aseguren la dignidad de los ciudadanos, sino que además se determinaron los elementos fundamentales para configurar los sistemas de rentas mínimas. Se disponía que: "... Las personas que estén excluidas del mercado de trabajo, ya sea por no haber podido acceder a él, ya sea por no haber podido reinsertarse en el mismo, y que no dispongan de medios de subsistencia, deben poder beneficiarse de prestaciones y de recursos suficientes adaptados a su situación personal.... Considerando que la creación de una garantía de recursos y de prestaciones es tarea de la protección social; que corresponde a los Estados miembros calificar, a tal fin, la naturaleza jurídica de las disposiciones destinadas a proporcionar dicha garantía...".

\section{Posteriormente, en el Libro Verde sobre Política Social Europea. Opciones para la} Unión [COM(93) 551 final], así como otras directrices, comunicaciones y orientaciones de la CEE (hoy Unión Europea- en adelante UE-), se vuelve de nuevo a perseverar en este propósito comunitario de garantizar unos ingresos mínimos para aquellos colectivos más vulnerables y en riesgo de exclusión social ${ }^{196}$. Por lo que no sólo se pretende poner en juego las medidas de políticas activas de empleo (formación, fomento del empleo, mejora del acceso al mercado de trabajo..., etcétera), sino que se persigue además conjugar esos mecanismos de activación con las políticas pasivas de empleo y los servicios de atención social a personas especialmente vulnerables. De modo que el recurso a los subsidios de desempleo sirva para cubrir las necesidades de aquellos más desvalidos, al tiempo que se mejora la capacidad de incorporación o retorno al sistema productivo $^{197}$. En esta línea, la actual Estrategia Europea de Empleo 2020 insiste en que esa cobertura ante la falta de rentas debe implicar, como condición para el acceso del beneficiario a la prestación por desempleo, su participación en actividades de inserción

de pobreza se limita únicamente a la carencia de recursos económicos; el de exclusión social encierra en una misma palabra todas aquellas barreras y límites que impiden, dificultad y compliquen el ejercicio de los derechos que les corresponden a todas las personas por el mero hecho de ser ciudadanos (esto es: participación en el mercado de trabajo, en los sistemas de protección social, en la educación y la cultura, el acceso a la vivienda e incluso la participación política). Ver VV.AA: "Pobreza y rentas mínimas en España y en la Unión Europea", publicado por la Confederación Sindicales de Comisiones Obreras. Secretaría de política Social, 2013, pág. 2.

http://www.aragon.ccoo.es/comunes/recursos/3/doc146821_Informe_sobre_pobreza_y_rentas_minimas.p df

196 Urteaga, Eguizki: "Las rentas mínimas en Francia", Papers: Revista de sociología, no 96, 3, 2011, págs. 959-963.

197 Saragossà I Saragossà, Josep Vicente: "Comentarios a la renta activa de inserción", en VV.AA, Roqueta Buj, Remedios (Dir) y Tatay Puchades, Carmen (Coord), Puntos Críticos en la protección por desempleo y el cese de la actividad autónoma, Navarra, Lex Nova/Aranzadi, 2015, págs. 145-146. 
laboral que completen o corrijan sus dificultades o limitaciones para el acceso al empleo. Y es que, entiende la UE, que el objetivo primordial para combatir la exclusión social y asegurar mercados de trabajo inclusivos no es otro que el sistema de ayudas económicas al desempleo, a cuyo servicio se ha de poner a disposición los instrumentos de política de empleo y de protección social. Por lo que los distintos sistemas de Seguridad Social se enfrentan ahora al reto de "combatir la pobreza para evitar los procesos de relegación o desafiliación de una parte de la población" ${ }^{198}$, lo que significa "combinar políticas de inclusión social y de dispositivos garantizando una renta mínima". En este sentido, la UE pretende evitar la diversidad de mecanismos de rentas activas configurados por el conjunto de Estados comunitarios mediante la creación de un sistema efectivo y coordinado a nivel europeo. En ese paso de las rentas mínimas de Welfare a los de mecanismos de Workfare es en donde deben entrar en escena la protección pasiva frente al desempleo, las medidas de políticas activas y los servicios de atención personal. Desde este enfoque se ha configurado en España, aunque tardíamente, frágil y de forma descoordinada, las rentas activas de inserción (a nivel estatal) y las rentas mínimas de inserción ( a nivel autonómico) ${ }^{199}$.

Cumpliendo así con los cometidos europeos, en España se ha articulado toda una red de rentas mínimas o salarios sociales autonómicos que intentan colmar las insuficiencias del sistema de protección por desempleo. En concreto, en la nación española coexisten varios sistemas de rentas de inserción o carácter asistencial: A) las RAI; B) las renta agraria, dirigida a los trabajadores del Sistema Especial para Trabajadores por Cuenta Ajena Agrarios de la Seguridad Social residentes en las Comunidades Autónomas de Andalucía y Extremadura y que no puedan disfrutar del subsidio por desempleo y, finalmente, C) las rentas mínimas de inserción (RMI) que se ponen en marcha las distintas CCAA ${ }^{200}$.

La razón que justifica el disperso entramado a nivel nacional y autonómico responde, principalmente, al rechazo de la Administración Central a implantar una renta mínima con carácter general para todo el territorio español, pero también a su empeño por

\footnotetext{
${ }^{198}$ La diversidad de dispositivos de rentas mínimas aprobados por los países de la UE ha puesto de manifiesto la necesidad de coordinar y armonizar todos estos instrumentos a través de las instituciones comunitarias. Ver Urteaga, Eguizki: "Las rentas mínimas en Francia"... op.cit., p. 963.

199 Rodríguez-Piñero y Bravo-Ferrer, Miguel: "La normalización de la Renta Activa de Inserción", Revista de Relaciones Laborales, $\mathrm{n}^{\circ}$ 3, 2007, págs. 1-3.

200 Desde la segunda mitad de los años ochenta, han sido los gobiernos regionales -asumiendo las competencias que en esta materia les confiere la Constitución- los únicos responsables del desarrollo de programas de este tipo en sus respectivos territorios. A diferencia de otras prestaciones públicas, como los servicios sociales, el diseño fijado carece de mecanismos de coordinación interterritorial para evitar posibles problemas de insuficiencia presupuestaria en las regiones con menores recursos económicos o para impedir que se generen grandes diferencias territoriales en las cuantías y en la cobertura ofrecida. Véase Monereo Pérez, José Luis: La renta mínima garantizada. De la renta mínima a la renta básica, Albacete, Bomarzo, 2018.
} 
implantar una política jurídica de mínimos específicos para colectivos carentes de protección social $^{201}$.

Se configura así una prestación de derecho subjetivo y de índole asistencial que busca un doble objetivo, esto es, fomentar la inserción socio-laboral y dar respuesta a las necesidades básicas de aquellas personas y familias carentes de recursos económicos suficientes. En su forma más típica, la RMI consiste en una prestación de naturaleza económica, integrada por la suma de una prestación mensual básica y un complemento variable, en función de los miembros que forman parte de la unidad de convivencia. Dependiendo de la CCAA en la que solicite el acceso a estas rentas mínimas o salarios sociales la denominación será distinta (a saber: salario social básico, ingreso mínimo de inserción, renta garantizada... etcétera). Como parte del Sistema público de Servicios Sociales, las RMI son una competencia exclusiva de las Comunidades y Ciudades Autónomas, por lo que cada una de ellas establece diferentes formas de acceso, requisitos exigidos, medidas complementarias su duración o su cuantía (que habrá de garantizarse por vía de Presupuestos Generales del Estado y siempre respondiendo a criterios de eficiencia y suficiencia), entre otros. La falta de homogeneidad del sistema de RMI acarrea, en la práctica, desigualdades en función de la CCAA en la que se encuentre el solicitante.

\begin{tabular}{|c|c|c|c|c|c|}
\hline Comunidad & $\begin{array}{l}\text { Nombre de } \\
\text { la renta }\end{array}$ & $\begin{array}{l}\text { Residencia } \\
\text { efectiva }\end{array}$ & Empadronamiento & $\begin{array}{l}\text { Residencia } \\
\text { legal }\end{array}$ & $\begin{array}{l}\text { Inscripción } \\
\text { como } \\
\text { demandante } \\
\text { de empleo } \\
\end{array}$ \\
\hline Andalucía & $\begin{array}{l}\text { Renta } \\
\text { mínima de } \\
\text { inserción }\end{array}$ & $\begin{array}{l}12 \text { meses con } \\
\text { excepciones }\end{array}$ & 12 meses & No & Sí \\
\hline Aragón & $\begin{array}{l}\text { Ingreso } \\
\text { Aragonés de } \\
\text { inserción }\end{array}$ & 12 meses & 12 meses & No & No \\
\hline Canarias & $\begin{array}{l}\text { Prestación } \\
\text { Canaria de } \\
\text { Inserción }\end{array}$ & 12 meses & Sí & Sí & Sí \\
\hline Cantabria & $\begin{array}{l}\text { Renta Social } \\
\text { Básica }\end{array}$ & & 12 meses & Sí. 12 meses & Sí \\
\hline $\begin{array}{l}\text { Castilla-La } \\
\text { Mancha }\end{array}$ & $\begin{array}{l}\text { Ingreso } \\
\text { Mínimo de } \\
\text { Solidaridad }\end{array}$ & $\begin{array}{l}24 \text { meses o ser } \\
\text { emigrante } \\
\text { retornado }\end{array}$ & $\begin{array}{l}24 \text { meses o ser } \\
\text { emigrante retornado }\end{array}$ & No & $\begin{array}{ll}\text { Sí, excepto las } \\
\text { víctimas de } \\
\text { violencia } \\
\text { género }\end{array}$ \\
\hline Castilla y León & $\begin{array}{l}\text { Renta } \\
\text { Garantizada } \\
\text { de } \\
\text { Ciudadanía }\end{array}$ & $\begin{array}{l}12 \text { meses con } \\
\text { excepciones }\end{array}$ & $\begin{array}{l}12 \text { meses con } \\
\text { excepciones }\end{array}$ & $\begin{array}{l}\text { Sí. } 12 \text { meses } \\
\text { con } \\
\text { excepciones }\end{array}$ & No \\
\hline Cataluña & $\begin{array}{l}\text { Renta } \\
\text { Garantizada } \\
\text { de } \\
\text { Ciudadanía }\end{array}$ & $\begin{array}{l}24 \text { meses con } \\
\text { excepciones }\end{array}$ & Sí & $\begin{array}{l}\text { Sí, con } \\
\text { excepciones }\end{array}$ & No \\
\hline
\end{tabular}

${ }^{201}$ De la Casa Quesada, Susana: "Trabajo decente y garantía de una renta mínima de inserción"...op.cit., págs. 657-659. 


\begin{tabular}{|c|c|c|c|c|c|}
\hline $\begin{array}{l}\text { Ciudad } \\
\text { Autónoma de } \\
\text { Ceuta }\end{array}$ & $\begin{array}{l}\text { Ingreso } \\
\text { mínimo de } \\
\text { inserción } \\
\text { social de } \\
\text { Ceuta } \\
\text { (IMIS) }\end{array}$ & $\begin{array}{l}\text { Miembro de la } \\
\text { Unión } \\
\text { Europea: } 1 \\
\text { año } \\
\text { No miembro } \\
\text { de la UE: } 2 \\
\text { años, con } \\
\text { excepciones }\end{array}$ & $\begin{array}{l}\text { Miembro de la Unión } \\
\text { Europea: } 1 \text { año } \\
\text { No miembro de la UE: } \\
2 \text { años, con } \\
\text { excepciones }\end{array}$ & $\begin{array}{l}\text { Miembro de } \\
\text { la Unión } \\
\text { Europea: } \\
\text { No. Para los } \\
\text { no miembros } \\
\text { de la UE: } 2 \\
\text { años, con } \\
\text { excepciones }\end{array}$ & Sí \\
\hline $\begin{array}{l}\text { Ciudad } \\
\text { Autónoma de } \\
\text { Melilla }\end{array}$ & $\begin{array}{l}\text { Ingreso } \\
\text { Melillense } \\
\text { de inserción } \\
\text { (IMI) }\end{array}$ & Sí. 60 meses & Sí. 60 meses & Sí & Sí \\
\hline $\begin{array}{l}\text { Comunidad } \\
\text { Foral de } \\
\text { Navarra }\end{array}$ & $\begin{array}{l}\text { Renta } \\
\text { Garantizada } \\
\text { de Navarra }\end{array}$ & $\begin{array}{l}24 \text { meses con } \\
\text { excepciones }\end{array}$ & Sí & No & Sí \\
\hline $\begin{array}{l}\text { Comunidad de } \\
\text { Madrid }\end{array}$ & $\begin{array}{l}\text { Renta } \\
\text { mínima de } \\
\text { inserción en } \\
\text { la } \\
\text { Comunidad } \\
\text { de Madrid }\end{array}$ & 12 meses & Sí & Sí & No \\
\hline $\begin{array}{l}\text { Comunidad } \\
\text { Valenciana }\end{array}$ & $\begin{array}{ll}\text { Renta } & \text { de } \\
\text { Garantía } & \text { de } \\
\text { ingresos } & \\
\text { mínimos } & \\
\text { (RGIM) y } \\
\text { Renta } & \text { de } \\
\text { Garantía de } & \\
\text { inclusión } & \\
\text { social } & \\
\text { (RGIS) } & \end{array}$ & $\begin{array}{lr}12 \quad \text { meses, } \\
\text { excepto } & \text { a } \\
\text { personas } & \\
\text { refugiadas } & \text { y } \\
\text { asiladas } & y \\
\text { víctimas } & \text { de } \\
\text { violencia } & \text { de } \\
\text { género o } & \text { de } \\
\text { explotación } & \\
\text { sexual o trata }\end{array}$ & $\begin{array}{l}12 \text { meses, excepto a } \\
\text { personas refugiadas y } \\
\text { asiladas y víctimas de } \\
\text { violencia de género o } \\
\text { de explotación sexual o } \\
\text { trata }\end{array}$ & No & No \\
\hline Extremadura & $\begin{array}{l}\text { Renta básica } \\
\text { extremeña } \\
\text { de inserción }\end{array}$ & $\begin{array}{l}6 \text { meses con } \\
\text { excepciones }\end{array}$ & Sí & $\begin{array}{l}\text { Sí, excepto } \\
\text { personas } \\
\text { refugiadas y } \\
\text { solicitantes } \\
\text { de asilo }\end{array}$ & No \\
\hline Galicia & $\begin{array}{ll}\text { Renta de } \\
\text { inclusión } \\
\text { social de } \\
\text { Galicia } \\
\text { (RISGA) }\end{array}$ & $\begin{array}{l}\text { Sí, con } \\
\text { excepciones }\end{array}$ & $\begin{array}{l}\text { Sí, con excepciones. } 6 \\
\text { meses }\end{array}$ & $\begin{array}{l}\text { Sí, con } \\
\text { excepciones }\end{array}$ & No \\
\hline Islas Baleares & $\begin{array}{l}\text { Renta social } \\
\text { garantizada }\end{array}$ & 36 meses & Sí & No & No \\
\hline La Rioja & $\begin{array}{l}\text { Renta de } \\
\text { Ciudadanía }\end{array}$ & 12 meses & Sí & Sí, 12 meses & Sí \\
\hline $\begin{array}{l}\text { País Vasco/ } \\
\text { Euskadi }\end{array}$ & $\begin{array}{l}\text { Renta } \\
\text { Garantizada } \\
\text { de ingresos }\end{array}$ & $\begin{array}{l}36 \text { meses con } \\
\text { excepciones }\end{array}$ & $\begin{array}{l}36 \text { meses con } \\
\text { excepciones }\end{array}$ & No & $\begin{array}{l}\text { Sí, con } \\
\text { excepciones }\end{array}$ \\
\hline $\begin{array}{l}\text { Principado de } \\
\text { Asturias }\end{array}$ & $\begin{array}{l}\text { Salario } \\
\text { social de } \\
\text { Asturias }\end{array}$ & $\begin{array}{l}24 \text { meses con } \\
\text { excepciones }\end{array}$ & Sí & $\begin{array}{l}\text { Sí, excepto } \\
\text { refugiados y } \\
\text { apátridas } \\
\text { que tengan } \\
\text { reconocida } \\
\text { tal condición }\end{array}$ & $\begin{array}{l}\text { Sí, con } \\
\text { excepciones }\end{array}$ \\
\hline $\begin{array}{ll}\text { Región } & \text { de } \\
\text { Murcia } & \\
\end{array}$ & $\begin{array}{l}\text { Renta Básica } \\
\text { de inserción }\end{array}$ & 12 meses & Sí, 12 meses & Sí, 60 meses & No \\
\hline
\end{tabular}


Tabla: Requisitos de las rentas mínimas por Comunidad Autónoma. Fuente: Ministerio de Sanidad, Consumo y Bienestar Social. Elaboración propia

Son requisitos mínimos para obtener esta ayuda los siguientes: 1) carecer de recursos económicos; 2) estar en el intervalo comprendido entre la edades máxima y mínima que fije cada comunidad autónoma, normalmente entre los 25 y los 65 años; 3) ser residente y estar empadronado durante un periodo mínimo en un municipio de la comunidad autónoma; 4) aceptar las medidas de inserción laboral, formación y orientación establecidas para esa persona y 5) estar inscrito como demandante de empleo ${ }^{202}$.

De acuerdo con estos requisitos está claro que los inmigrantes irregulares no podrán acceder a las RMI, ya que el requisito de la residencia legal condiciona el disfrute de este derecho. A buen ejemplo, las estadísticas que se elaboran anualmente por el Ministerio de Sanidad, Consumo y Bienestar Social reflejan ya una diferencia notable entre el número de españoles y extranjeros (en situación regular) que acceden a estas rentas mínimas. Ello desnaturaliza la existencia misma de estas RMI, puesto que no cumple con el objetivo previsto, esto es, paliar situaciones de emergencia social y extrema pobreza ${ }^{203}$. Aparte se desincentiva su solicitud por parte de todos aquellos inmigrantes que han contribuido al sistema, pero que no tienen acceso a estas rentas mínimas simplemente por una mera cuestión administrativa. Siendo precisamente el colectivo de los inmigrantes uno de los más vulnerables y en riesgo de pobreza, sorprende cómo se ha elevado a un plano prioritario el requisito de la "residencia" antes que el de necesidad, inserción laboral y protección social. Sobrevuela detrás de esta idea esa obsesión del legislador español por controlar y contener el gasto público. Por lo que, al final, toda esa declaración de una pretendida "protección" e inserción social queda en papel mojado.

La problemática de las RMI supone revisar todo el esquema establecido para así eliminar ese discrecional sistema de actuación autonómico. De esta forma, a nivel no contributivo, se debería crear una renta mínima garantizada nacional que evite el divergente tratamiento que, actualmente, se le concede a este derecho en función de la CCAA en la que residan los inmigrantes irregulares (y los solicitantes, en general). Las principales propuestas de revisión exigirían centrarse sobre los siguientes aspectos: una garantía unitaria e igualitaria de RMI a nivel nacional; incremento del presupuesto destinado a esta materia; cohesión territorial, incremento y mejora de la coordinación entre las distintas administraciones públicas implicadas (estatal, autonómica y local); homogeneización en los criterios de acceso, cuantías y protección a fin de posibilitar una atención adecuada a las necesidades reales de todas las personas en riesgo de exclusión social; compatibilidad en el disfrute entre las RMI y el desempeño de la

\footnotetext{
${ }^{202}$ Este requisito se exige sólo en las CCAA de La Rioja, País Vasco/Euskadi, Principado de Asturias; Andalucía, Canarias; Cantabria, Castilla-La Mancha, Comunidad Foral de Navarra y en las Ciudades Autónomas de Ceuta y Melilla.

${ }^{203}$ Monereo Pérez, José Luis: La renta mínima garantizada. De la renta mínima a la renta básica...op.cit. ISSN: 2174-6419 Lex Social, vol. 11, núm. 1 (2021)
} 
actividad laboral (cuando ésta última resulte insuficiente para poder vivir dignamente); mayor información y asistencia a la población más rechaza (en concreto: mujeres, inmigrantes, víctimas de violencia de género.... etcétera); eliminar trabas administrativas; implantar un control de calidad de las distintas situaciones (lo que no exige incrementar abusivamente las medidas de fiscalización en base a una presunción fraudulenta) y, finalmente, simplificación del procedimiento mediante la creación de una "única" oficina ${ }^{204}$.

\section{ALUSIÓN A UNA NUEVA PRESTACIÓN NO CONTRIBUTIVA: EL INGRESO MÍNIMO VITAL. LÍMITES APLICATIVOS Y EXCLUSIÓN DE INMIGRANTES IRREGULARES}

La crisis sanitaria creada por el COVID-19 y los problemas de pobreza y exclusión social (a fin de garantizar una vida digna de la persona que trabaja y de su las personas que dependen económicamente de ella) ${ }^{205}$ que ella conlleva ${ }^{206}$, determinan el nacimiento de una nueva prestación no contributiva de la Seguridad Social, esto es, el llamado ingreso mínimo vital. Esta nueva figura nace gracias al Real Decreto- Ley 20/2020, por el que se establece el ingreso mínimo vital ${ }^{207}$. El ingreso mínimo vital se configura, en particular, como un derecho subjetivo de naturaleza económica que es compatible con las ayudas que puedan establecer las comunidades autónomas. Se trata de una prestación que busca garantizar un nivel mínimo de renta que proteja, de forma diferenciada y según se dirija a un beneficiario individual o a una unidad de convivencia ${ }^{208}$, las distintas situaciones de vulnerabilidad, al permitir el tránsito desde una situación de exclusión a una de participación en la sociedad ${ }^{209}$.

${ }^{204}$ En esta línea, De la Casa Quesada, Susana: "Trabajo decente y garantía de una renta mínima de inserción"...op.cit., págs. 657-659.

${ }^{205}$ Se considera que están en situación de pobreza extrema las personas que tengan una renta inferior a 2.950 euros anuales y pobreza muy alta las personas que tengan una renta entre 2.950 y 4.350 euros anuales.

${ }^{206}$ El principal objetivo de esta figura no es otro que el de Prevenir el riesgo de pobreza y exclusión social de las personas que vivan solas o integradas en una unidad de convivencia, cuando se encuentren en una situación de vulnerabilidad por carecer de recursos económicos suficientes para la cobertura de sus necesidades básicas.

${ }^{207}$ BOE núm. 154 de 1 de junio de 2020.

${ }^{208}$ Se entiende por unidad de convivencia aquella constituida por personas que residan en un mismo domicilio y que estén unidas por vínculo matrimonial o como parejas de hecho que convivan, al menos, 5 años y que puedan acreditarlo. Se incluyen a las personas víctimas de violencia de género que hayan abandonado su domicilio habitual acompañadas de sus hijos o familiares hasta el $2^{\mathrm{a}}$ grado de consanguinidad o afinidad. De igual modo, a todas aquellas personas acompañadas de sus hijos o menores en régimen de guarda o acogimiento o familiares hasta el $2^{a}$ grado de consanguinidad o afinidad. Finalmente, se incluyen a las unidades formadas por dos o más personas de al menos 23 años y menores de 65 años que, sin mantener entre sí una relación de las indicadas anteriormente, habiten en un mismo domicilio. En este caso, se precisa de un posterior desarrollo reglamentario más exhaustivo.

${ }^{209}$ Monereo Pérez, José Luis: "La renta mínima garantizada como medida estructural del sistema de Seguridad Social en la "sociedad del riesgo", Lex Social, Vol.10, núm. 2/2020. 
La vocación decididamente universalista de la renta mínima vital plantea, sin embargo, serias dudas en cuanto a los sujetos que pueden ser titulares de la misma, pues claramente el artículo 7 de este Real Decreto- Ley 20/2020 exige que todas las personas beneficiarias, estén o no integradas en una unidad de convivencia, cumplan con cuatro requisitos clave: 1) disponer de residencia legal y efectiva en España ${ }^{210}$; 2) encontrarse en situación de vulnerabilidad económica por carecer de rentas, ingresos o patrimonio suficiente; 3) haber solicitado las pensiones o prestaciones vigentes a las que pudiera tener derecho, a excepción de los salarios sociales, rentas mínimas de inserción o ayudas análogas de asistencia social concedidas por las comunidades autónomas; 4) que el solicitante no esté trabajando, sea mayor de edad o menor emancipado. En cualquier caso, será requisito indispensable para acceder a la prestación que la persona solicitante figure como demandante de empleo.

El primer obstáculo para el acceso a esta prestación lo encuentran, de un lado, los trabajadores inmigrantes en situación administrativa irregular y, de otro, los trabajadores transfronterizos, pues claramente se exige cumplir con el requisito de residencia legal en España $^{211}$. Se trata ésta de una exclusión sorprendente en cuanto que rompe, radicalmente, con esa "supuesta" lógica proteccionista frente a las distintas situaciones de precariedad, pobreza y exclusión social ${ }^{212}$. Precisamente, los inmigrantes irregulares y los trabajadores transfronterizos forman parte de esa categoría marginal y tan característica de "trabajadores pobres" que provoca la economía sumergida e informal $^{213}$. Por ello entiendo que, negar el acceso a esta prestación, únicamente, por la falta de cumplimiento del requisito administrativo de residencia legal supone, en la práctica, rechazar el derecho a la existencia de este colectivo. ¿Dónde queda entonces la garantía de los derechos fundamentales a la dignidad y a la igualdad de trato? Esta figura no sólo rompe con esa tendencia hacia la universalidad de los derechos, sino que además provoca una desnaturalización del concepto de ciudadanía inclusiva, al tiempo que una mercantilización del estatuto jurídico de los nacionales de terceros países.

\footnotetext{
210 Conforme al artículo 19 (“Acreditación de los requisitos"): "La residencia legal en España se acreditará mediante la inscripción en el registro central de extranjeros, en el caso de nacionales de los Estados miembros de la Unión Europea, Espacio Económico Europeo o la Confederación Suiza, o con tarjeta de familiar de ciudadano de la Unión o autorización de residencia, en cualquiera de sus modalidades en el caso de extranjeros de otra nacionalidad".

${ }^{211} \mathrm{Sin}$ embargo, se establecen algunas excepciones. En efecto, no necesitan cumplir con el requisito de residencia, menores incorporados a la unidad de convivencia, personas víctimas de trata de seres humanos y de explotación sexual y mujeres víctimas de violencia de género.

212 Justamente, constituye ese el objetivo que se pretende alcanzar la Ley Orgánica 4/2000, de 11 de enero, sobre derechos y libertades de los extranjeros en España y su integración social (artículos 2 y $36.5)$.

${ }^{213}$ Monereo Pérez, José Luis: "La renta mínima garantizada como medida estructural del sistema de Seguridad Social en la "sociedad del riesgo"... op.cit., págs. 479 y 480.
} 


\section{CONCLUSIONES}

Durante estos últimos años, los cambios cualitativos que vienen experimentando las prestaciones por desempleo dan muestra más que evidente de la deficiente función que están desempeñando las políticas públicas de empleo. Tales medidas no son capaces de frenar un fenómeno que cada día se hace más persistente y crónico en el tiempo. La enorme preocupación que ha suscitado esta temática ha motivado una urgente respuesta por parte de los organismos comunitarios, quienes ya han esbozado una serie de medidas de corte represivo y paliativo que, ciertamente, son resultado de los intereses de tan sólo algunos países europeos.

Las consecuencias más directas de estas directrices orientativas y coordinadoras de las políticas de empleo comunitarias han dado ya sus frutos en España. Nuestro país ha sido tierra fértil para el proceso de modificación de la normativa de protección social, donde se ha dirigido básicamente a recortar derechos laborales, de inversión y de fomento de la estabilidad presupuestaria, en lugar de potenciar el crecimiento sobre los bienes de producción. Así pues, no sólo no se ha creado riqueza, sino que tampoco se ha diseñado un plan coherente y acorde al problema real que persiste latente en la sociedad contemporánea. Muchas han sido las críticas que ha suscitado este sinfín de reformas, dado que ha desvirtuado por completo el modelo garantista de derechos constitucionales establecidos, provocando además una regresión en la tutela de normas fundamentales protegidas al máximo nivel posible.

Pese a la gravedad del problema los Estados siguen recortando con ahínco derechos que son elementales por necesidad. A causa de esta situación se ha producido un fuerte contraste entre las diferentes capas de la sociedad, haciéndose si cabe más visible de lo que ya era. En efecto, si los pobres son cada vez más pobres y los ricos cada vez más ricos, el caldo de cultivo que alimenta el germen de la mercantilización de las relaciones laborales está más que servido. Por encima de toda medida económica se encuentra el derecho a una existencia digna, siendo los poderes públicos responsables de la consecución de esa finalidad. Ahora bien, si en lugar de fomentar políticas de "pleno empleo" y una eficaz protección por desempleo para todos los trabajadores inmigrantes, al término éstos se verán abocados a la precariedad laboral y la exclusión social.

Aunque la LOEXIs busca como objetivo prioritario la integración de todos los inmigrantes, lo cierto es que el requisito administrativo de la residencia legal dificulta enormemente el logro de ese objetivo. Se olvida así que la cobertura por desempleo constituye clave para el éxito de unas eficaces políticas de integración y protección social de inmigrantes.

La realidad presupuestaria nacional demuestra que el gasto público en protección por desempleo dirigido a los inmigrantes es deficiente. Lo que es debido a que las bases de cotización a la Seguridad Social de los trabajadores inmigrantes son menores y, por ende, las bases reguladoras, lo que demuestra una mercantilización y precarización del 
trabajo que realiza este colectivo. Las tasas de cobertura son fiel reflejo del escaso nivel de protección por desempleo que, en términos absolutos, se ofrece a los trabajadores inmigrantes. La realidad constituye fiel reflejo de la desprotección que ante esta contingencia sufre un amplio colectivo de desempleados inmigrantes. Las estadísticas manifiestan un progresivo aumento de los beneficiarios de la protección por desempleo de nivel contributivo, fruto del proceso de legalización laboral de los trabajadores inmigrantes. Sin embargo, lo cierto es que en la práctica la mayoría ya no accede al nivel asistencia y menos a las RAI (y a las RMI), pues se endurecen los requisitos. De ahí que acaben retornando a sus países o trabajando de manera precaria y/o fraudulenta.

La implantación del ingreso mínimo vital parecía ser la solución frente a las situaciones de pobreza y de exclusión social que sufren los inmigrantes irregulares (igualmente, los trabajadores transfronterizos), máxime después de esa tendencia hacia la universalidad. Sin embargo, la realidad ha demostrado, una vez más, estar bastante atrasada, evidenciando así esa falta de respeto hacia los derechos fundamentales a la vida, dignidad e igualdad de trato. Condicionar el acceso de esta nueva prestación al cumplimiento de la residencia legal y la inscripción como demandante de empleo (para lo cual resulta indispensable disponer de una autorización de residencia) resulta muy cuestionable, en tanto que pone en serio riesgo de duda la existencia de un colectivo tan vulnerable como este. Esta medida está provocando un claro efecto huida de los inmigrantes irregulares a manos de la economía sumergida para sobrevivir, al tiempo que los excluye socialmente.

El logro de un sistema adecuado de protección social resulta imprescindible para conseguir una vida digna y un derecho al trabajo decente. De lo que se trata es de que todas las personas, independientemente de su nacionalidad, tengan oportunidades para lograr un empleo productivo en condiciones de libertad, equidad, seguridad y dignidad $^{214}$. Sorprende, a este respecto, la falta de concienciación, flexibilidad y adaptación a la realidad de la normativa de Seguridad Social, de empleo y extranjería para abordar directamente el problema del desempleo y sus consecuencias.

Aparte de la falta de coordinación entre los textos normativos, se presentan unas políticas agresivas y represivas de codesarrollo que centran todos sus esfuerzos en expulsar al máximo número de inmigrantes del territorio nacional o, en su caso, arrojarlos a los brazos de la economía sumergida, como solución a la realidad que se vive. Por lo que, en lugar de crear un estatuto jurídico protector fuerte de todos los trabajadores que se aproxime al concepto de "ciudadanía inclusiva", se da un importante paso atrás al sustituir el principio de solidaridad por el de "suerte de derecho discrecional". Ello conlleva a que, en función de las circunstancias económicas y sociales predominantes, las respuestas jurídicas que se den variarán. Debiendo

${ }^{214}$ Monereo Pérez, J.L: La dignidad del trabajador. Dignidad de la persona en el sistema de Relaciones Laborales... op.cit. 
considerarse, igualmente, las opciones de política legislativa imperante (tanto a nivel nacional, como comunitario), así como la situación nacional del empleo.

Actualmente, el legislador está obviando una realidad que resulta cada vez más insostenible desde el punto de vista teleológico del sistema de Seguridad Social, pues no puede, en base a una concepción economicista, dejar desamparados a los inmigrantes que han contribuido mediante la prestación de sus servicios al crecimiento económico y productivo de nuestro país, simplemente por una cuestión administrativa de irregularidad. En efecto, esa diferenciación entre inmigrantes irregulares y regulares no sólo resulta incoherente por razones de justicia social, sino que además se erige en el principal escollo a la hora de determinar el acceso o no al sistema de protección social. Primordialmente, las carencias de este sistema se reflejan en la población inmigrante en situación irregular, quienes en la práctica vienen satisfaciendo necesidades sociales no atendidas por el Estado, ni tampoco por los nacionales. Desgraciadamente, el factor étnico está obstaculizando cada vez la integración laboral de estas personas, al tiempo que las convierte en ciudadanos de segunda clase (e incluso, tercera clase) y, por tanto, carentes de derechos fundamentales. A este respecto, la dignidad, como parámetro esencial dentro de los ordenamientos jurídicos, debe ser entendido en el sentido de que el trabajador inmigrante no es un mero instrumento de producción mercantil, sino que es ciudadano y, como tal, disfruta de todos los derechos fundamentales y de Seguridad Social que se esbozan por la normativa internacional y comunitaria.

En su conjunto, la situación coetánea puede ser calificada como de crisis del Estado democrático y de Bienestar Social. Lo que se ha materializado en la implantación de una serie de medidas de política legislativa que resultan incoherentes e insuficientes para proteger a las personas inmigrantes. Por todo ello, la doctrina científica se plantea en el marco de unas políticas legislativas de activación del pleno empleo la propuesta de implantar un sistema de rentas básicas que afronte la continuidad de las rentas, en períodos transicionales, para así garantizar el derecho a una existencia digna. En su defecto, podría ampliarse el ámbito subjetivo previsto para el ingreso mínimo vital a fin de incluir a los trabajadores inmigrantes en situación administrativa irregular y a los trabadores transfronterizos. La idea es que esta nueva figura se ajuste a la lógica universalista para la que se crea, esto es, la lucha contra las situaciones de pobreza y exclusión social. Se apuesta así por la fijación de un sistema garantista y de satisfacción de las necesidades fundamentales del individuo en tanto éste encuentra el trabajoempleo deseado ${ }^{215}$, para ello resultará esencial el papel que efectúen los servicios públicos de empleo a fin de promover la inclusión laboral de todos aquellos inmigrantes en riesgo de exclusión social. No obstante, para que pueda operar ésta última medida, primero habrá de superarse los límites que a la nacionalidad se imponen por la LOEXIs y la doctrina del Tribunal Supremo.

\footnotetext{
${ }^{215}$ Monereo Pérez, J.L: "Trabajo decente y prestaciones ante situaciones de necesidad (II). Desempleo y políticas de activación e inserción"...op.cit. 


\section{BIBLIOGRAFÍA}

Aguilera Izquierdo, Raquel: "El acceso de los inmigrantes irregulares al mercado de trabajo: los procesos de regularización extraordinaria y el arraigo social y laboral", Revista del Ministerio de Trabajo y Asuntos Sociales, nº63, 2006.

Aja, Eliseo: "Capítulo 1. La evolución normativa sobre la inmigración", en VV.AA., Aja, Eliseo y Arango, Joaquín. (Coords), Veinte años de inmigración en España. Perspectiva jurídica y sociológica (1985-2005)., Madrid, Anuario de Inmigración en España, 2005.

Álvarez Cortés, Juan Carlos y Plaza Angulo, Juan José: "El desempleo en su modalidad de pago único como ayuda a nuevos emprendedores", Temas Laborales, n 95, 2008.

Amaadachou Kaddur, Farah: "La prestación por desempleo desde la perspectiva del inmigrante en situación administrativa irregular, ¿trabajadores de hecho pero no de derecho?", Temas Laborales, nº110, 2011.

Burgos Goyé, María del Carmen: "La falacia del derecho a la prestación por la contingencia de desempleo de los trabajadores transfronterizos no comunitarios extranjeros en España", Revista de Derecho Migratorio y Extranjería, nº 44, 2017.

Burgos Goyé, María del Carmen: "Trabajadores transfronterizos y prestación transnacional de servicios", en VV.AA., Monereo Pérez, José Luis; Fernández Avilés, José Antonio y Triguero Martínez, Luis Ángel (Dirs), Comentario Sistemático al Reglamento de Extranjería, Inmigración e Integración Social (LO 4/2000 y RD 557/2011), Granada, Comares, 2012.

Cabeza Pereiro, Jaime: "El pago único de la prestación de desempleo a los inmigrantes que retornen: Primeras notas", Actualidad Laboral, n 21, 2008.

Cabeza Pereiro, Jaime: "La protección de Seguridad Social de las personas extranjeras", Actualidad Laboral, n³, 2008.

Cabeza Pereiro, Jaime: Ensayo sobre el trabajo precario y las personas vulnerables, Murcia, Laborum, 2015.

Cavas Martínez, Faustino: "Protección por desempleo e inserción laboral: balance provisional de los programas de renta activa de inserción 2000/2003", Aranzadi Social, Tomo V/2003.

Ceinos Suárez,Ángeles: El trabajo de los extranjeros en España, Madrid, La Ley, 2006.

Charro Baena, Pilar: "Derecho a la prestación por desempleo del trabajador extranjero residente que carece de autorización de trabajo", Aranzadi Social, núm. 4, 2009.

Charro Baena, Pilar: "El derecho a la Seguridad Social de los solicitantes y beneficiarios de protección internacional", en VV.AA., Monereo Pérez, José Luis y Triguero Martínez, Luis Ángel (Dirs y Coords)., Refugiados y asilados ante el modelo social 
europeo y español. Estudio técnico-jurídico y de política del Derecho, Granada, Comares, 2016.

Charro Baena, Pilar: "El trabajo de los extranjeros en España: Una lectura desde el ordenamiento laboral", Revista del Ministerio de Trabajo y Asuntos Sociales, n63, 2006.

Charro Baena, P: "Migrantes (I): Política de empleo y política de inmigración", en VV.AA., Monereo Pérez, José Luis; Fernández Bernat, Juan Antonio y López Insua, Belén del Mar (Dirs y Coords)., Las políticas activas de empleo: Configuración y estudio de su regulación jurídica e Institucional, Navarra, Aranzadi, 2016.

Charro Baena, Pilar: "Retorno voluntario de extranjeros extracomunitarios: Configuración general y medidas adoptadas en el contexto de crisis económica: La capitalización del desempleo", Revista del Ministerio de Empleo y Seguridad Social, $\mathrm{n}^{\circ}$ $105,2013$.

De la Casa Quesada, Susana: "La inserción laboral de los inmigrantes", en VV.AA., Molina Navarrete, Cristóbal (Coord)., Empleo y mercado de trabajo: nuevas demandas, nuevas políticas, nuevos derechos, Sevilla, Consejo Andaluz de Relaciones Laborales (CARL), 2004.

De la Casa Quesada, Ssusana: "Trabajo decente y garantía de una renta mínima de inserción", en VV.AA., Monereo Pérez, José Luis; Gorelli Hernández, Juan y De Val Tena, Ángel (Dirs) y López Insua, Belén del Mar (Coord)., El trabajo decente, Granada, Comares, 2018.

De la Casa Quesada, Susana: La protección por desempleo en España. Configuración y régimen jurídico, Granada, Comares, 2008.

De la Villa de la Serna, Diego: "Medidas de fomento de la retro-inmigración. Comentario al real decreto-Ley 4/2008, de 19 de septiembre y sus normas complementarias", Revista General de Derecho del Trabajo y de la Seguridad Social, $\mathrm{n}^{\mathrm{o}} 18,2008$.

Díaz Aznarte, María Teresa: "El trabajador extranjero en situación administrativa irregular", en VV.AA., Monereo Pérez, José Luis (Dir.), Triguero Martínez, Luis Ángel y Fernández Avilés, José Antonio (Coords.), Protección jurídico-social de los trabadores extranjeros, Granada, Comares, 2010.

Engisch, Karl: Introducción al pensamiento jurídico, Edición al cuidado de Monereo Pérez, José Luis, Comares, Granada, 2001.

Fernández Avilés, José Antonio: "Los "renglones torcidos" de la política jurídica de protección por desempleo del trabajador extranjero inmigrante", Revista de Derecho Migratorio y Extranjería, núm. 31, 2012.

Fernández Collados, María Belén: "Los trabajadores extracomunitarios ante el sistema español de protección por desempleo", Aranzadi Social, n¹0, 2003. 
García Murcia, Joaquín: "Desempleo", VV.AA.: Desempleo. XIV Congreso Nacional de Derecho del Trabajo y de la Seguridad Social, Madrid, Ministerio de Trabajo y Asuntos Sociales, 2004.

García- Perrote Escartín, Ignacio y Mercader Uguina, Jesús Rafael: "Extranjeros en situación irregular y responsabilidades empresariales en materia de Seguridad Social. Cambios jurisprudenciales", Justicia Laboral, nº16, 2003.

García Viñas, José: "Capítulo IV. La denegación del desempleo al trabajador extranjero sin permiso de residencia. Comentario a la sentencia del Tribunal Supremo de 18 de marzo de 2008", en VV.AA., Sánchez-Rodas Navarro, Cristina (Coord)., Aspectos jurídicos de la inmigración irregular en la Unión Europea, Murcia, Laborum, 2009.

Giráldez Méndez, Rita: "El derecho a la prestación por desempleo de los extranjeros en situación irregular. Comentario a la Sentencia del Tribunal Supremo de 18 de marzo de 2008", Dereito: Revista Xurídica da Universida de de Santiago de Compostela, Vol. 18, $\mathrm{n}^{\circ} 2,2009$.

Gómez Abelleira, Francisco Javier: "La autorización de trabajo por cuenta ajena de los extranjeros no comunitarios: los efectos de su carencia", Revista del Ministerio de Trabajo y Asuntos Sociales, $\mathrm{n}^{\circ} 63,2006$.

González Ortega, Santiago: "El derecho de los extranjeros extracomunitarios en situación irregular a prestaciones de Seguridad Social derivadas de contingencias comunes", en VV.AA., González Ortega, Santiago (Coord)., La protección social de los extranjeros en España, Valencia, Tirant Lo Blanch, 2010.

López Insua, Belén del Mar: "El fraude en las prestaciones por desempleo", Revista de Derecho de la Seguridad Social, n³, 2º Trimestre de 2015.

López Insua, Belén del Mar: "La lucha contra la precarización en el empleo desde la perspectiva de la Seguridad Social: desempleo o supervivencia en un contexto de crisis "económica" y "social", Revista IUSLabor, nº1, 2016.

López Insua, Belén del Mar: "La protección frente al desempleo de las personas emigrantes de la Unión Europea" en VV.AA., Fernández Avilés, José Antonio (Dir) y Durán Bernardino, Manuela (Coord)., Nuevas políticas jurídicas para el cambio migratorio. Tutela jurídico-social de los trabajadores emigrantes, Navarra, Aranzadi, 2017.

López Insua, Belén del Mar: La protección social de las personas inmigrantes: un modelo garantista, Barcelona, Atelier, 2020.

López Insua, Belén del Mar: "La renta activa de inserción como instrumento de lucha contra la exclusión social", en VV.AA., Rodríguez Iniesta, Guillermo y Sánchez-Rodas Navarro, Cristina (Coord)., La protección por desempleo en España. XII Congreso Nacional de la Asociación Española de Salud y Seguridad Social (AESSS), Murcia, Laborum, 2015. 
Maldonado Molina, Juan Antonio: "Pago anticipado del desempleo a los inmigrantes: ¿Fomento de empleo o del retorno?, en VV.AA., Fernández Avilés, José Antonio y Moreno Vida, María Nieves (Dirs); Ortega Pérez, Nieves, Guillén López, Enrique, Durán Ruíz, Francisco Javier y Triguero Martínez, Luis Ángel (Coord)., Inmigración y crisis económica: retos políticos y de ordenación jurídica, Granada, Comares, 2011.

Martínez-Abascal, Vicente Antonio: "Seguridad Social e inmigración: la ardua forja de una ciudadanía social plena", en VV.AA., Monereo Pérez, José Luis., Molina Navarrete, Cristóbal y Moreno Vida, María Nieves (Coords)., La Seguridad Social a la luz de sus reformas pasadas, presentes y futuras. Homenaje al Profesor José Vida Soria con motivo de su jubilación, Granada, Comares, 2008.

Mercader Uguina, Jesús Rafael: "La protección social de los trabajadores extranjeros" en VV.AA., Derechos y libertades de los extranjeros: XII Congreso Nacional de Derecho del Trabajo y de la Seguridad Social, Santander, Ministerio de Trabajo, 2001.

Molina Navarrete, Cristóbal: "Inmigración, empleo y mercado de trabajo: La inmigración económica extranjera en tiempos de crisis", VV.AA., Maroto Jiménez, Francisco (Coord.), La inmigración a Europa: Hacia un nuevo futuro, Jaén, Literalia, 2010.

Monereo Pérez, José Luis y Molina Navarrete, Cristóbal: "Un nuevo derecho social de ciudadanía: modelos normativos de "rentas mínimas de inserción" en España y en Europa", Revista de Trabajo y Seguridad Social. CEF, nº 187/1998.

Monereo Pérez, José Luis y Molina Navarrete, Cristóbal: "Ciudadanía, solidaridad y extranjería: el derecho a la inserción de los inmigrantes", en VV.AA., Monereo Pérez, José Luis, Molina Navarrete, Cristóbal y Moreno Vida, María Nieves (Dirs.), Comentario a la Constitución Socioeconómica de España, Granada, Comares, 2002.

Monereo Pérez, José Luis y Triguero Martínez, Luis Ángel: "El modelo de política jurídica de inmigración y mercado de trabajo en España", Revista de derecho Migratorio y Extranjería, no 29, 2012.

Monereo Pérez, José Luis y Triguero Martínez, Luis Ángel: "El modelo de protección jurídico- legal del trabajador extranjero. Análisis a la luz de la reforma realizada por la Ley Orgánica 2/2009, de 11 de diciembre", en VV.AA., Monereo Pérez, José Luis (Dir.), Triguero Martínez, Luis Ángel y Fernández Avilés, José Antonio (Coords.)., Protección jurídico-social de los trabajadores extranjeros, Granada, Comares, 2010.

Monereo Pérez, José Luis y Vila Tierno, Francisco: "La (des)protección social del trabajador extranjero en situación irregular. La incidencia de las autorizaciones administrativas previas respecto al reconocimiento de la prestación por desempleo", Derecho de las Relaciones Laborales, ${ }^{\circ} 11,2017$.

Monereo Pérez, José Luis: "Artículo 53. Nivel de protección", en VV.AA., Monereo Atienza, Cristina y Monereo Pérez, José Luis (Dir y Coord), La Europa de los derechos. Estudio sistemático de la Carta de los Derechos Fundamentales de la Unión Europea, Granada, Comares, 2012. 
Monereo Pérez, José Luis: "Capítulo V. El sistema español de protección por desempleo: eficacia, equidad y nuevos enfoques", en VV.AA., Rodríguez Iniesta, Gruillermo y Sánchez-Rodas Navarro, Cristóbal (Coord)., La protección por desempleo en España. XII Congreso Nacional de la Asociación Española de Salud y Seguridad Social (AESSS), Murcia, Laborum, 2015.

Monereo Pérez, José Luis: "El derecho a la Seguridad Social", en VV.AA., Monereo Pérez, José Luis; Molina Navarrete, Cristóbal y Moreno Vida, María Nieves (Dirs)., Comentario a la Constitución socio-económica de España, Granada, Comares, 2002.

Monereo Pérez, José Luis: "El modelo de protección por desempleo: configuración técnica y orientaciones de la reforma", en VV. AA, Monereo Pérez, José Luis; Molina Navarrete, Cristóbal y Moreno Vida, María Nieves, La Seguridad Social a la luz de sus reformas pasadas, presentes y futuras. Homenaje al profesor José Vida Soria con motivo de su jubilación, Granada, Comares, 2008.

Monereo Pérez, José Luis: "Las políticas activas de empleo. Derecho al trabajo y políticas activas de empleo en el marco de la política de empleo", en VV.AA., Monereo Pérez, José Luis; Fernández Bernat, Juan Antonio y López Insua, Belén del Mar (Dirs y Coords)., Las políticas activas de empleo: Configuración y estudio de su regulación jurídica e Institucional, Navarra, Aranzadi, 2016.

Monereo Pérez, José Luis: "La renta mínima garantizada como medida estructural del sistema de Seguridad Social en la "sociedad del riesgo", Lex Social, Vol.10, núm. 2/2020.

Monereo Pérez, José Luis: "Los derechos de Seguridad Social de los trabajadores migrantes: inmigración laboral y refugiados", Revista de Derecho Migratorio y Extranjería, nº41, 2016.

Monereo Pérez, José Luis: "Trabajo decente y prestaciones ante situaciones de necesidad (II). Desempleo y políticas de activación e inserción", en VV.AA., Monereo Pérez, José Luis; Gorelli Hernández, Juan y De Val Tena, Ángel (Dirs) y López Insua, Belén del Mar (Coord)., El trabajo decente, Granada, Comares, 2018.

Monereo Pérez, José Luis: El sistema de protección por desempleo en España, Valencia, Tirant lo Blanch, 1997.

Monereo Pérez, José Luis: La dignidad del trabajador. Dignidad de la persona en el sistema de Relaciones Laborales, Murcia, Laborum, 2020.

Monereo Pérez, José Luis: La renta mínima garantizada. De la renta mínima a la renta básica, Albacete, Bomarzo, 2018.

Monereo Pérez, José Luis: Las nuevas políticas de protección por desempleo y su reflejo en el sistema jurídico, Valencia, Tirant Lo Blanch, 2003. 
Monereo Pérez, José Luis; Molina Navarrete, Cristóbal; Quesada Segura, Rosa y Maldonado Molina, Juan Antonio: Manual de Seguridad Social, Decimoquinta edición, Madrid, Tecnos, 2019.

Moreno Gené, Josep y Romero Burillo, Ana María: "Mujer, exclusión social y renta activa de inserción. Especial referencia a la protección de las víctimas de violencia de género", Revista Internacional de Organizaciones, nº 3, 2009.

Montoya Melgar, Antonio: "El empleo ilegal de inmigrantes", Revista de derecho de la Unión Europea, nº17, 2009.

Olarte Encabo, Sofía: "Extranjeros sin permiso de trabajo. Responsabilidad empresarial en orden a prestaciones por contingencias comunes. Especial referencia al desempleo", Actualidad Laboral, n 13, 2006.

Rodríguez Cardo, Iván Antonio: "Extranjeros en situación irregular: derechos laborales y de Seguridad Social tras las últimas decisiones del Tribunal Supremo y del Tribunal Constitucional", Actualidad Laboral, n5, 2009.

Rodríguez-Piñero y Bravo-Ferrer, Miguel: "La normalización de la Renta Activa de Inserción", Revista de Relaciones Laborales, n 3, 2007.

Rodríguez-Piñero y Bravo-Ferrer, Miguel: "La nueva legislación de extranjería e inmigración", Relaciones Laborales: Revista Crítica de Teoría y Práctica, nº 10, 2010.

Rojo Torrecilla, Eduardo y Camas Rodas, Ferran: " Las reformas en materia de extranjería en el ámbito laboral: consolidación del modelo con reformulación de políticas, Temas Laborales, $\mathrm{n}^{\mathrm{o}}$ 104, 2010.

Roqueta Buj, Roqueta: "Las condiciones de trabajo y Seguridad Social de los extranjeros en España", Revista de Derecho Migratorio y Extranjería, nº10, 2005.

Rubio de Medina, María Dolores: "Inmigración irregular y protección social en los accidentes de trabajo y en la prestación por desempleo", en VV.AA., Sánchez-Rodas Navarro, Cristina (Coord)., Aspectos jurídicos de la inmigración irregular en la Unión Europea, Murcia, Laborum, 2009.

Rubio Velasco, Fuencisla: "Capítulo VIII. La prestación por desempleo de los extranjeros irregulares", en VV.AA., Rodríguez Iniesta, Guilermo y Sánchez-Rodas Navarro, Cristina (Coord)., La protección por desempleo en España. XII Congreso Nacional de la Asociación Española de Salud y Seguridad Social (AESSS), Murcia, Laborum, 2015.

Ruiz Cuesta, María y Muñoz Ruiz, Ana Belén: "Contrato de trabajo nulo y prestaciones de Seguridad Social", en VV.AA., Derechos y libertades de los extranjeros: XII Congreso Nacional de Derecho del Trabajo y de la Seguridad Social, Santander, Ministerio de Trabajo, 2001.

Ruiz de Huidobro de Carlos, José María: "La ley Orgánica 4/2000: historia de un desencuentro y razón de su desenfoque jurídico", Migraciones. Revista del Instituto Universitario de Estudios sobre Migraciones, nº7, 2000. 
Ruiz de Huidobro de Carlos, José María: "Notas sobre el proceso de reforma legislativa en materia de extranjería e inmigración", Revista Migraciones, núm. 4, 1998.

Sánchez Jiménez, María Ángeles: "La articulación del derecho de extranjería", en VV.AA., Sánchez Jiménez, María Ángeles (Coord)., Derecho de extranjería: un análisis legal y jurisprudencial del régimen jurídico del extranjero en España (jurisprudencia y formularios), Murcia, DM, 2005.

Saragossà I Saragossà, Josep Vicente: "Comentarios a la renta activa de inserción", en VV.AA, Roqueta Buj, Remedios (Dir) y Tatay Puchades, Carmen (Coord), Puntos Críticos en la protección por desempleo y el cese de la actividad autónoma, Navarra, Lex Nova/Aranzadi, 2015.

Saragossà I Saragossà, Josep Vicente: "La coordinación entre las políticas activas de empleo y la protección económica frente al desempleo", en VV.AA, Valdés Dal-Ré, Fernando y Sobrino González, Miguel, Comentarios a la Ley de Empleo, Madrid, La Ley, 2012.

Sempere Navarro, Antonio Vicente: "El trabajo de los extranjeros en la jurisprudencia", Revista Castellano-Manchega de Ciencias Sociales, $\mathrm{n}^{\circ}$ 17, 2014.

Taribini-Castellani Aznar, Margarita: "Los derechos de los trabajadores extranjeros: Puntos críticos", Revista del Ministerio de Trabajo y Asuntos Sociales, nº3, 2006.

Tobes Portillo, Paloma y Angoitia Grijalba, Miguel: "La protección por desempleo de los inmigrantes en España", Revista del Ministerio de Trabajo y Asuntos Sociales, nº61, 2006.

Triguero Martínez, Luis Ángel: "La construcción del nuevo paradigma del derecho a la protección por desempleo de los trabajadores extranjeros irregulares: las SSTS de 18 de marzo, de 12 de noviembre y el anteproyecto de la ley de reforma de la LO 4/2000, de 19 de diciembre, de 2008", Aranzadi Social, Vol. 1, n 21, 2009.

Urteaga, Eguizki: "Las rentas mínimas en Francia", Papers: Revista de sociología, $\mathrm{n}^{\circ}$ 96, 3, 2011.

Valdés Dal-Ré, Fernando: "Las expulsiones colectivas de extranjeros: su tratamiento en el ordenamiento internacional y la jurisprudencia del TEDH", Derecho de las Relaciones Laborales, $\mathrm{n}^{\circ} 4$ de abril, 2018.

Valdueza Blanco, María Dolores: "Las situaciones administrativas de los extranjeros en España como condicionantes de los derechos socio-laborales", Relaciones Laborales, $\mathrm{n}^{\circ} 2,2003$.

Vela Díaz, Raquel: "La situación administrativa del trabajador/a extranjero y el derecho a la prestación por desempleo: visión desde una perspectiva de género", VI Encuentro Internacional de Investigadores en Derecho de Inmigración y Asilo, Valencia, 14 y 15 de junio de 2012. 
Von Ihering, Rudolf: El fin en el Derecho, Estudio Preliminar "El pensamiento jurídico de Ihering y la dimensión funcional del Derecho", a cargo de Monereo Pérez, J.L., Comares, Granada, 2011.

VV.AA., Izquierdo Escribano, Antonio (Coord)., El modelo de inmigración y los riesgos de exclusión, Madrid, Fundación Foessa, 2008.

VV.AA., Migración laboral internacional: un enfoque basado en los derechos, Ginebra, 2011.

VV. AA: "Pobreza y rentas mínimas en España y en la Unión Europea", publicado por la Confederación Sindicales de Comisiones Obreras. Secretaría de política Social, 2013. 